\title{
Natural food colouring with dye sorghum leaf sheaths
}

\author{
Folachodé U. G. Akogou
}




\section{Thesis committee}

\section{Promotor}

Prof. Dr V. Fogliano

Professor of Food Quality and Design

Wageningen University \& Research

\section{Co-promotors}

Dr A. R. Linnemann

Assistant professor, Food Quality and Design

Wageningen University \& Research

Dr H. M. W. den Besten

Associate professor, Laboratory of Food Microbiology

Wageningen University \& Research

Prof. Dr A. P. P. Kayodé

Professor, Laboratory of Valorization and Quality Management of Food Bio-Ingredients University of Abomey-Calavi, Benin

\section{Other members}

Dr I. D. Brouwer, Wageningen University \& Research

Prof. Dr C. Leeuwis, Wageningen University \& Research

Prof. Dr K. Raes, Ghent University, Belgium

Dr S. Birtic, Naturex R\&D, France

This research was conducted under the auspices of the Graduate School VLAG (Advanced Studies in Food Technology, Agrobiotechnology, Nutrition and Health Sciences) 


\title{
Natural food colouring with dye sorghum leaf sheaths
}

\author{
Folachodé U. G. Akogou
}

Thesis

submitted in fulfilment of the requirements for the degree of doctor

at Wageningen University

by the authority of the Rector Magnificus

Prof. Dr A. P. J. Mol,

in the presence of the

Thesis Committee appointed by the Academic Board

to be defended in public

on Wednesday 29 August 2018

at 8.30 am in the Aula. 
Folachodé U. G. Akogou

Natural food colouring with dye sorghum leaf sheaths, 160 pages.

$\mathrm{PhD}$ thesis, Wageningen University, Wageningen, the Netherlands (2018)

With references, with summary in English

ISBN: 978-94-6343-481-2

DOI: https://doi.org/10.18174/455839 
To the memory of Aimé Ayilara Akogou (1956-2010) 



\section{TABLE OF CONTENTS}

Chapter 1

General introduction

Chapter 2

Extraction methods and food uses of a natural red colorant from dye sorghum

Chapter 3

Antimicrobial evaluation of red, phytoalexin-rich sorghum food biocolorant

Chapter 4

Effects of processing and storage on the stability of the red biocolorant apigeninidin from sorghum

Chapter 5 105

Application of apigeninidin-rich red sorghum biocolorant in a fermented food improves product quality

Chapter 6

General discussion

Chapter 7

Summary

Acknowledgments

About the author 



\section{Chapter 1}





\section{SORGHUM: DESCRIPTION, POTENTIAL PROPERTIES AND USES}

Cereals represent the most important food crops and occupy more than 55\% of the arable land of the world (Simoni, 2009). Sorghum bicolor (L.) Moench is a well domesticated cereal used in Africa and Asia for animal feeding or as staple food (Ritter et al., 2007). The classification of sorghum is usually based on the agronomic traits or composition of a compound of interest (e.g. sugar or anthocyanins in the tissue) (Ritter et al., 2007). The morphology of the inflorescence is used to distinguish five races (i.e. bicolor, caudatum, durra, guinea and kafir) in the subspecies bicolor while the sugar composition in the stalks is used to distinguish grain sorghum and sweet sorghum (Ritter et al., 2007). In Benin, some varieties are specifically grown for their red pigments in the leaf sheaths (Figure 1). This allows to differentiate dye sorghum and non-dye sorghum (Kayodé et al., 2011). The polyphyletic origin of Sorghum bicolor spp. bicolor, the self-management and exchange of seed by farmers and the openpollination contributed to keep the sorghum varietal diversity alive in Africa (Ritter et al., 2007; Bezançon et al., 2009).

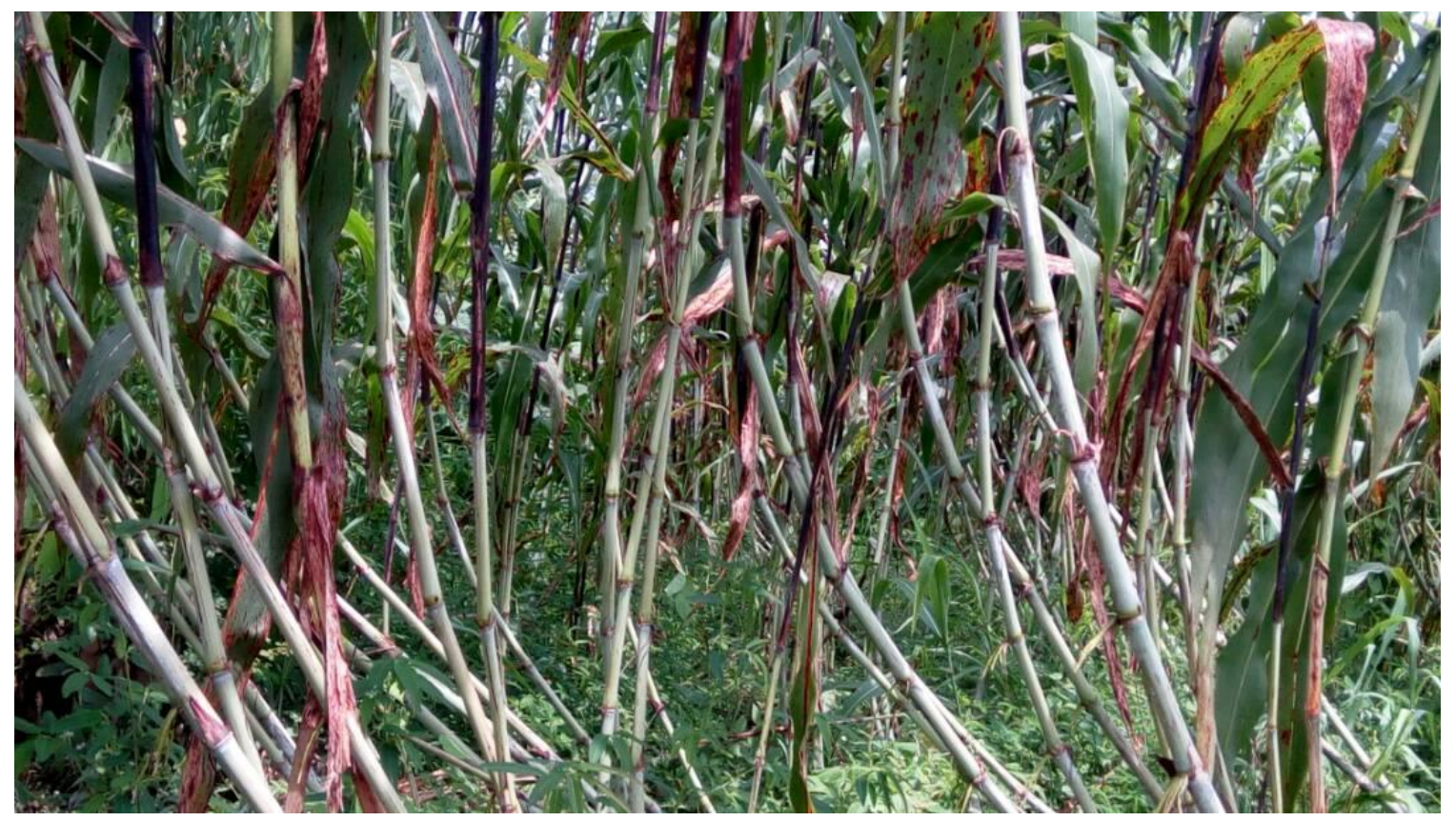

Figure 1. Sorghum plants grown for their pigmented leaf sheaths

Grain sorghum and sweet sorghum are mostly used as (a) staple food crops and (b) biofuel and feedstock, respectively (Vanamal et al., 2017). Valorisation of bioactive compounds from sorghum grain and biomass could bring added value to sorghum (Vanamal et al., 2017). In West Africa, for example, the leaf sheaths of dye sorghum are locally used as natural colorant (Kayodé et al., 2011). It is used to paint leather and calabashes or as food colorant (e.g. for 
porridge and local cheese) (Kayodé et al., 2011). Furthermore the extract from the leaf sheaths is rich in bioactive compounds (e.g. flavonoids, phenolic acids) (Kayodé et al., 2011). In general, sorghum bioactive compounds (phenolic acids, flavonoids, stilbenoids) possess antioxidant, anti-inflammatory, anti-proliferative (on cancer cells) activities and anti-cancer properties on human cells (Vanamal et al., 2017). The description of the leaf sheaths of the dye sorghum plant by Kayodé et al. (2011) indicate that dye sorghum leaf sheaths are the most promising part of the plant for the extraction of natural colorants with antioxidant properties as compared to the glume, the grain and the stem (Vanamal et al., 2017).

\section{FOOD APPLICATIONS OF SORGHUM BIOCOLORANT AND THEIR CONSUMPTION IN BENIN}

The most predominant cereal-based foods in Benin include thick porridge (called dibou), fermented porridge (koko), fermented malted beverage (sifanou), and slightly alcoholic beverages (tchoukoutou and tchapkalo) (Kayodé et al., 2005). Cowpea boiled alone (known as doungouri) or mixed with rice (named wake) are the main food uses of legumes (Madodé, 2012). In general, staple foods prepared with red varieties of cereals or legumes are well appreciated in West Africa for their sensorial attributes as well as the beliefs about the healthsupporting properties associated to their use (Kayodé et al., 2005; Madodé, 2012). For several reasons -e.g. scarcity of red sorghum during a certain period of the year, long cooking times and unsuitability of red cowpea to dehulling- food processors tend to switch from red sorghum and red cowpea to white maize and white cowpea, respectively (Kayodé et al., 2011; Madodé, 2012). In that case, it has been reported that apart from being used as an infusion to treat anaemia, the red colorant from dye sorghum leaf sheaths is commonly used as food colorant to obtain red foods when unpigmented varieties of cereals and legumes are used (Kayodé et al., 2011).

Sorghum bicolor is grown in the sudano-guinean and sudanian climate corresponding to the centre and the north of Benin (Fassinou Hotegni, 2014). An exploratory investigation in various communities of Benin (i.e. Dassa-Zoumè, Parakou and Natitingou) (Figure 2) provided an overview of the food applications of the extracts of the dye sorghum leaf sheaths in the growing areas of Sorghum bicolor in Benin. The foods dyed in Benin with dye sorghum extract are cereal, legume, tuber and milk-based foods (Table 1). Table 1 shows that sorghum biocolorant is traditionally used in food processing when a heat treatment and biological treatment (fermentation) are applied. Although the use of dye sorghum leaf sheaths for dyeing 
is a tradition that might be attributed to the habit and preference to consume red cereals and red legumes, its application has extended to other groups of foods such as tubers, soft cheese and soya bean curd. In addition to the sensorial quality changes, the application of the dye in tuber-based foods (chôkorou) and foods rich in protein (soft cheese and soya bean curd) are motivated by its ability (a) to facilitate digestion and prevent stomach-ache complaints after consuming chokkorou and (b) to prolong the shelf-life of soft cheese (wagashi) and soya bean curd (wagashisoja), respectively. Nevertheless, none of those beliefs are supported by scientific data.

Figure 3 presents the consumption of different groups of dyed foods in Benin. It reveals that koko and wagashi are the most dominant foods dyed in Benin. Koko and wagashi could hence be used as model foods to explore (a) the extraction of sorghum biocolorant and its stability during food processing and (b) the bioactive properties that sorghum biocolorant confers to fermented cereal foods and soft cheese. 


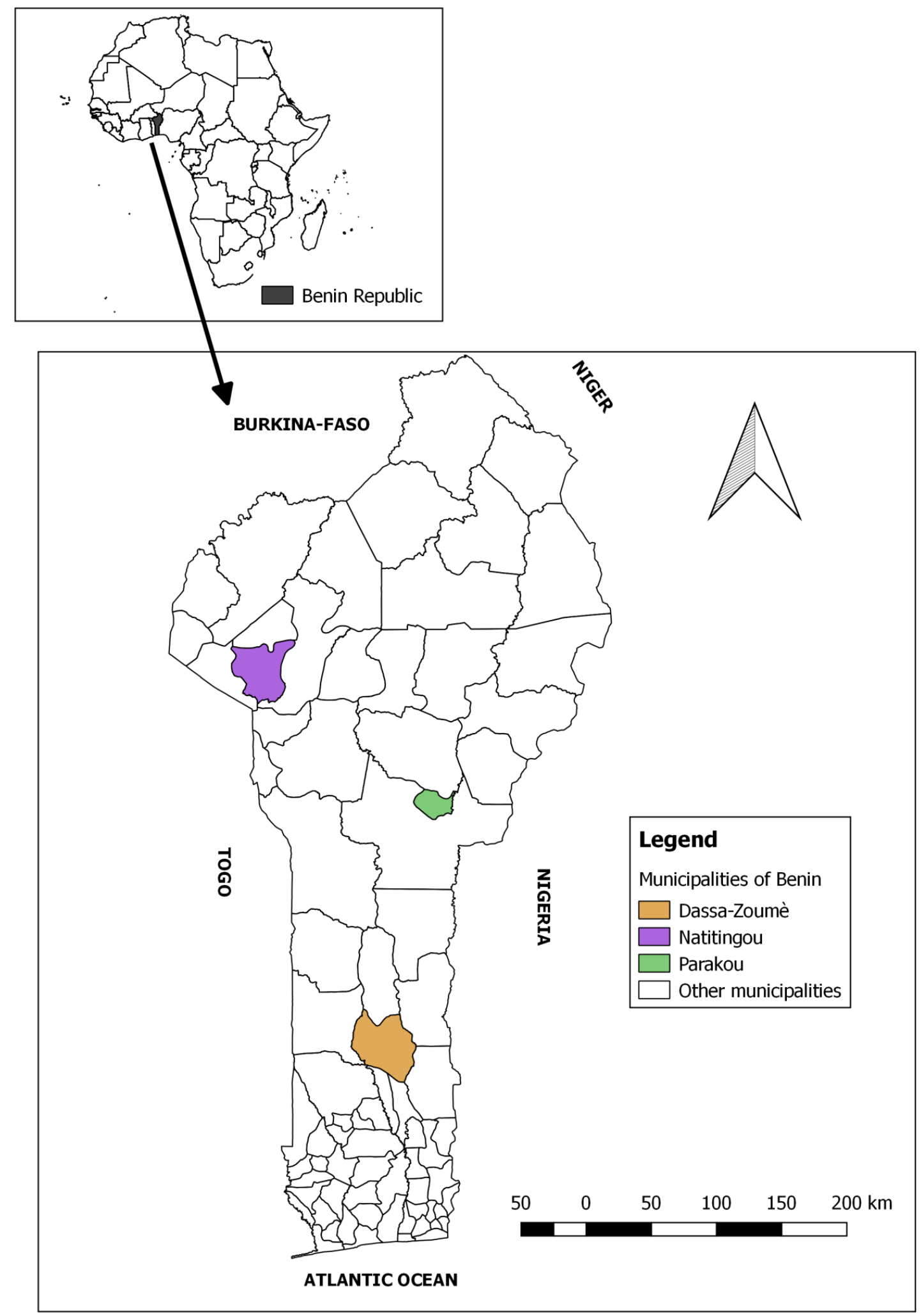

Figure 2. Map of Benin showing the communities probed for their food uses of dye sorghum leaf sheaths 
Table 1. Foods dyed with biocolorant extracted from dye sorghum leaf sheaths in Benin

\begin{tabular}{lllll}
\hline Food categories & Food name & Description & Main unit operations & Way of colorant application \\
\hline Non fermented & & & \\
cereal-based foods & & Maize thick porridge & Milling and cooking & Addition of colorant during \\
& Mon & Cooked rice & Cooking & cooking \\
\cline { 2 - 5 } & & & & Addition of colorant during \\
Fermented cereal- & Koko & Fermented porridge & Soaking, milling, fermentation & Milling with leaf sheaths or \\
based foods & & & and cooking & addition of colorant after \\
& & & fermentation \\
\cline { 2 - 5 } & Sifannou & Fermented beverage & Germination, fermentation and & Addition of colorant after \\
& & & cooking & fermentation \\
\cline { 2 - 5 } & Tchoukoutou & Fermented and & Soaking, germination, milling, & Addition of colorant after \\
& & alcoholic beverage & cooking, fermentation & fermentation \\
\cline { 2 - 5 } & Tchakpalo & Fermented sweet & Soaking, germination, cooking, & Addition of colorant after \\
& & alcoholic beverage & filtration, fermentation & fermentation \\
& & & &
\end{tabular}


Table 1. Continued

\begin{tabular}{lllll}
\hline Food categories & Food name & Description & Main unit operations & Way of colorant application \\
\hline Legume-based foods & Doungouri & Cooked cowpea & Cooking & Addition of colorant during \\
& & & & cooking \\
\cline { 2 - 5 } & Wagashisoja & Soya bean curd & Soaking, wet-milling, sieving, & Soaking in colorant after \\
& & & coagulation and moulding & moulding \\
\hline Cereal- and legume- & Waké & Prepared with & Cooking & Addition of colorant during \\
based foods & & doungouri and mon. & & cooking \\
\hline Tuber-based foods & Chôkourou & Pounded cooked yam & Cooking and pounding & Addition of colorant during \\
& & & & cooking \\
\hline Milk-based food & Wagashi & Traditional soft & Heating, coagulation and & Addition of colorant after \\
product & & cheese from cow & moulding & moulding
\end{tabular}




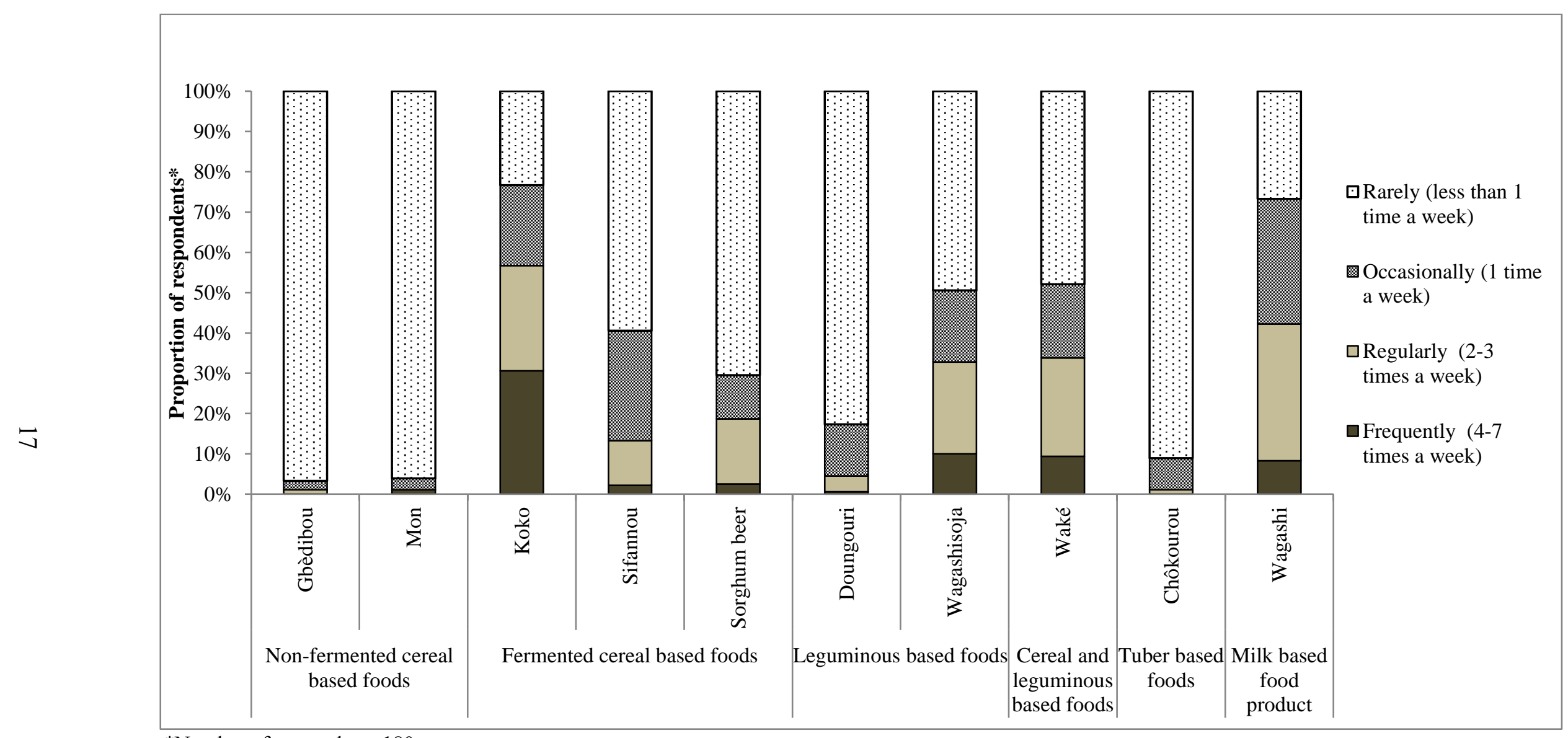

*Number of respondents 180

Figure 3. Frequency of consumption of foods dyed with sorghum biocolorant in Benin. 


\section{COLORANTS IN THE FOOD INDUSTRY AND THEIR STABILITY TO PROCESSING CONDITIONS}

The hue, the saturation and the lightness are colour attributes that contribute to the appealingness of food (Moore et al., 2005; Spence, 2016). Colour is a sensorial attribute that influences $62-90 \%$ of the product perception by consumers (Singh, 2006). It potentially impacts consumer expectation, the threshold of taste detection, flavour perception and consumer acceptance or liking (Moore et al., 2005; Spence, 2016). In general, food colorants are characterised by a chromophore, a group of atoms responsible for the colour and the auxochromes, the substituents lowering or intensifying the colour (Popli \& Patel, 2015). Food colorants can be classified according to their origin into synthetic and natural colorants (Burrows, 2009). Colorants derived from a chemical process are considered to be synthetic while natural ones are obtained from an extraction procedure (Burrows, 2009). Red synthetic colorants are classified in the categories of synthetic organic colorant (i.e. azo and non-azo colorant) and synthetic mineral colorant (iron oxide) (Wrolstad \& Culver, 2012; Feketea \& Tsabouri, 2017; Sigurdson et al., 2017). The red azo colorants are characterised by a chromophore with one or more azo bonds $(-\mathrm{N}=\mathrm{N}-$ ) (e.g. Allura red, Ponceau 4R and Amaranth) (Popli \& Patel, 2015; Feketea \& Tsabouri, 2017). On the contrary, the most known red non-azo colorant in food industry (Erythrosine) has a chromophore characterised by a carbonyl bond $(-\mathrm{C}=\mathrm{O})$ (Carmen Apostol et al., 2016; Feketea \& Tsabouri, 2017). Nowadays, consumer concerns about the potential risks of synthetic colorants on human health have increased the interest of the food industry in natural colorants (McCann et al., 2007; Stevens et al., 2014; Masone \& Chanforan, 2015). Most natural colorants are obtained from a watery extraction (Bechtold, 2014). The watery extract of a natural colorant consists of a mixture of compounds having a good affinity with water. The classification of natural colorants is commonly based on the properties of the most dominant compounds in the extract (Bechtold, 2014). Generally, red natural colorants are pigments extracted from insects (e.g. carmine), fungi (e.g. monascus pigment), algae (phycoerythrin) and plants (e.g. lycopene, betalains, carthamin and anthocyanins). These colorants have different applications in the food industry, depending on their chemical and functional properties (Wrolstad \& Culver, 2012; Bechtold, 2014; Anneville et al., 2015; Sigurdson et al., 2017).

Carminic acid is an anthraquinone extracted from the cochineal Dactylopius coccus Costa (Wrolstad \& Culver, 2012; Feketea \& Tsabouri, 2017). Its purple red colour and its stability to light and heat as well as its resistance to oxidation and $\mathrm{SO}_{2}$ are factors that support its use as 
colorant in food industry (Wrolstad \& Culver, 2012). Nevertheless, its use is still constrained by its insect-based origin (Tan et al., 2015) and its allergic concerns (Feketea \& Tsabouri, 2017). The red monascus pigment is produced by the fungal Monascus strains. Its instability to low $\mathrm{pH}(<5)$ and light are constraints limiting its application (Wrolstad \& Culver, 2012; Vendruscolo et al., 2016). Phycoerythrin is a red pigment extracted from red algae and marine unicellular cyanobacteria (Munier et al., 2014). Its low stability to heat (i.e. temperatures higher than $60^{\circ} \mathrm{C}$ ) and to light restrict its food applications (Munier et al., 2014).

Plant-based pigments are the most diverse group of red pigments. They comprise lycopene, the betalains, the carotenoids and the flavonoids (i.e. carthamin, anthocyanins). Lycopene is a red pigment extracted from fruits (orange, mango, pomegranate, papaya, watermelon, grapefruit, guava and tomato) and vegetables (carrot) (Kong et al., 2010). Although lycopene is recognized in the food industry as a food colorant with good antioxidant properties (Kong et al., 2010), its sensitivity to light, oxygen, high temperature, $\mathrm{pH}$, metal ions and catalysts limit its applications. Betalains are nitrogen-containing pigments with a pink colour (Sakuta, 2014). They are characterised by a chromophore (i.e. betalamic acid) conjugated with imino compounds or amino acids (Strack et al., 2003; Khan, 2016). Betalains are stable from acid to neutral $\mathrm{pH}$. However, sensitivity to heat and oxygen limits their application to products with a short shelf life (i.e. yoghurt, soft drinks and frozen desserts) (Obón et al., 2009; Wrolstad \& Culver, 2012; Khan, 2016). Carthamin belongs to the chalcone group of flavonoids commonly used as a food colorant in Japan (Wrolstad \& Culver, 2012). However, its watery extract is unstable to heat treatment, to acid and neutral $\mathrm{pH}$ as well as to light exposure (Fatahi et al., 2009; Dai et al., 2014). The anthocyanins are the main group of plant-based food colorants. The anthocyanin chromophore is composed by a chromane ring (Wallace \& Giusti, 2015). The auxochrome is an aromatic ring bound to the chromane ring by a carbon-carbon bond (Wallace \& Giusti, 2015). Hydroxylation or methoxylation of the auxochrome and the presence of sugar bound to the chromophore contribute to the diversity of the structure, colour and stability of anthocyanins to processing (Wrolstad \& Culver, 2012). In general, the majority of anthocyanins are (a) stable in acid conditions but degrade at neutral $\mathrm{pH}$ (Mojica et al., 2017) and (b) sensitive to temperature and light (Wrolstad \& Culver, 2012). Although the stability of anthocyanins is improved by glycosylation and acylation of the chromophore (Mojica et al., 2017), interest for groups of anthocyanins with increased stability in their nonglycosylated and non-acylated forms is increasing. Deoxyanthocyanidins are red anthocyanins without hydroxyl groups in their chromophore. Their good resistance to temperature, $\mathrm{pH}$ and $\mathrm{SO}_{2}$ are some properties that make them stand out (Awika et al., 2004; Ojwang \& Awika, 
2008; Yang et al., 2014). Contrary to the other anthocyanins that are meant to attract pollinators and seed disseminators (Stintzing \& Carle, 2004), 3-deoxyanthocyanidins are phytoalexins against the plant pathogens (Malathi et al., 2008). Their natural antimicrobial properties as phytoalexins might be used to inactive foodborne pathogens (Schutt \& Netzly, 1991; Stonecipher et al., 1993). These properties have been extended to anticarcinogenesis (Shih et al., 2007; Yang et al., 2009). Although 3-deoxyanthocyanidins have a narrow distribution as plant pigments in nature (Clifford, 2000), they are reported as abundant in dye sorghum leaf sheaths (Kayodé et al., 2011).

\section{THESIS OBJECTIVES}

The change of farming systems from a diverse cropping system towards an intense cultivation of cash crops (e.g. cotton) has led to a low prevalence of some cereals (i.e. sorghum and millet) as dietary staples in African sub-Saharan countries (Vom Brocke et al., 2014). In Benin, Sorghum bicolor is considered as a neglected and underutilised plant food (Dansi et al., 2012). The remarkable drought resistance of Sorghum bicolor in the context of climate change (Chivenge et al., 2015; Hadebe et al., 2017), the use of dye sorghum grain for food consumption (Kayodé et al., 2005) and the valorisation of its leaf sheaths as natural food colouring ingredients (Kayodé et al., 2011) rise the need to promote this neglected and underutilised crop to improve food security and provide an alternative source of income for households (Dansi et al., 2012). The main objective of this thesis is to study the extraction conditions of biocolorant from dye sorghum leaf sheaths, to evaluate its bioactive properties and its nutritional and sensorial impact on food products.

The specific objectives are:

- To evaluate the traditional extraction methods of sorghum biocolorant with emphasis on the technological and chemical considerations

- To assess the food preservative and antimicrobial properties of sorghum biocolorant using West African soft cheese (wagashi) as a food model

- To evaluate the stability of the sorghum biocolorant in relation to various food processing conditions

- To investigate the nutritional and sensorial effects of the sorghum biocolorant in a food product, in particular fermented maize dough. 


\section{THESIS OUTLINE}

A general introduction provides an overview of red food colorants, their importance in the food industry and the potential of dye sorghum as a food colorant. Chapter 2 presents (a) the traditional methods used in Benin to extract sorghum biocolorant from dye sorghum leaf sheaths, (b) the pigment composition according to the methods used, and (c) an illustration of the pigment in a food application. Chapter 3 (a) focuses on the current use of the sorghum biocolorant for soft cheese dyeing and (b) evaluates the preservative and antimicrobial activities of the pigments on the product. Chapter 4 presents the stability of apigeninidin, the main sorghum biocolorant pigment, to storage conditions (temperature and light) and to the most common food processing conditions (i.e. heat treatment, $\mathrm{pH}$ changes) in a watery extract as well as in maize porridge as an example of a food matrix. Chapter 5 (a) presents the influence of the addition of apigeninidin to maize dough on the nutritional and sensorial characteristics of the product and (b) elaborates on the interest to apply sorghum biocolorant to fermented foods. Chapter 6 discusses the main results of this thesis and their implications for the food industry. Recommendations are given for further research on sorghum biocolorant.

\section{REFERENCES}

Anneville, O., Domaizon, I., Kerimoglu, O., Rimet, F., \& Jacquet, S. (2015). Blue-green algae in a "Greenhouse Century"? New insights from field data on climate change impacts on cyanobacteria abundance. Ecosystems, 18 (3), 441-458.

Awika, J. M., Rooney, L. W., \& Waniska, R. D. (2004). Properties of 3-deoxyanthocyanins from sorghum. Journal of Agricultural and Food Chemistry, 52 (14), 4388-4394.

Bechtold, T., (2014). Colorant, Natural. In: Encyclopedia of Color Science and Technology, R. Luo, (Ed.). Springer New York, New York, NY: pp: 1-9.

Bezançon, G., Pham, J.-L., Deu, M., Vigouroux, Y., Sagnard, F., Mariac, C., Kapran, I., Mamadou, A., Gérard, B., \& Ndjeunga, J. (2009). Changes in the diversity and geographic distribution of cultivated millet (Pennisetum glaucum (L.) R. Br.) and sorghum (Sorghum bicolor (L.) Moench) varieties in Niger between 1976 and 2003. Genetic Resources and Crop Evolution, 56 (2), 223-236.

Burrows, J. (2009). Palette of our palates: a brief history of food coloring and its regulation. Comprehensive Reviews in Food Science and Food Safety, 8 (4), 394-408. 
Carmen Apostol, L., Ghinea, C., Alves, M., \& Gavrilescu, M. (2016). Removal of Erythrosine B dye from water effluents using crop waste pumpkin seed hulls as adsorbent. Desalination and Water Treatment, 57 (47), 22585-22608.

Chivenge, P., Mabhaudhi, T., Modi, A. T., \& Mafongoya, P. (2015). The potential role of neglected and underutilised crop species as future crops under water scarce conditions in SubSaharan Africa. International Journal of Environmental Research and Public Health, 12 (6), 5685-5711.

Clifford, M. N. (2000). Anthocyanins-nature, occurrence and dietary burden. Journal of the Science of Food and Agriculture, 80 (7), 1063-1072.

Dai, Y., Verpoorte, R., \& Choi, Y. H. (2014). Natural deep eutectic solvents providing enhanced stability of natural colorants from safflower (Carthamus tinctorius). Food Chemistry, 159, 116-121.

Dansi, A., Vodouhè, R., Azokpota, P., Yedomonhan, H., Assogba, P., Adjatin, A., Loko, Y., Dossou-Aminon, I., \& Akpagana, K. (2012). Diversity of the neglected and underutilized crop species of importance in Benin. The Scientific World Journal, 2012.

Fassinou Hotegni, V. N., 2014. Using agronomic tools to improve pineapple quality and its uniformity in Benin. Wageningen, The Netherlands: Wageningen University.

Fatahi, N., Carapetian, J., \& Heidari, R. (2009). Comparing stability of carthamin and safflower yellow pigments at $\mathrm{pH}$, temperature and light, from safflower (Carthamus tinctorius L.) florets. Research Journal of Biological Sciences, 4 (3), 250-253.

Feketea, G., \& Tsabouri, S. (2017). Common food colorants and allergic reactions in children: myth or reality? Food Chemistry.

Hadebe, S., Modi, A., \& Mabhaudhi, T. (2017). Drought Tolerance and Water Use of Cereal Crops: A Focus on Sorghum as a Food Security Crop in Sub-Saharan Africa. Journal of Agronomy and Crop Science, 203 (3), 177-191.

Kayodé, A. P. P., Adegbidi, A., Hounhouigan, J. D., Linnemann, A. R., \& Nout, M. J. R. (2005). Quality of farmers' varieties of sorghum and derived foods as perceived by consumers in Benin. Ecology of Food and Nutrition, 44 (4), 271-294.

Kayodé, A. P. P., Nout, M. J. R., Linnemann, A. R., Hounhouigan, J. D., Berghofer, E., \& Siebenhandl-Ehn, S. (2011). Uncommonly high levels of 3-deoxyanthocyanidins and antioxidant capacity in the leaf sheaths of dye sorghum. Journal of Agricultural and Food Chemistry, 59 (4), 1178-1184.

Khan, M. I. (2016). Stabilization of betalains: A review. Food Chemistry, 197, Part B, 12801285. 
Kong, K.-W., Khoo, H.-E., Prasad, K. N., Ismail, A., Tan, C.-P., \& Rajab, N. F. (2010). Revealing the power of the natural red pigment lycopene. Molecules, 15 (2), 959-987.

Madodé, Y. E., 2012. Keeping local foods on the menu: A study on the small-scale processing of cowpea. Wageningen, The Netherlands: Wageningen University.

Malathi, P., Viswanathan, R., Padmanaban, P., Mohanraj, D., Ganesh Kumar, V., \& Salin, K. (2008). Differential accumulation of 3-deoxyanthocyanidin phytoalexins in sugarcane varieties varying in red rot resistance in response to Colletotrichum falcatum infection. Sugar Tech, 10 (2), 154-157.

Masone, D., \& Chanforan, C. (2015). Study on the interaction of artificial and natural food colorants with human serum albumin: A computational point of view. Computational Biology and Chemistry, 56, 152-158.

McCann, D., Barrett, A., Cooper, A., Crumpler, D., Dalen, L., Grimshaw, K., Kitchin, E., Lok, K., Porteous, L., \& Prince, E. (2007). Food additives and hyperactive behaviour in 3-year-old and 8/9-year-old children in the community: a randomised, double-blinded, placebocontrolled trial. The Lancet, 370 (9598), 1560-1567.

Mojica, L., Berhow, M., \& de Mejia, E. G. (2017). Black bean anthocyanin-rich extracts as food colorants: Physicochemical stability and antidiabetes potential. Food Chemistry, 229, 628-639.

Moore, R. S., Stammerjohan, C. A., \& Coulter, R. A. (2005). Banner advertiser-web site context congruity and color effects on attention and attitudes. Journal of Advertising, 34 (2), 71-84.

Munier, M., Jubeau, S., Wijaya, A., Morançais, M., Dumay, J., Marchal, L., Jaouen, P., \& Fleurence, J. (2014). Physicochemical factors affecting the stability of two pigments: Rphycoerythrin of Grateloupia turuturu and B-phycoerythrin of Porphyridium cruentum. Food Chemistry, 150, 400-407.

Obón, J. M., Castellar, M. R., Alacid, M., \& Fernández-López, J. A. (2009). Production of a red-purple food colorant from Opuntia stricta fruits by spray drying and its application in food model systems. Journal of Food Engineering, 90 (4), 471-479.

Ojwang, L., \& Awika, J. M. (2008). Effect of pyruvic acid and ascorbic acid on stability of 3deoxyanthocyanidins. Journal of the Science of Food and Agriculture, 88 (11), 1987-1996.

Popli, S., \& Patel, U. D. (2015). Destruction of azo dyes by anaerobic-aerobic sequential biological treatment: a review. International Journal of Environmental Science and Technology, 12 (1), 405-420. 
Ritter, K. B., McIntyre, C. L., Godwin, I. D., Jordan, D. R., \& Chapman, S. C. (2007). An assessment of the genetic relationship between sweet and grain sorghums, within Sorghum bicolor ssp. bicolor (L.) Moench, using AFLP markers. Euphytica, 157 (1-2), 161-176.

Sakuta, M. (2014). Diversity in plant red pigments: anthocyanins and betacyanins. Plant Biotechnology Reports, 8 (1), 37-48.

Schutt, C., \& Netzly, D. (1991). Effect of apiforol and apigeninidin on growth of selected fungi. Journal of Chemical Ecology, 17 (11), 2261-2266.

Shih, C.-H., Siu, S.-O., Ng, R., Wong, E., Chiu, L. C., Chu, I. K., \& Lo, C. (2007). Quantitative analysis of anticancer 3-deoxyanthocyanidins in infected sorghum seedlings. Journal of Agricultural and Food Chemistry, 55 (2), 254-259.

Sigurdson, G. T., Tang, P., \& Giusti, M. M. (2017). Natural colorants: food colorants from natural sources. Annual Review of Food Science and Technology(0).

Simoni, S. (2009). World cereal production brief. Agricultural Management/Lucrari Stiintifice Seria I, Management Agricol, 11 (4).

Singh, S. (2006). Impact of color on marketing. Management Decision, 44 (6), 783-789.

Spence, C., (2016). The psychological effects of food colors. In: Handbook on Natural Pigments in Food and Beverages. Woodhead Publishing: pp: 29-58.

Stevens, L. J., Burgess, J. R., Stochelski, M. A., \& Kuczek, T. (2014). Amounts of artificial food colors in commonly consumed beverages and potential behavioral implications for consumption in children. Clinical Pediatrics, 53 (2), 133-140.

Stintzing, F. C., \& Carle, R. (2004). Functional properties of anthocyanins and betalains in plants, food, and in human nutrition. Trends in Food Science and Technology, 15 (1), 19-38.

Stonecipher, L. L., Hurley, P. S., \& Netzly, D. H. (1993). Effect of apigeninidin on the growth of selected bacteria. Journal of Chemical Ecology, 19 (5), 1021-1027.

Strack, D., Vogt, T., \& Schliemann, W. (2003). Recent advances in betalain research. Phytochemistry, 62 (3), 247-269.

Tan, H. S. G., Fischer, A. R., Tinchan, P., Stieger, M., Steenbekkers, L., \& van Trijp, H. C. (2015). Insects as food: exploring cultural exposure and individual experience as determinants of acceptance. Food Quality and Preference, 42, 78-89.

Vanamal, J. K., Massey, A. R., Pinnamaneni, s. R., Reddivari, L., \& Reardon, K. F. (2017). Grain and sweet sorghum (Sorghum bicolor L. Moench) serves as a novel source of bioactive compounds for human health. Critical Reviews in Food Science and Nutrition(just-accepted), 00-00. 
Vendruscolo, F., Schmidell, W., Moritz, D. E., Bühler, R. M. M., de Oliveira, D., \& Ninow, J. L. (2016). Isoelectric point of amino acid: importance for monascus pigment production. Biocatalysis and Agricultural Biotechnology, 5 (Supplement C), 179-185.

Vom Brocke, K., Trouche, G., Weltzien, E., Kondombo-Barro, C. P., Sidibé, A., Zougmore, R., \& Gozé, E. (2014). Helping farmers adapt to climate and cropping system change through increased access to sorghum genetic resources adapted to prevalent sorghum cropping systems in Burkina Faso. Experimental Agriculture, 50 (2), 284-305.

Wallace, T. C., \& Giusti, M. M. (2015). Anthocyanins. Advances in Nutrition: An International Review Journal, 6 (5), 620-622.

Wrolstad, R. E., \& Culver, C. A. (2012). Alternatives to those artificial FD\&C food colorants. Annual Review of Food Science and Technology, 3, 59-77.

Yang, L., Browning, J. D., \& Awika, J. M. (2009). Sorghum 3-deoxyanthocyanins possess strong phase II enzyme inducer activity and cancer cell growth inhibition properties. Journal of Agricultural and Food Chemistry, 57 (5), 1797-1804.

Yang, L., Dykes, L., \& Awika, J. M. (2014). Thermal stability of 3-deoxyanthocyanidin pigments. Food Chemistry, 160, 246-254. 


\section{Chapter 2}

\section{Extraction methods and food uses of a natural red colorant from}

\section{dye sorghum*}

F. U. G. Akogou, A. P. P. Kayodé, H. M. W. den Besten, A. R. Linnemann

*Published as: Akogou, F. U. G., Kayodé, A. P. P., den Besten, H. M. W., \& Linnemann, A. R. (2018). Extraction methods and food uses of a natural red colorant from dye sorghum. Journal of the Science of Food and Agriculture, 98, 361-368. 


\begin{abstract}
Background: The interest in stable natural colorants for food applications continues to grow. A red pigment extracted from the leaf sheaths of a sorghum variety (Sorghum bicolor) with a high content of apigeninidin is widely used as a biocolorant in processed foods in WestAfrica. This study compared the colour and the anthocyanin composition from traditional extraction methods to determine options for improvement and use of the red biocolorant from dye sorghum in the food sector.

Results: Sorghum biocolorant was commonly applied in fermented and heated foods. Traditional extraction methods predominantly differed in two aspects, namely the use of an alkaline rock salt (locally known as kanwu) and the temperature of the extraction water. Cool extraction using the alkaline ingredient was more efficient than hot alkaline and hot aqueous extractions in extracting anthocyanins. The apigeninidin content was three times higher in the cool and hot alkaline extracts than in the aqueous extract.
\end{abstract}

Conclusion: Cool and hot alkaline extraction at a $\mathrm{pH}$ of 8-9 were the most efficient methods for extracting apigeninidin from dye sorghum leaf sheaths. Broader use of the sorghum biocolorant in foods requires further research on its effects on the nutrient bioavailability and antioxidant activity.

Keywords: dye sorghum, extraction, 3-deoxyanthocyanidins, anthocyanins, apigeninidin, porridge. 


\section{INTRODUCTION}

Colour is important in consumer acceptance of food products (Chattopadhyay et al., 2008). Consumers are sensitive to food colour because it gives information on freshness, safety and sensory characteristics (Downham \& Collins, 2000; Chattopadhyay et al., 2008). Many consumers prefer natural colorants because of growing concerns about synthetic colorants (Chattopadhyay et al., 2008). Unfortunately, many natural colorants are not stable in their applications in food products (Wissgott \& Bortlik, 1996), for instance because they are sensitive to heat treatment. Therefore the dyeing industry is continuously looking for underutilised pigmented plants as new sources of stable colorants (Balole \& Legwaila, 2005). In West Africa, mature leaf sheaths harvested from dye sorghum (Sorghum bicolor) plants are used fresh or dried for food colouring purposes (Balole \& Legwaila, 2005). The red pigment extracted from dye sorghum leaf sheaths is a rich source of 3-deoxyanthocyanidins (Kayodé et al., 2011), a rare class of natural pigments (Awika \& Rooney, 2004). As most anthocyanins, the 3-deoxyanthocyanidins have an aglycon as base structure, which is bound to sugar moieties, or hydroxyl and methoxyl groups (Wallace \& Giusti, 2015). The absence of a hydroxyl group at the C-3 position of the aglycon is the main structural difference between 3deoxyanthocyanidins and common anthocyanins (Awika, 2008). Extracts of 3deoxyanthocyanidins are characterised by (a) a good stability to acidulants and $\mathrm{pH}$ changes (Awika et al., 2004; Ojwang \& Awika, 2008), (b) resistance of their dimeric forms (i.e. the apigeninidin-flavene dimer and the apigenin-7-O-methylflavene dimer) to nucleophilic and hydrophilic attacks by sulphite (Geera et al., 2012), (c) improved colour stability in the presence of co-pigments (Awika, 2008), (d) slow chalcone formation and ring opening when exposed to heat treatments (Yang et al., 2014), and (e) their antioxidant activity (Kayodé et al., 2011). Consequently, extracts from dye sorghum leaf sheaths could be a potentially interesting source of a red colorant for food applications when the use of anthocyanins is restricted due to their instability in certain food processing conditions (e.g. with respect $\mathrm{pH}$, bleaching agents and temperature) (Sims \& Morris, 1984; Cevallos-Casals \& CisnerosZevallos, 2004; Geera et al., 2012).

The red watery extract from the sorghum leaf sheaths is obtained by trituration or boiling, with or without using an alkaline rock salt named kanwu, kanwa or trona in West Africa (Kayodé et al., 2012b). However, the specific conditions of the different extraction methods and the impact of these conditions on the characteristics of the obtained extracts have not been studied. Kanwu is a mixture of carbonate and bicarbonate salts with sodium and potassium as 
monovalent ions and calcium, magnesium and iron as divalent ions (Madodé, 2012). In Benin, the applications of the watery extract of sorghum leaf sheaths include their use for decorative purposes (Downham \& Collins, 2000). Food applications of the biocolorant encompass its use in liquid foods like koko, a fermented cereal-based porridge, as well as in solid foods like wagashi, a West African soft cheese obtained by coagulating cow's milk with juice from Calotropis procera leaves (Aïssi et al., 2009; Kayodé et al., 2011; Kayodé et al., 2012a).

To date, no comparative data are available on how the biocolorant is traditionally extracted and how it is used for colouring foods. This study therefore evaluates local knowledge on the extraction methods of the colorant and its application in a model food that undergoes a sequence of processing steps, namely koko, followed by an analysis in the laboratory of the pigment profiles that result from different traditional extraction methods. The aim is to determine the extraction methods that are currently being used and compare the anthocyanin profile and colour characteristics of the dye extracts obtained by these methods with a view to improve the extraction and to assess the potential applications of sorghum biocolorant in the industrial food sector in developed countries.

\section{MATERIALS AND METHODS}

\section{Field survey}

\section{Study area}

The study was carried out in three towns of Benin, i.e. Parakou (latitude $9^{0} 15^{\prime} \mathrm{N}-9^{0} 29^{\prime} \mathrm{N}$, longitude $2^{\circ} 26^{\prime} \mathrm{E}-2^{0} 44^{\prime} \mathrm{E}$ ) and Natitingou (latitude $10^{\circ} 10^{\prime} \mathrm{N}-10^{\circ} 26^{\prime} \mathrm{N}$, longitude $1^{0} 12^{\prime} \mathrm{E}-$ $1^{0} 31^{\prime} \mathrm{E}$ ), both in the northern part of Benin, and in Dassa-Zoumè (latitude $7^{0} 44^{\prime} \mathrm{N}-7^{0} 52^{\prime} \mathrm{N}$, longitude $2^{0} 3^{\prime} \mathrm{E}-2^{0} 15^{\prime} \mathrm{E}$ ), in the centre of the country. These communities were selected because dye sorghum is grown there and commonly used for food applications.

\section{Survey}

From the three communities (Parakou, Natitingou and Dassa-Zoumè), data on the extraction of dye sorghum biocolorants were collected from 180 processors of dyed foods. For the application of dye sorghum colorant in fermented foods, data were collected from 90 processors of dyed koko using a questionnaire including the unit processes and the ingredients needed to extract and apply the colorant in koko. The questionnaires were in the local 
languages and conducted by two experienced interviewers in each community. The interviewers were trained during a one-day session and test interviews were held to assure that the questionnaire was well understood and administered correctly. The processors were randomly chosen. They aged from 16 to 67 years and were only women, since in Benin women are the main actors in the food processing sector (Quisumbing et al., 1995).

\section{Physico-chemical analysis}

Samples from the field and their pre-treatment

Samples of dye sorghum leaf sheaths and dyed koko were bought on local markets of Parakou, Natitingou and Dassa-Zoumè, packed in an ice box and transported to the laboratory. The samples of dyed koko were dried at $50{ }^{\circ} \mathrm{C}$ for $24 \mathrm{~h}$ and ground into powder. Dried porridge powder was used to extract the phenolic compounds. The sample of dye sorghum leaf sheaths were ground using a miller (Coffee Bean and Spice Mill Grinder Model \#843, Moulinex) and the derived powder was used to extract the phenolic compounds.

\section{Experimental design}

The traditional methods to extract biocolorants from the leaf sheaths of dye sorghum were assessed for the total phenolic and anthocyanin contents, as well as for their colour parameters. All three extraction methods resulting from the survey were studied. These were cool alkaline extraction, hot alkaline extraction and hot aqueous extraction. Processors were chosen according to the method they used to extract the colorant from sorghum leaf sheaths. Another batch of dye sorghum leaf sheaths and one batch of kanwu were bought from a local market in Dassa-Zoumè. The mean values of the total phenol content (TPC) and the anthocyanin content (ACY) of this sample of dye sorghum leaf sheaths were $130.7 \mathrm{mg} \mathrm{g}^{-1}$ and $28.7 \mathrm{mg} \mathrm{g}^{-1}$, respectively. A quantity of $50 \mathrm{~g}$ of dye sorghum leaf sheaths was extracted by triplicate processors for each extraction scenario. Samples of watery extracts and residues of leaf sheaths after extraction were taken at different process steps and transported to the laboratory. The residues of leaf sheaths collected after extraction were dried at $50{ }^{\circ} \mathrm{C}$ for $24 \mathrm{~h}$, ground into powder. The TPC non-extracted $\left(\mathrm{TPC}_{\mathrm{ne}}\right)$ and the ACY non-extracted $(\mathrm{ACY}$ ne by the traditional extraction methods were determined by measuring the TPC and ACY contents of the residues of the leaf sheaths. The percentage of $\mathrm{TPC}_{\mathrm{ne}}\left(\% \mathrm{TPC}_{\mathrm{ne}}\right)$ and $\mathrm{ACY} \mathrm{Y}_{\mathrm{ne}}\left(\% \mathrm{ACY} \mathrm{Y}_{\mathrm{ne}}\right)$ were calculated with formula's (1) and (2).

$$
\% \mathrm{TPC}_{\mathrm{ne}}=\frac{\mathrm{TPC}_{\text {residues }}}{130.7} \times 100
$$


Where: \% $\mathrm{TPC}_{\mathrm{ne}}$ : the percentage of $\mathrm{TPC}$ non-extracted using the traditional method, $\mathrm{TPC}_{\text {residues }}\left(\mathrm{mg} \mathrm{g}^{-1}\right)$ : the TPC of the residues of dye sorghum leaf sheaths, $130.7\left(\mathrm{mg} \mathrm{g}^{-1}\right)$ : the TPC of the dye sorghum leaf sheaths.

$$
\% \mathrm{ACY}_{\mathrm{ne}}=\frac{\mathrm{ACY}_{\text {residues }}}{28.7} \times 100
$$

Where: \% ACY $\mathrm{Ae}_{\text {n }}$ the percentage of ACY non-extracted using the traditional method, $\mathrm{ACY}_{\text {residues }}\left(\mathrm{mg} \mathrm{g}^{-1}\right)$ : the ACY of the residues of dye sorghum leaf sheaths, $28.7\left(\mathrm{mg} \mathrm{g}^{-1}\right)$ : the ACY of the dye sorghum leaf sheaths.

The traditional extraction methods were reproduced in duplicate in the laboratory. The watery extracts were analysed for their apigeninidin and phenolic acids (4-hydroxybenzoic acid and $p$-coumaric acid) contents as well as for their total colour density (TCD). A control was used to evaluate the efficiency of pigment extraction when kanwu and a heating treatment were not applied.

\section{Determination of total phenolic, anthocyanin, apigeninidin contents and TCD}

The phenolic compounds were extracted from dried samples of leaf sheaths and dyed koko using the acidified methanolic $(\mathrm{HCl} / \mathrm{methanol})(1 \% \mathrm{v} / \mathrm{v})$ extraction procedure as described by Kayodé et al.(2011). All extracts were directly used to determine the TPC, ACY, apigeninidin and phenolic acid contents.

The TPC was measured by the modified Folin-Ciocalteu method of Singleton \& Rossi (1965) as described by Kayodé et al.(2012b). Gallic acid was used as standard. The results were expressed as milligrams of gallic acid equivalent per gram of sample dry matter (DM) for samples of leaf sheaths or milligrams of gallic acid equivalent per millilitre for the sorghum biocolorant.

The ACY was measured at $525 \mathrm{~nm}$ using the method described by Abdel-Aal and Hucl.(1999). The results were expressed as milligrams of cyanidin-3-glucoside equivalent per gram of sample dry matter (DM) for samples of leaf sheaths or micrograms of cyanidin-3glucoside equivalent per millilitre for the sorghum biocolorant.

The anthocyanin and phenolic acid composition were analysed by an Ultimate 3000 RS High Performance Liquid Chromatography (HPLC) system equipped with a Diode Array Detector DAD-3000 RS (Thermo Scientific Dionex) and a quaternary pump LPG- 3000 RS (Thermo Scientific Dionex). The extracts were mixed with formic acid (10\%) $(1: 1 \mathrm{v} / \mathrm{v})$ and filtered through $0.2 \mu \mathrm{m}$ RC filter. A Polaris $5 \mathrm{C} 18$-A column $(150 \times 4.6 \mathrm{~mm}$, Varian $)$ was used at 25 ${ }^{\circ} \mathrm{C}$. The flow rate was $1 \mathrm{~mL} \mathrm{~min}^{-1}$. The mobile phase consisted of (A) $10 \%$ formic acid in 
Milli-Q water and (B) methanol. The elution programme was $0-20$ min from 5\% B to $60 \% \mathrm{~B}$; 20-35 min, from $60 \% \mathrm{~B}$ to $100 \% \mathrm{~B} ; 25-30 \mathrm{~min}, 100 \% \mathrm{~B} ; 30-31 \mathrm{~min}, 100 \% \mathrm{~B}$ to $5 \% \mathrm{~B} ; 31-35$ min, 5\% B. UV-Vis spectra were recorded from 220-700 nm. Apigeninidin, 4-hydroxybenzoic acid and $p$-coumaric acid were monitored at 480, 260 and $280 \mathrm{~nm}$, respectively. Standards of apigeninidin (Extrasynthese, France), 4-hydroxybenzoic acid (Sigma Aldrich, Netherlands) and $p$-coumaric acid (Sigma Aldrich, Netherlands) allowed identification and quantification. The watery extracts of dye sorghum leaf sheaths $(1 \mathrm{~mL})$ were diluted by addition of demi water (14 mL) and used to measure TCD according to Turfan et al. (2011).

\section{Determination of the colour parameters and image of the extracts}

A volume of $12 \mathrm{~mL}$ of sorghum colorant was poured in a cylindrical glass cuvette with a 3.3 $\mathrm{cm}$ inner-diameter and $2.2 \mathrm{~cm}$ inner-height. The colour was measured on an extract of $1.4 \mathrm{~cm}$ height with a spectrocolorimeter (ColorFlex, HunterLab) (illuminant D 65) in reflective mode against a white background (Tanoue et al., 2004). The values of the lightness $\left(L^{*}\right)$, the redness index $\left(a^{*}\right)$ and the yellowness index $\left(b^{*}\right)$ were recorded. The hue angle $\left(h^{\circ}\right)$ and the chroma $\left(C^{*}\right)$ were calculated using the following formulas described by Castellar et al. (2006).

$$
\begin{aligned}
& C^{*}=\sqrt{\left[\left(a^{*}\right)^{2}+\left(b^{*}\right)^{2}\right]} \\
& h^{o}=\tan ^{-1}\left(\frac{b^{*}}{a^{*}}\right)
\end{aligned}
$$

In addition, the watery extracts and their dilutions were poured in $1 \mathrm{~cm}$ pathway cuvettes and their images were taken with a Olympus Stylus camera (SP-820UZ) in a cabin lightened by 4 lamps of 36 watt.

\section{Statistical analysis}

The data collected on the characterization of dye sorghum leaf sheaths, on the monitoring of the extraction method, on the TPC, the ACY, the TCD and the colour parameters $\left(L^{*}, a^{*}, b^{*}\right.$, $C^{*}$ and $h^{\circ}$ ) were analysed using SPSS 16.0. The difference between the extraction methods was analysed with (i) the one-way analysis (ANOVA) followed by post-hoc tests or, when then the normality tests failed, by (ii) Kruskal-Wallis and Mann-Whitney pair-wise tests. The survey data collected on the extraction methods and the applications of sorghum colorant were compiled using Sphinx Plus ${ }^{2}$ v.4.5 (Le Sphinx Développement, Chavanod, France) software for survey management. 


\section{RESULTS}

\section{Traditional extraction of pigments from dye sorghum leaf sheaths}

The dye sorghum pigments are traditionally extracted from the plant leaf sheaths using three methods, i.e. cool alkaline extraction, hot alkaline extraction and hot aqueous extraction (Figure 1). In all extraction scenarios, the dye extraction technique started by a manual trituration of the leaf sheaths in water at room temperature. The trituration time applied for 1 $\mathrm{kg}$ of leaf sheaths during a cool alkaline extraction was 2 hours, which was at least three times longer than the time needed for the hot extraction methods. In the alkaline extraction method, $k a n w u$ (an alkaline rock salt) was used during the trituration of the leaf sheaths. The role of the kanwu was to facilitate the extraction of the pigment from the sheaths. For $1 \mathrm{~kg}$ of leaf sheaths, 100 to $180 \mathrm{~g}$ of kanwu was used for cool alkaline extraction while 40 to $140 \mathrm{~g}$ of $k a n w u$ was used for hot alkaline extraction (Figure 1). During hot extraction, the mixture of water and triturated leaf sheaths was heated gradually on a wood fire to reach a temperature of $86^{\circ} \mathrm{C}$ at a heating speed of $0.05^{\circ} \mathrm{C} \mathrm{s}^{-1}$. When the processor considered the colour of the water red enough, the heating was stopped. The watery dye extract was then filtered with a sieve $(250 \mu \mathrm{m})$ to remove the plant residues and was ready for use.

\section{Characteristics of the dye sorghum leaf sheaths and their extracts}

The mean TPC and ACY in dye sorghum leaf sheaths from the local markets of the study areas were $82.6 \mathrm{mg} \mathrm{g}^{-1} \mathrm{DM}$ and $28.6 \mathrm{mg} \mathrm{g}^{-1} \mathrm{DM}$, respectively. Table 1 presents the TPC and the ACY in the watery extracts using different extraction methods as well as the $\mathrm{TPC}_{\mathrm{ne}}$ and $\mathrm{ACY}_{\mathrm{ne}}$, which were recovered from the leaf sheaths after extraction. Although TPC were similar in watery extracts $\left(0.2 \mathrm{mg} \mathrm{mL}^{-1}\right)$, the ACY was highest in cool alkaline extracts with $228.5 \mu \mathrm{g} \mathrm{mL}^{-1}$ (Table 1). The lowest ACY (43.9 $\mu \mathrm{g} \mathrm{mL}^{-1}$ ) was measured in hot aqueous extracts. This quantity was 4 to 6 times higher than the concentration of anthocyanins in the extracts from the other extraction methods. After extraction, no differences between methods was observed on the $\mathrm{TPC}_{\mathrm{ne}}$ and $\mathrm{ACY}_{\mathrm{ne}}$ in the residues. Significant amounts of pigments (71.9\% of the TPC and $82.6 \%$ of ACY) remained in the leaf sheath residues. 


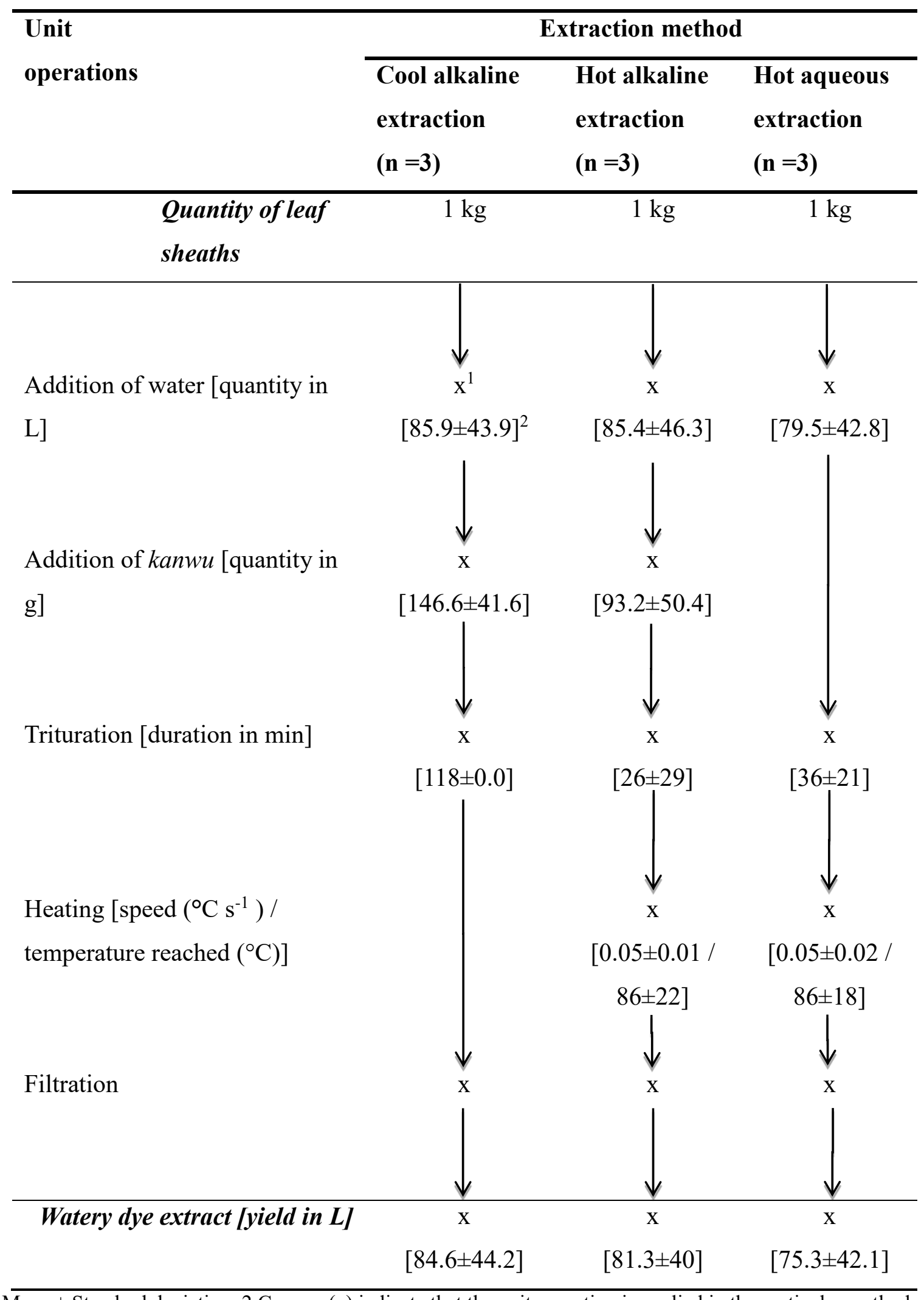

1 Mean \pm Standard deviation; 2 Crosses (x) indicate that the unit operation is applied in the particular method.

Figure 1. Process diagrams of three commonly used traditional extraction methods for biocolorants from dye sorghum leaf sheaths. 
Table 1. The phenolic content and anthocyanins in watery extracts and residues according to the three extraction method

\begin{tabular}{|c|c|c|c|c|}
\hline \multirow[t]{2}{*}{ Samples } & \multirow[t]{2}{*}{ Parameters $^{1}$} & \multicolumn{3}{|c|}{ Extraction method } \\
\hline & & $\begin{array}{l}\text { Cool alkaline } \\
\text { extraction } \\
(n=3)\end{array}$ & $\begin{array}{l}\text { Hot alkaline } \\
\text { extraction } \\
(n=3)\end{array}$ & $\begin{array}{l}\text { Hot aqueous } \\
\text { extraction } \\
(n=3)\end{array}$ \\
\hline \multirow{2}{*}{ Extract } & TPC $\left(\mathrm{mg} \mathrm{mL}^{-1}\right)$ & $0.3 \pm 0.2 \mathrm{a}^{2}$ & $0.2 \pm 0.1 \mathrm{a}$ & $0.2 \pm 0.0 \mathrm{a}$ \\
\hline & $\operatorname{ACY}\left(\mu \mathrm{g} \mathrm{mL}^{-1}\right)$ & $228.5 \pm 93.6 \mathrm{a}$ & $50.9 \pm 5.0 \mathrm{~b}$ & $43.9 \pm 8.3 \mathrm{~b}$ \\
\hline \multirow{4}{*}{$\begin{array}{l}\text { Residues of } \\
\text { leaf sheaths }\end{array}$} & $\mathrm{TPC}_{\mathrm{ne}}\left(\mathrm{mg} \mathrm{g}^{-1} \mathrm{DM}\right)$ & $99.8 \pm 12.0 \mathrm{a}$ & $89.8 \pm 21.6 \mathrm{a}$ & $94.4 \pm 21.9 \mathrm{a}$ \\
\hline & $\% \mathrm{TPC}_{\mathrm{ne}}$ & $76.3 \pm 9.2 \mathrm{a}$ & $68.7 \pm 16.5 \mathrm{a}$ & $72.2 \pm 16.8 \mathrm{a}$ \\
\hline & $\mathrm{ACY}_{\mathrm{ne}}\left(\mathrm{mg} \mathrm{g}^{-1} \mathrm{DM}\right)$ & $22.6 \pm 1.84 \mathrm{a}$ & $20.3 \pm 4.0 \mathrm{a}$ & $22.6 \pm 1.8 \mathrm{a}$ \\
\hline & $\% \mathrm{ACY}_{\mathrm{ne}}$ & $85.9 \pm 6.9 \mathrm{a}$ & $77.7 \pm 15.3 \mathrm{a}$ & $84.2 \pm 6.6 \mathrm{a}$ \\
\hline
\end{tabular}

As can be seen in Table 2, the alkaline extraction methods were the best performing methods for apigeninidin extraction because up to $152 \mu \mathrm{g} \mathrm{mL}^{-1}$ of apigeninidin was found in the cool and hot alkaline extracts against $46.6 \mu \mathrm{g} \mathrm{mL}^{-1}$ in the hot aqueous extract. The $\mathrm{pH}$ of the alkaline extract was around 8-9 whereas it remained 7 in the non-alkaline extract and in the control. The heat treatment led to a significant reduction in the ACY in the hot alkaline extract (Table 1) while the apigeninidin content was not affected. A higher content of 4hydroxybenzoic acid was measured with hot alkaline extraction. The extraction methods did not affect the $p$-coumaric acid content. 
Table 2. Apigeninidin and phenolic acid contents of dye sorghum leaf sheath extracts obtained by traditional methods

\begin{tabular}{|c|c|c|c|c|}
\hline \multirow[t]{2}{*}{ Parameters } & \multicolumn{4}{|c|}{ Extraction method } \\
\hline & $\begin{array}{l}\text { Control }^{1} \\
(n=2)\end{array}$ & $\begin{array}{l}\text { Cool alkaline } \\
\text { extraction } \\
(n=2)\end{array}$ & $\begin{array}{l}\text { Hot alkaline } \\
\text { extraction } \\
(n=2)\end{array}$ & $\begin{array}{l}\text { Hot aqueous } \\
\text { extraction } \\
(n=2)\end{array}$ \\
\hline $\begin{array}{l}\text { Apigeninidin } \\
\left(\mu \mathrm{g} \mathrm{mL}^{-1}\right)\end{array}$ & $12.1 \pm 1.3 \mathrm{c}^{2}$ & $152.0 \pm 21.7 \mathrm{a}$ & $131.0 \pm 7.5 \mathrm{a}$ & $46.6 \pm 0.9 \mathrm{~b}$ \\
\hline $\begin{array}{l}\text { 4-hydroxybenzoic } \\
\text { acid }\left(\mu \mathrm{g} \mathrm{mL}^{-1}\right)\end{array}$ & $4.9 \pm 0.2 \mathrm{~b}$ & $5.1 \pm 0.1 \mathrm{~b}$ & $6.0 \pm 0.3 \mathrm{a}$ & $5.3 \pm 0.3 \mathrm{~b}$ \\
\hline $\begin{array}{l}p \text {-coumaric acid } \\
\left(\mu \mathrm{g} \mathrm{mL}^{-1}\right)\end{array}$ & $3.6 \pm 0.3 \mathrm{a}$ & $3.5 \pm 0.3 \mathrm{a}$ & $4.1 \pm 0.6 \mathrm{a}$ & $3.8 \pm 0.6 \mathrm{a}$ \\
\hline
\end{tabular}

1 Control = ratio leaf sheaths / water of 1:90 (w/v) without alkaline ingredient or heating. This ratio was the ratio leaf sheaths / water used by processors in Benin.

2 Mean \pm Standard deviation; values with the same letter in the line express significant difference at $5 \%$.

Table 3 presents the TCD and the colour of the watery extracts. The alkaline methods (cool alkaline and hot alkaline) had a higher TCD. This suggests that alkaline extraction results in a more intense colour. In addition, the application of a heat treatment did not affect the intensity of the colour of the hot alkaline extract. The hot aqueous extraction was the method with the lowest TCD. Nevertheless, this TCD was still better than the control. A thermal treatment provided better colouring properties than a non-thermal treatment when no extraction aid (like $k a n w u$ ) was used. In addition, Figure 2 illustrates (i) the higher colour intensity of the alkaline extraction methods and (ii) the lower colour intensity of the aqueous method compared to the control. The values recorded for $L^{*}, a^{*}$ and $b^{*}$ for the extraction methods were all lower than for the control. This revealed that the watery extracts were too concentrated for colour measurement. Figure 3 presents the chromaticity diagram of the diluted watery extracts. 


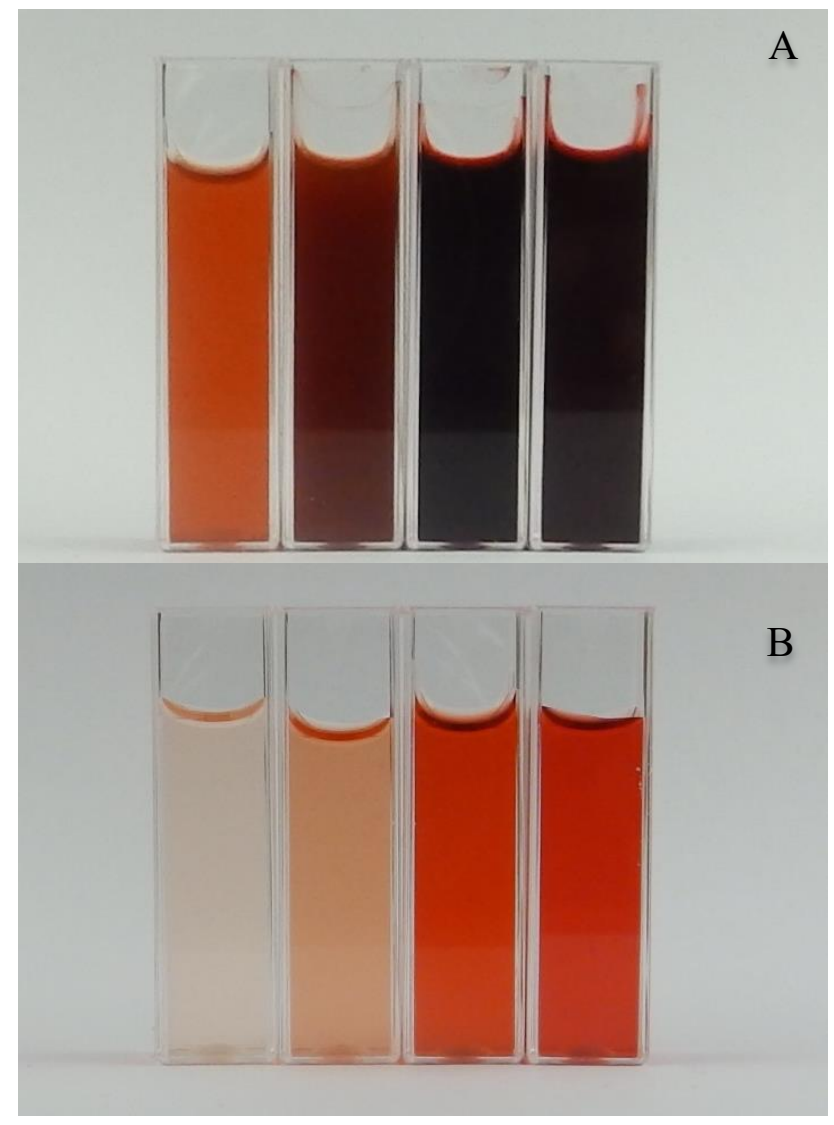

Figure 2. The images of the control, the hot aqueous extract, the hot alkaline extract and the cool alkaline extract (from the left to the right) (A) and their diluted samples (B) (dilution factor 0.07$)$.

To compare the watery extracts in a chroma range of 42-48, dilution factors of 0.25 and 0.07 were applied to (i) the hot aqueous extract and (ii) the hot alkaline and cool alkaline extracts, respectively. The dilution of the hot aqueous extract with a factor of 0.07 also increased the hue value. Furthermore, the colour parameters of the watery extracts from the hot and cool alkaline methods that were diluted with a factor of 0.07 were close on the chromaticity graph. Therefore, the heat treatment did not affect the colour of the alkaline watery extract. In general, the diluted watery extract from dye sorghum leaf sheaths had an orange-red colour. Cool alkaline extraction was preferred by the majority of the processors because of its good colouring properties and the ease of its application. The yield of extract from cool alkaline extraction was $84.6 \mathrm{~L} \mathrm{~kg}^{-1}$ of leaf sheaths (Figure 1). Indeed, the need of a heat treatment required for hot alkaline and hot aqueous extractions discouraged their use. Consequently, hot extractions are common in processing where a heat treatment of the food and dyeing need to be carried out simultaneously. 


\section{Application of sorghum biocolorant in starchy fermented foods: the case of}

\section{koko}

Maize-based koko is a porridge prepared from ogi, a fermented cereal slurry (Nago et al., 1998; Blandino et al., 2003). It is commonly dyed with sorghum biocolorant to give it a red colour (Kayodé et al., 2011). The dyeing could be performed before or after the fermentation step. Dyeing is applied after the fermentation step by $71 \%$ of the processors.

Table 3. The total colour density and the colour parameters of dye sorghum leaf sheaths extracts obtained by traditional methods

\begin{tabular}{lllll}
\hline Parameters $^{1}$ & \multicolumn{4}{c}{ Extraction method } \\
\cline { 2 - 5 } & $\begin{array}{l}\text { Control } \\
(\mathbf{n}=2)\end{array}$ & $\begin{array}{l}\text { Cool alkaline } \\
\text { extraction } \\
(\mathbf{n}=\mathbf{2})\end{array}$ & $\begin{array}{l}\text { Hot alkaline } \\
\text { extraction } \\
(\mathbf{n}=\mathbf{2})\end{array}$ & $\begin{array}{l}\text { Hot aqueous } \\
\text { extraction }(\mathbf{n}=2)\end{array}$ \\
\hline TCD & $4.6 \pm 0.0 \mathrm{c}^{2}$ & $48.9 \pm 0.4 \mathrm{a}$ & $50.6 \pm 0.0 \mathrm{a}$ & $15.5 \pm 0.1 \mathrm{~b}$ \\
$L^{*}$ & $12.0 \pm 0.8 \mathrm{a}$ & $0.5 \pm 0.2 \mathrm{c}$ & $0.7 \pm 0.1 \mathrm{c}$ & $10.2 \pm 0.6 \mathrm{~b}$ \\
$a^{*}$ & $28.8 \pm 0.2 \mathrm{a}$ & $1.5 \pm 0.1 \mathrm{c}$ & $1.8 \pm 0.1 \mathrm{c}$ & $19.8 \pm 0.5 \mathrm{~b}$ \\
$b^{*}$ & $17.8 \pm 0.3 \mathrm{a}$ & $-0.1 \pm 0.1 \mathrm{c}$ & $0.3 \pm 0.4 \mathrm{c}$ & $13.4 \pm 0.2 \mathrm{~b}$ \\
\hline
\end{tabular}

1 TCD: Total colour density; $L^{*}$ : Lightness index; $a^{*}$ : Redness index; $b^{*}$ : Yellowness index

2 Mean \pm Standard deviation; values with the same letter in the line express significant difference at $5 \%$.

Two methods were used by processors to produce dyed maize-based koko: one based on the use of the whole dye sorghum leaf sheaths and one based on the use of the watery extract of dye sorghum leaf sheaths. The use of the whole dye sorghum leaf sheaths in the processing of dyed koko was described by $29 \%$ of the processors. This method consisted of wet-grinding of maize with dye sorghum leaf sheaths. The wet flour thereby obtained had a colour similar to the red sorghum. This red flour was sieved and allowed to ferment spontaneously during 1 to 3 days at room temperature. The starchy sediment was then cooked to obtain dyed maizebased koko. This method was the only one in which the dye sorghum leaf sheaths underwent fermentation. This unit operation is efficient in depolymerisation of phenolic compounds, including anthocyanins, in the processing of koko (Kayodé et al., 2012a; Wiczkowski et al., 2015). Instead of using the whole leaf sheaths, the watery extract could also be used. In that case, maize grains were processed from the soaking to the fermentation step without adding 
dye sorghum leaf sheaths. When the fermentation was completed and the starchy sediment ready for cooking, a watery extract from dye sorghum leaf sheaths was produced using hot aqueous extraction (33\% of the processors) or cool alkaline extraction (38\% of the processors). This watery dye extract was added during cooking to obtain dyed koko.

The mean TPC of the samples of dyed koko varied from 0.26 to $1.23 \mathrm{mg} \mathrm{g}^{-1} \mathrm{DM}$ with a mean value of $0.64 \mathrm{mg} \mathrm{g}^{-1} \mathrm{DM}$ while the ACY varied from 0.1 to $1.0 \mathrm{mg} \mathrm{g}^{-1} \mathrm{DM}$ with a mean value of $0.23 \mathrm{mg} \mathrm{g}^{-1} \mathrm{DM}$.

\section{DISCUSSION}

The pigment profile of dye sorghum leaf sheaths found on the local market of the study areas resembled the data reported by Kayodé et al. (2011) who found a TPC of $95.5 \mathrm{mg} \mathrm{g}^{-1} \mathrm{DM}$ and an ACY of $27.1 \mathrm{mg} \mathrm{g}^{-1} \mathrm{DM}$. The results imply similar pigment profiles from samples from different study areas and from different seasons. Such stability of natural pigment profiles is not common because natural sources of food colorants are commonly characterised by substantial variations (Mapari et al., 2005).

The merit of the watery extraction methods is their selectivity for water soluble pigments like anthocyanins. However, overall the extraction of sorghum colorant using traditional methods resulted in low extraction rates, leaving the discarded plant residues still rich in pigments. Improvement and optimisation of the watery extraction methods are needed to increase the yield of this natural colorant. The use of leaf sheath powder could be the first improvement to the traditional methods. Indeed, particle size is crucial for a good extractability and could result in a lower amount of leaf sheaths needed (Brewer et al., 2014). In addition, low-cost and energy saving methods for sorghum biocolorant extraction could be designed by optimising $\mathrm{pH}$, temperature and time (Rajha et al., 2013). This could launch rural communities in Benin in an eco-friendly production of sorghum biocolorant for food industries. 


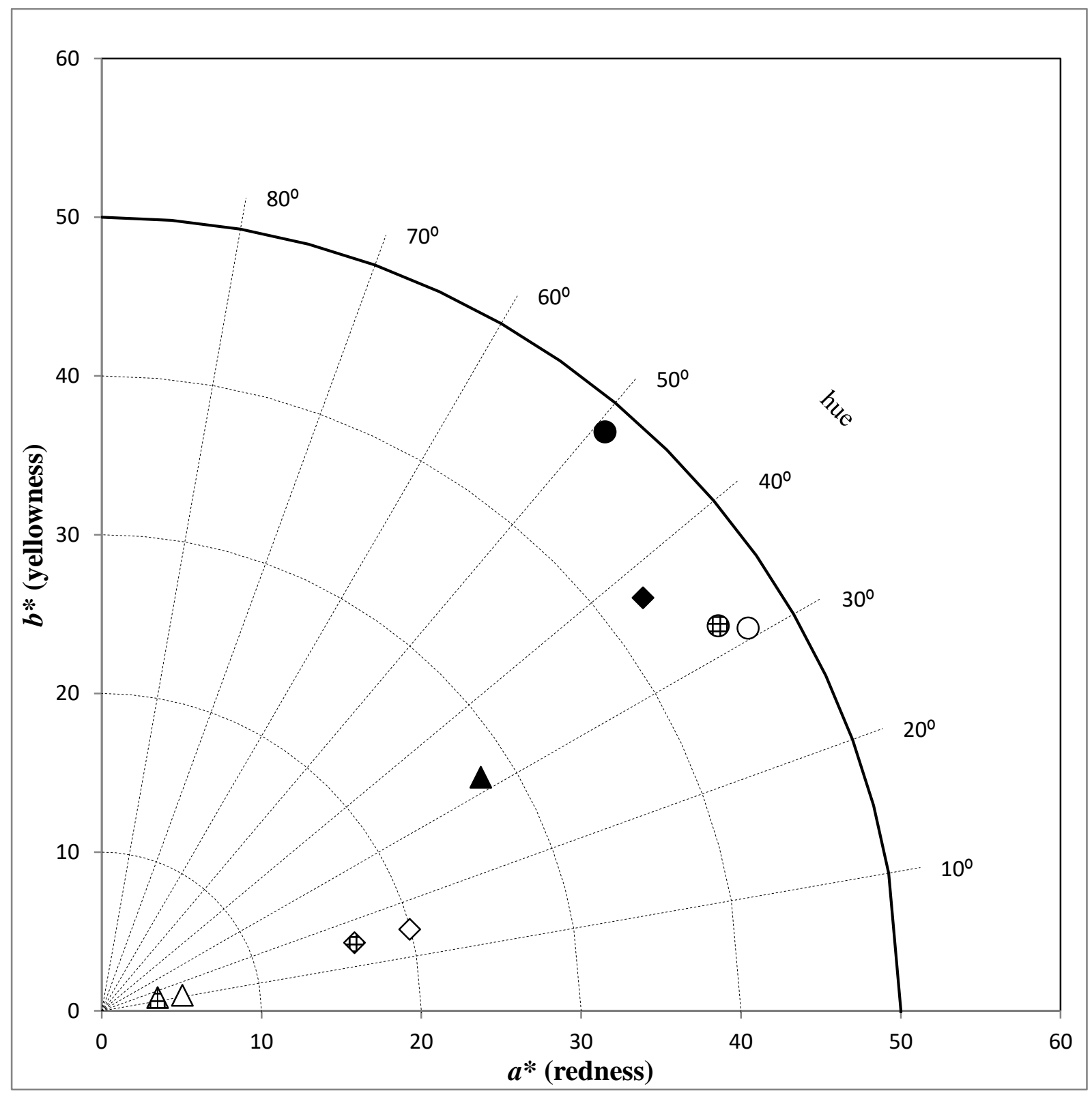

Figure 3. The chromaticity diagram of watery extract from hot aqueous (black), hot alkaline (tiled) and cool alkaline (white) with a dilution of factor 0.07 (circle), 0.25 (diamond) and 0.5 (triangle).

The application of a heat treatment temperature and a high $\mathrm{pH}$ affected the anthocyanin recovery during the hot aqueous and hot alkaline extraction process and could therefore explain the lower amount of anthocyanins measured in hot alkaline and aqueous extracts (Underhill \& Critchley, 1994; Kirca et al., 2007; Kayodé et al., 2012b). Alkaline extraction methods were efficient for obtaining apigeninidin because alkaline treatments promoted the release of bound phenolics present in the leaf sheaths (White et al., 2010). Significant 
amounts of apigeninidin were recovered in both cool and hot alkaline extracts at comparable levels. This finding provided additional information on the thermal stability of apigeninidin in the pH range 7-9 (Yang et al., 2014). The higher apigeninidin content in alkaline extracts (cool and hot) compared to the aqueous extract supports an uncommon response of apigeninidin to the alkaline treatment. In general, alkaline treatments cause degradation of anthocyanins with a loss of 25 to $35 \%$ of anthocyanin at pH 8 (Rodriguez-Saona et al., 1999), but in our study a higher apigeninidin content was measured in the alkaline extracts of dye sorghum as compared to the aqueous extract, indicating the stability of apigeninidin in a watery extract at alkaline conditions. The absence of hydroxyl on the third position of 3deoxyanthocyanidins (e.g. apigeninidin) could confer resistance to ring fission when a high pH and/or heat treatment are applied (Ojwang \& Awika, 2008; Yang et al., 2014). The stability of apigeninidin from alkaline extracts to food acidulants and to common food processing heat treatments (i.e. pasteurisation, cooking and sterilisation) still needs to be investigated further for its potential usability in foods.

The shade of the diluted watery extract of dye sorghum ( $h^{\circ}$ value between $\left.30-50\right)$ was less red than for commercial natural colorants such as elderberry $\left(h^{\circ}=17.2\right)$, red carrot concentrate $\left(h^{\circ}=15.5\right)$, red grape skin extract $\left(h^{\circ}=17.2\right)$ and hibiscus $\left(h^{\circ}=13.9\right)($ Castellar et al., 2006). Nevertheless, few natural colorants are known to possess an orange-red colour at high $\mathrm{pH}$ at high dilution factors (like the 0.07 in this research). This indicates a low dose response for the watery extract from dye sorghum leaf sheaths compared to other natural extracts (Castellar et al., 2006). In addition, the diluted watery extract of dye sorghum leaf sheaths had a hue value comparable to some synthetic food colorants (e.g. red allura, carmoisine, and ponceau 4R) that have a hue range value between 30-50 (Arocas et al., 2013). Sorghum biocolorant could therefore potentially replace those artificial colorants.

The data on the 4-hydroxybenzoic and $p$-coumaric acids provided information on the effect of the extraction method on two main groups of phenolic acids present in cereals (i.e. the hydroxybenzoic acids and hydroxycinnamic acids) (Wang et al., 2014). Our findings suggest that the amount of hydroxycinnamic acids (e.g. p-coumaric acid) in the extracts is comparable for the three extraction methods whereas the amount of hydroxybenzoic acids (e.g. 4hydroxybenzoic acid) could be increased by hot alkaline extraction. The effect of alkaline and non-alkaline extractions on the hydroxybenzoic acid and hydroxycinnamic acid contents still needs to be investigated further. 
Koko is a popular cereal-based food described as of low nutritional value for children (Kayodé et al., 2012a). It was selected as a model food because its processing involves fermentation and cooking. Fermentation potentially induces changes in the amount of phenolics, the antioxidant activity, the bioavailability of nutrients and the product $\mathrm{pH}$ (Katina et al., 2007; Kayodé et al., 2013; Wiczkowski et al., 2015). The mean TPC of sorghum-based koko found by Kayodé et al.(2012a) in Benin was $2.12 \mathrm{mg} \mathrm{g}^{-1}$ DM. Apparently the TPC of dyed maize-based koko was lower than the TPC of sorghum-based koko. A high amount of total reactive hydroxyls is measured in fermented foods using the method of Singleton and Rossi,(Singleton \& Rossi, 1965) possibly because of the hydrolysis of condensed phenols during the fermentation (Kayodé et al., 2007). The limited bioavailability of micronutrients such as iron and zinc in cereal-based infant foods is a major concern in transition countries like Benin (Mitchikpè et al., 2008; Tufts et al., 2015). In this respect, attention for the effects of sorghum colorant on the micronutrient bioavailability in infant foods is relevant. Consequently, future research is recommended on the bioavailability of micronutrients (e.g. the minerals iron and zinc) and antioxidant activity in dyed foods.

\section{CONCLUSION}

The natural colorant from dye sorghum leaf sheaths is rich in apigeninidin, which confers an orange-red colour to this extract. The extraction of this pigment is best in alkaline conditions. Future research on sorghum biocolorant should focus on the improvement of the traditional methods of pigment extraction, the stability of apigeninidin from alkaline extracts, the bioavailability of micronutrients like minerals (iron and zinc) and antioxidant activity in dyed foods.

\section{DECLARATION OF INTEREST}

The authors report no conflict of interest. This research was funded by Netherlands Fellowship Programmes (Grant award CF8188/2012). 


\section{ABBREVIATIONS USED}

ACY: anthocyanin;

DM: dry matter;

TPC: total phenolic content.

TCD: total colour density

\section{REFERENCES}

Abdel-Aal, E. S. M., \& Hucl, P. (1999). A rapid method for quantifying total anthocyanins in blue aleurone and purple pericarp wheats. Cereal Chemistry, 76 (3), 350-354.

Aïssi, V. M., Soumanou, M. M., Bankolè, H., Toukourou, F., \& de Souza, C. A. (2009). Evaluation of hygienic and mycological quality of local cheese marketed in Benin. Australian Journal of Basic Applied Sciences, 3 (3), 2397-2404.

Arocas, A., Varela, P., González-Miret, M. L., Salvador, A., Heredia, F., \& Fiszman, S. (2013). Differences in colour gamut obtained with three synthetic red food colourants compared with three natural ones: $\mathrm{pH}$ and heat stability. International Journal of Food Properties, 16 (4), 766-777.

Awika, J. M. (2008). Behavior of 3-deoxyanthocyanidins in the presence of phenolic copigments. Food Research International, 41 (5), 532-538.

Awika, J. M., \& Rooney, L. W. (2004). Sorghum phytochemicals and their potential impact on human health. Phytochemistry, 65, 1199-1221.

Awika, J. M., Rooney, L. W., \& Waniska, R. D. (2004). Properties of 3-deoxyanthocyanins from sorghum. Journal of Agricultural and Food Chemistry, 52 (14), 4388-4394.

Balole, T. V., \& Legwaila, G. M., (2005). Sorghum bicolor. In: Plant Resources of Tropical Africa 3. Dyes and tannins, P. C. M. Jansen and Cardon, D., (Eds.). PROTA Foundation, Wageningen, Netherlands/Backhuys Publishers, Leiden, Netherlands/CTA, Wageningen, Netherlands, Wageningen, Netherlands: pp: 146-155.

Blandino, A., Al-Aseeri, M. E., Pandiella, S. S., Cantero, D., \& Webb, C. (2003). Cerealbased fermented foods and beverages. Food Research International, 36 (6), 527-543.

Brewer, L. R., Kubola, J., Siriamornpun, S., Herald, T. J., \& Shi, Y. C. (2014). Wheat bran particle size influence on phytochemical extractability and antioxidant properties. Food Chemistry, 152, 483-490. 
Castellar, M. R., Obón, J. M., \& Fernández-López, J. A. (2006). The isolation and properties of a concentrated red-purple betacyanin food colourant from Opuntia stricta fruits. Journal of the Science of Food and Agriculture, 86 (1), 122-128. DOI 10.1002/jsfa.2285.

Cevallos-Casals, B. A., \& Cisneros-Zevallos, L. (2004). Stability of anthocyanin-based aqueous extracts of Andean purple corn and red-fleshed sweet potato compared to synthetic and natural colorants. Food Chemistry, 86 (1), 69-77.

Chattopadhyay, P., Chatterjee, S., \& Sen, S. K. (2008). Biotechnological potential of natural food grade biocolorants. African Journal of Biotechnology, 7 (17), 2972-2985.

Downham, A., \& Collins, P. (2000). Colouring our foods in the last and next millennium. International Journal of Food Science and Technology, 35 (1), 5-22.

Geera, B., Ojwang, L. O., \& Awika, J. M. (2012). New highly stable dimeric 3deoxyanthocyanidin pigments from Sorghum bicolor leaf sheath. Journal of Food Science, 77 (5), C566-C572.

Katina, K., Liukkonen, K.-H., Kaukovirta-Norja, A., Adlercreutz, H., Heinonen, S.-M., Lampi, A.-M., Pihlava, J.-M., \& Poutanen, K. (2007). Fermentation-induced changes in the nutritional value of native or germinated rye. Journal of Cereal Science, 46 (3), 348-355.

Kayodé, A. P. P., Akogou, F. U. G., Hounkpatin, W. A., \& Hounhouigan, J. D. (2012a). Effets des procédés de transformation sur la valeur nutritionnelle des formulations de bouillies de complément à base de sorgho. International Journal of Biological and Chemical Sciences, 6 (5), 2192-2201.

Kayodé, A. P. P., Bara, C. A., Dalodé-Vieira, G., Linnemann, A. R., \& Nout, M. J. R. (2012b). Extraction of antioxidant pigments from dye sorghum leaf sheaths. LWT-Food Science and Technology, 46 (1), 49-55.

Kayodé, A. P. P., Hounhouigan, J. D., \& Nout, M. J. R. (2007). Impact of brewing process operations on phytate, phenolic compounds and in vitro solubility of iron and zinc in opaque sorghum beer. LWT-Food Science and Technology, 40 (5), 834-841.

Kayodé, A. P. P., Mertz, C., Guyot, J. P., Brat, P., \& Mouquet-Rivier, C. (2013). Fate of phytochemicals during malting and fermentation of type III tannin sorghum and impact on product biofunctionality. Journal of Agricultural and Food Chemistry, 61 (8), 1935-1942.

Kayodé, A. P. P., Nout, M. J. R., Linnemann, A. R., Hounhouigan, J. D., Berghofer, E., \& Siebenhandl-Ehn, S. (2011). Uncommonly high levels of 3-deoxyanthocyanidins and antioxidant capacity in the leaf sheaths of dye sorghum. Journal of Agricultural and Food Chemistry, 59 (4), 1178-1184. 
Kirca, A., Özkan, M., \& Cemeroğlu, B. (2007). Effects of temperature, solid content and pH on the stability of black carrot anthocyanins. Food Chemistry, 101 (1), 212-218.

Madodé, Y. E. E., 2012. Keeping local foods on the menu: a study on the small-scale processing of cowpea. Wageningen, The Netherlands: Wageningen University.

Mapari, S. A. S., Nielsen, K. F., Larsen, T. O., Frisvad, J. C., Meyer, A. S., \& Thrane, U. (2005). Exploring fungal biodiversity for the production of water-soluble pigments as potential natural food colorants. Current Opinion in Biotechnology, 16 (2), 231-238.

Mitchikpè, E. C. S., Dossa, R. A. M., Ategbo, E.-A. D., van Raaij, J. M. A., Hulshof, P. J. M., \& Kok, F. J. (2008). The supply of bioavailable iron and zinc may be affected by phytate in Beninese children. Journal of Food Composition and Analysis, 21 (1), 17-25.

Nago, M. C., Hounhouigan, J. D., Akissoé, N., Zanou, E., \& Mestres, C. (1998). Characterization of the Beninese traditional ogi, a fermented maize slurry: physicochemical and microbiological aspects. International Journal of Food Science and Technology, 33 (3), 307-315.

Ojwang, L., \& Awika, J. M. (2008). Effect of pyruvic acid and ascorbic acid on stability of 3deoxyanthocyanidins. Journal of the Science of Food and Agriculture, 88 (11), 1987-1996.

Quisumbing, A. R., Brown, L. R., Feldstein, H. S., Haddad, L., \& Peña, C., 1995. Women: The key to food security. International Food Policy Research Institute Washington, DC.

Rajha, H. N., El Darra, N., Vorobiev, E., Louka, N., \& Maroun, R. G. (2013). An environment friendly, low-cost extraction process of phenolic compounds from grape byproducts. Optimization by multi-response surface methodology. Food and Nutrition Sciences, 4, 650659.

Rodriguez-Saona, L. E., Wrolstad, R. E., \& Pereira, C. (1999). Glycoalkaloid content and anthocyanin stability of alkaline treatment of red-fleshed potato extracts. Journal of Food Science, 64 (3), 445-450.

Sims, C. A., \& Morris, J. R. (1984). Effects of pH, sulfur dioxide, storage time, and temperature on the color and stability of red muscadine grape wine. American Journal of Enology and Viticulture, 35 (1), 35-39.

Singleton, V. L., \& Rossi, J. A. (1965). Colorimetry of total phenolics with phosphomolybdicphosphotungstic acid reagents. American Journal of Enology and Viticulture, 16 (3), 144-158. Tanoue, N., Soeno, K., Kawasaki, K., \& Atsuta, M. (2004). Influence of acidulated phosphate fluoride solution on the color stability of indirect composites. Journal of Prosthetic Dentistry, 92 (4), 343-347. 
Tufts, H. R., Harris, C. S., Bukania, Z. N., \& Johns, T. (2015). Antioxidant and antiInflammatory activities of kenyan leafy green vegetables, wild fruits, and medicinal plants with potential relevance for kwashiorkor. Evidence-Based Complementary and Alternative Medicine, 2015, 1-9.

Turfan, Ö., Türkyılmaz, M., Yemiş, O., \& Özkan, M. (2011). Anthocyanin and colour changes during processing of pomegranate (Punica granatum L., cv. Hicaznar) juice from sacs and whole fruit. Food Chemistry, 129 (4), 1644-1651.

Underhill, S., \& Critchley, C. (1994). Anthocyanin decolorisation and its role in lychee pericarp browning. Animal Production Science, 34 (1), 115-122.

Wallace, T. C., \& Giusti, M. M. (2015). Anthocyanins. Advances in Nutrition, 6 (5), 620-622.

Wang, T., He, F., \& Chen, G. (2014). Improving bioaccessibility and bioavailability of phenolic compounds in cereal grains through processing technologies: a concise review. Journal of Functional Foods, 7, 101-111.

White, B. L., Howard, L. R., \& Prior, R. L. (2010). Release of bound procyanidins from cranberry pomace by alkaline hydrolysis. Journal of Agricultural and Food Chemistry, 58 (13), 7572-7579.

Wiczkowski, W., Szawara-Nowak, D., \& Topolska, J. (2015). Changes in the content and composition of anthocyanins in red cabbage and its antioxidant capacity during fermentation, storage and stewing. Food Chemistry, 167, 115-123.

Wissgott, U., \& Bortlik, K. (1996). Prospects for new natural food colorants. Trends in Food Science \& Technology, 7 (9), 298-302.

Yang, L., Dykes, L., \& Awika, J. M. (2014). Thermal stability of 3-deoxyanthocyanidin pigments. Food Chemistry, 160, 246-254. 


\section{Chapter 3}

Antimicrobial evaluation of red, phytoalexin-rich sorghum food

\section{biocolorant*}

F. U. G. Akogou, H. M. W. den Besten, A. P. P. Kayodé, V. Fogliano, A. R. Linnemann

*Published as: Akogou, F. U. G., den Besten, H. M. W., Kayodé, A. P. P., Fogliano, V., \& Linnemann, A. R. (2018). Antimicrobial evaluation of red, phytoalexin-rich sorghum food biocolorant. PloS ONE, 13 (3), e0194657. 


\begin{abstract}
Sorghum (Sorghum bicolor) extract is traditionally used as red biocolorant in West Africa to colour foods, among which wagashi, a soft cheese. This biocolorant is a source of the phytoalexin apigeninidin and phenolic acids, and users claim that it has preservative effects next to its colouring properties. If such a claim can be scientifically substantiated, it adds a valuable functional property to this natural red colorant, thereby increasing its potential applications in the food industry. Hence, the present study evaluated the antimicrobial properties of dye sorghum extracts using challenge tests in broth and wagashi as a model of a popular food application. The alkaline extract and hot aqueous extract were used for dyeing wagashi by $87.7 \%$ and $12.3 \%$ of the traders, respectively. The dyeing procedure is perceived as a preservation strategy, and is also a means to maximise the revenues. However, results demonstrated that the application of sorghum biocolorant on wagashi had no inhibitory effect on the growth of fungi (Penicillium chrysogenum, Cladosporium macrocarpum) and Escherichia coli O157:H7. Furthermore, sorghum biocolorant in broth had no effect on growth of Listeria monocytogenes and Escherichia coli O157:H7. Consequently, the commonly used extracts for colouring soft West-African cheese did not show a preservative effect. In addition, dyeing did not affect the physico-chemical properties of wagashi. Still, the red colour hampered visual detection of microbial growth, thus clarifying the preservative effect reported by users.
\end{abstract}

Keywords: apigeninidin, wagashi, Penicillium chrysogenum, Cladosporium macrocarpum, Escherichia coli O157:H7, Listeria monocytogenes. 


\section{INTRODUCTION}

Nowadays consumers prefer natural food colorants because of potential adverse effects of artificial colorants, like hyperactivity in children (McCann et al., 2007; Stevens et al., 2014; Martins et al., 2016). However, the use of natural colorants is more challenging since they are usually less stable and more sensitive to processing conditions such as low $\mathrm{pH}$, high temperature and the characteristics of the food matrix in which they are applied (Wrolstad \& Culver, 2012). This is especially an issue for industrial applications because of the requirement to have a guaranteed shelf life during which the colour does not change in intensity or shade (Vegara et al., 2013).

Dye sorghum is a variety of sorghum (Sorghum bicolor) with characteristic dark red leaf sheaths, which is usually grown on the borders of crop fields in West Africa. These leaf sheaths are highly appreciated to extract a colouring agent as its application confers a stable bright red colour to foods (Akogou et al., 2018a; Akogou et al., 2018b). Extracts from dye sorghum leaf sheaths contain significant amounts of 3-deoxyanthocyanidins, namely apigeninidin and luteolinidin, as well as phenolic acids, i.e. 4-hydroxybenzoic acid and $p$ coumaric acid (Kayodé et al., 2011). Apigeninidin is a phenolic phytoalexin that plays a role in the defence mechanism of plants against pathogens and reportedly has preventive and antiproliferative properties against cancer (Shih et al., 2007; Yang et al., 2009; Poloni \& Schirawski, 2014). Phenolic acids (like 4-hydroxybenzoic acid and $p$-coumaric acid) are common weak acids used as preservative in the food industry (Stojković et al., 2013; Ling et al., 2015). Thus, the natural extract from dye sorghum leaf sheaths holds promise for wider food and pharmaceutical applications (Kil et al., 2009; Yang et al., 2009; Petti et al., 2014; Sousa et al., 2016).

Traditionally, dye sorghum extract has various applications in the West African region (Kayodé et al., 2011). It is used to colour soft cheese, locally known as wagashi, and porridges, which are a major staple food for its consumers. Wagashi is a traditional unripened soft cheese produced in Benin and Nigeria from cow's milk (Aworh \& Egounlety, 1985). Basically, the preparation of wagashi involves separation of the curd from the whey by the proteolytic activity of a watery extract of cysteine peptidases (i.e. procerain, procerain $\mathrm{B}$, CpCP-1, CpCP-2 and CpCP-3) from Calotropis procera (Dubey \& Jagannadham, 2003; Singh \& Dubey, 2011; Ramos et al., 2013). C. procera is the plant commonly used to provide the coagulant for making this type of soft cheese (Raheem et al., 2007; Cadmus et al., 2013). 
The curd of the cheese contains all the fat, and three quarters of the protein from the whole milk (Alalade \& Adeneye, 2006).

Wagashi has a short shelf-life of about three days in the Sudanian and Sudano-Guinean climatic zones, where it is mostly produced in Benin (Assogbadjo et al., 2005; Adetunji, 2008). Fungi (e.g. Penicillium and Cladosporium genera) and pathogens (e.g. Escherichia coli O157) contribute to spoilage and give rise to safety issues related to wagashi consumption (Aïssi et al., 2009). Soaking in whey or dyeing with sorghum colorant are some endogenous practices used, presumably also to increase shelf life (Alalade \& Adeneye, 2006; Cadmus et al., 2013). The inhibitory effect of apigeninidin on fungi and bacteria (Schutt \& Netzly, 1991; Stonecipher et al., 1993) suggests its potential as a food antimicrobial ingredient and as such could underpin the perception of users of its preservative effect. Nevertheless, data to substantiate the contribution of sorghum biocolorant to the presentation of African soft cheese are lacking. This study first evaluated the antimicrobial properties of the sorghum biocolorant in the laboratory, after which the current practices with respect to the production of wagashi in Benin were assessed.

\section{MATERIALS AND METHODS}

\section{Extraction of sorghum biocolorant}

Twenty five gram of dye sorghum leaf sheaths was weighed and washed with $0.5 \mathrm{~L}$ of demi water. Two litre of demi water was transferred into a bowl and heated to $90{ }^{\circ} \mathrm{C}$. The washed leaf sheaths were then added to the hot water and extracted for $10 \mathrm{~min}$. Next, the mixture was allowed to cool, after which the watery extract was obtained by centrifugation at $5000 \times \mathrm{g}$ during 15 min using a Heraeus instrument (Thermo Fisher Scientific, UK). The supernatant was filter-sterilised using a $0.2 \mu \mathrm{m}$ AcroVac Filter Unit (VWR, Netherlands) to obtain a sterile cool watery extract of sorghum biocolorant.

\section{Determination of the anthocyanin composition}

The apigeninidin, 4-hydroxybenzoic acid and p-coumaric acid contents of the sorghum biocolorant solutions were measured with an Ultimate 3000 RS High Performance Liquid Chromatography (HPLC) system equipped with a Diode Array Detector DAD-3000 RS (Thermo Scientific Dionex) and a quaternary pump LPG- 3000 RS (Thermo Scientific 
Dionex). The anthocyanins were separated with a Polaris C18-A column $(150 \times 4.6 \mathrm{~mm}$, Varian) at a flow rate of $1 \mathrm{~mL} \mathrm{~min}^{-1}$. The mobile phase consisted of formic acid $(10 \%)$ in milli-Q water (A) and methanol (100\%) (B). The total running time was 35 min and the elution gradient of B was planned as follows: 0 to $20 \mathrm{~min}$, from $5 \%$ to $60 \% \mathrm{~B} ; 20$ to $25 \mathrm{~min}$, from $60 \%$ to $100 \% \mathrm{~B} ; 25$ to $30 \mathrm{~min}$ with $100 \% \mathrm{~B} ; 30$ to $31 \mathrm{~min}$ from $100 \%$ to $5 \% \mathrm{~B} ; 31$ to 35 min with 5\% B. The UV-spectra were recorded at 190-610 $\mathrm{nm}$. The apigeninidin, 4hydroxybenzoic acid and p-coumaric acid were measured at 480, 260 and $280 \mathrm{~nm}$, respectively. Compounds were identified using the UV-spectra and the retention time of their corresponding standards. The following standards were used: apigeninidin (Extrasynthese, France), 4-hydroxybenzoic acid (Sigma Aldrich, Netherlands) and p-coumaric acid (Sigma Aldrich, Netherlands).

\section{Wagashi making in the laboratory}

Wagashi was made using a thermomixer (Vorwerk, Germany) in accordance to the common cheese making practices in Benin (Figure 1). Two litres of fresh full milk were transferred into the bowl of the thermomixer and heated at $60^{\circ} \mathrm{C}$ for $30 \mathrm{~min}$. Meanwhile, $35 \mathrm{~g}$ of Calotropis procera leaves, which were naturally grown in Benin and kept frozen at $-20^{\circ} \mathrm{C}$ until needed, was crushed using a mortar. A volume of $50 \mathrm{~mL}$ of fresh milk was added to the crushed leaves to extract the coagulating cysteine peptidases. This extract was then filtered with a sieve $(0.355 \mathrm{~mm})$ to remove the $C$. procera residues, and added to the warm milk and stirred at 40 $\mathrm{rpm}$. Next the temperature was raised to $80^{\circ} \mathrm{C}$. When the clotting started after 20 to $25 \mathrm{~min}$, the temperature was increased further to $90^{\circ} \mathrm{C}$ for $3 \mathrm{~min}$ to facilitate the expulsion of the whey. Next the curd was poured in sterilised stainless steel rings with a $44 \mathrm{~mm}$ inner-diameter and placed on a sterilised flame-tamer. The curd was left for one hour to allow the whey to drain. Finally the rings were removed, giving a cylindrical wagashi shape with a diameter of $44 \mathrm{~mm}$ and a height of $13 \mathrm{~mm}$. 


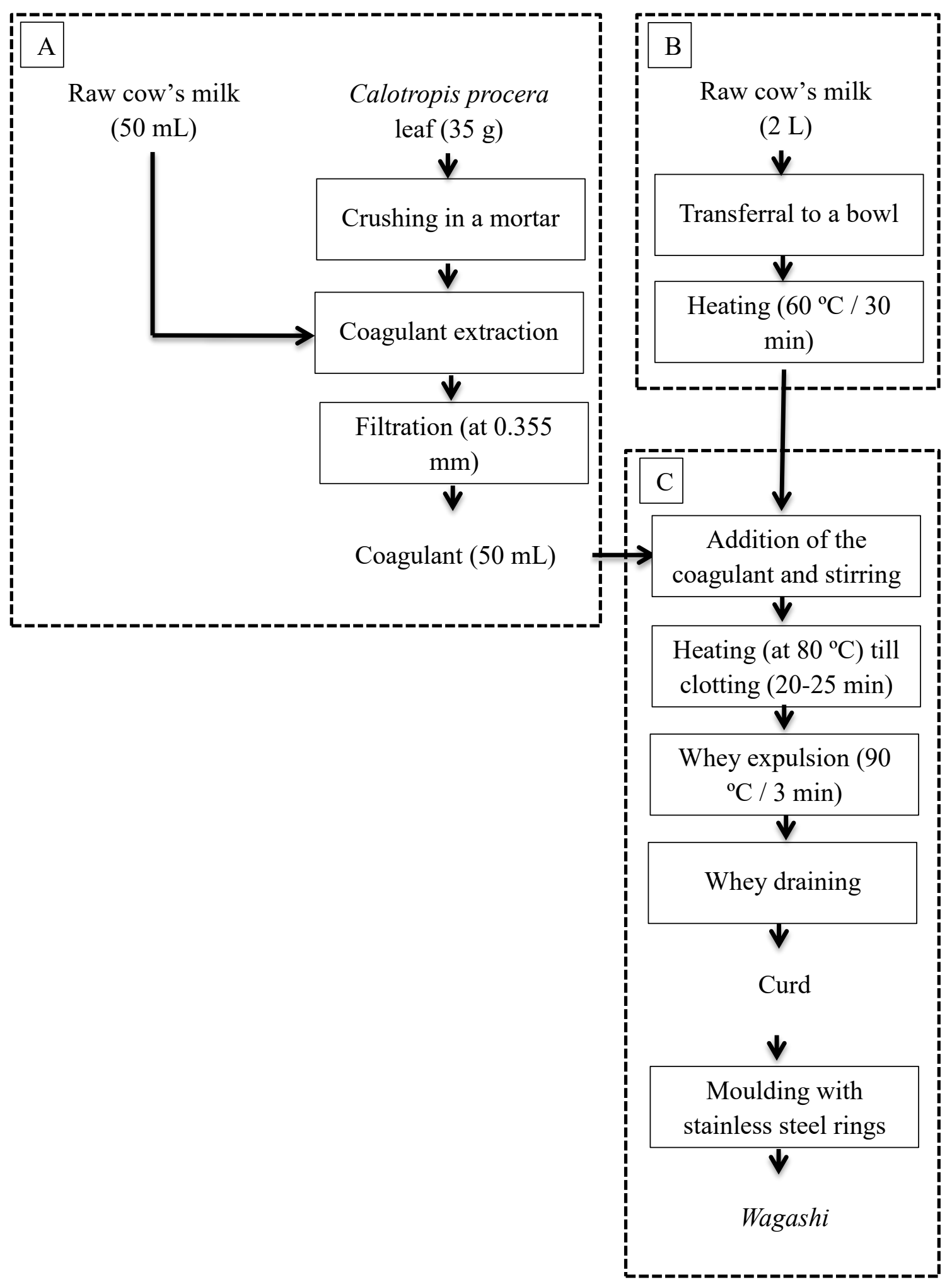

Figure 1. Flow chart of the coagulant extraction (A), the pre-treatment of the milk (B) and the clotting (C) in wagashi processing. 


\section{Application of sorghum biocolorant on wagashi}

The wagashi was dyed by soaking three cheese samples for 15 min either in sterile cool watery extract or in sterile hot watery extract of $60{ }^{\circ} \mathrm{C}$, obtained by warming sterile cool watery extract using a microwave (Panasonic 1670). Control samples were prepared by soaking cheese samples in demi water (negative control) or in a $0.1 \%$ solution of benzoic acid (positive control), based on the recommendation of the U.S Food and Drug Administration (FDA) to use benzoic acid as a food preservative at a maximum concentration of $0.1 \%$ (FDA, 2016). The experiments for wagashi making and biocolorant extraction were performed in duplicate on different days. The Figure S1. presents samples of non-dyed and dyed wagashi.

\section{Extraction of sorghum biocolorant for the challenge tests in broth}

For the microbiological challenge tests in broth, concentrated extracts were used. These were prepared by adding $48 \mathrm{~g}$ of powder of dye sorghum leaf sheaths to either $0.5 \mathrm{~L}$ of demi water or $0.5 \mathrm{~L}$ of aqueous solution of kanwu, an alkaline rock salt that is often used in West Africa for food preparation, at $1.5 \mathrm{mg} \mathrm{mL}^{-1}$. The extraction was performed at room temperature during $30 \mathrm{~min}$ under magnetic agitation. The watery extract of sorghum dye was collected by filtration using Whatman quantitative filter paper, ashless, Grade $42(2.5 \mu \mathrm{m})$ and was then filter-sterilized using a $0.2 \mu \mathrm{m}$ AcroVac Filter Unit (VWR, Netherlands). The resulting sterile watery extracts were mixed in equal volumes with two times concentrated sterile Brain Heart Infusion (BHI) (Oxoid LTD, England) broth to obtain dyed BHI (50\%). The control was prepared by mixing, again in equal volumes, two times concentrated sterile BHI broth and sterile demi-water. 


\section{Inoculum preparation}

All the microbial strains used were provided by the Laboratory of Food Microbiology (Wageningen University, Netherlands). The fungal strains (i.e. Penicillium chrysogenum, Cladosporium macrocarpum) were received in 1988 from the Centraalbureau voor Schimmelcultures (CBS, Utrecht, the Netherlands). Only the strain code of Cladosporium macrocarpum (i.e. 175.62) was available. One loop-full from a 3-day old culture of Penicillium chrysogenum as well as from a Cladosporium macrocarpum culture were inoculated on Malt Extract Agar slant tubes and incubated at $28{ }^{\circ} \mathrm{C}$ (at $64 \%$ of humidity) for seven days. The spores were harvested by adding $9 \mathrm{~mL}$ of sterile peptone physiological salt solution (Tritium microbiologie, Netherlands) to the slant tubes and mixed with a vortex. The spore suspensions were collected and stored in cryovials with $30 \%$ of glycerol at $-80{ }^{\circ} \mathrm{C}$. Cryovials were thawed at $4{ }^{\circ} \mathrm{C}$ overnight before use. To determine the spore concentrations, a volume of $100 \mu \mathrm{L}$ of the spore inoculum was transferred to $0.9 \mathrm{~mL}$ of peptone physiological salt solution (Tritium microbiologie, Netherlands). From this first dilution, series of 10-fold dilutions were made. From the dilutions, $100 \mu \mathrm{L}$ of spore inoculum was spread on DichloranGlucose (DG 18) Agar Base (Oxoid LTD, England) plates and incubated at $25{ }^{\circ} \mathrm{C}$. The plate counts were determined after 24 and $48 \mathrm{~h}$. The concentration of the inocula of $P$. chrysogenum and of C. macrocarpum were $6.3 \log$ spores $\mathrm{mL}^{-1}$ and $5.6 \log$ spores $\mathrm{mL}^{-1}$, respectively. Serial decimal dilutions of the inocula in peptone physiological salt solution (Tritium microbiologie, Netherlands) were made to prepare $4.3 \log$ spores $\mathrm{mL}^{-1}$ and $4.6 \log$ spores $\mathrm{mL}^{-1}$ of $P$. chrysogenum and C. macrocarpum, respectively. These inocula and their dilutions were used for the challenge tests on wagashi.

Strains of Escherichia coli O157:H7 and Listeria monocytogenes were available in cryovials with $30 \%$ of glycerol at $-80{ }^{\circ} \mathrm{C}$. Before use, they were streaked on BHI agar plates and incubated overnight at $30{ }^{\circ} \mathrm{C}$ to obtain single colonies. One bacterial colony was transferred in BHI broth and incubated at $37{ }^{\circ} \mathrm{C}$ for $24 \mathrm{~h}$ to obtain an inoculum of $9 \log \mathrm{CFU} \mathrm{mL}{ }^{-1}$. Equal volumes of the inocula of five pathogenic E. coli $\mathrm{O} 157: \mathrm{H} 7$ strains isolated from sheep (1), bovine (1), human (2) and a reference strain (ATCC 43895) were mixed to obtain a cocktail of pathogenic E. coli $\mathrm{O} 157: \mathrm{H} 7$ to be used in the challenge tests on wagashi. Inocula of pathogenic E. coli $\mathrm{O} 157: \mathrm{H} 7$ (from bovine origin) and L. monocytogenes (isolated from Mexican soft cheese) were also used for the growth tests in BHI broth. 


\section{Microbiological challenge tests}

\section{Challenge test in broth}

For the challenge tests in media, inocula of E. coli O157:H7 and L. monocytogenes were diluted in test tubes of BHI (dyed and plain) in order to achieve an initial concentration of 5 $\log \mathrm{CFU} \mathrm{mL} \mathrm{m}^{-1}$. Inoculated tubes were incubated at $37^{\circ} \mathrm{C}$. Samples were taken at $0,1,2,4,6,8$ and $24 \mathrm{~h}$ for monitoring bacterial growth. The bacterial counts were determined by making decimal dilutions in peptone physiological salt solution (Tritium microbiologie, Netherlands) and plating on BHI agar plates. The experiment was performed in duplicate and reproduced on a different day using freshly prepared materials.

\section{Challenge test with wagashi}

The challenge tests with wagashi were performed in a climate chamber (Weiss Enet environmental simulation, Weiss Technik) at a temperature of $28{ }^{\circ} \mathrm{C}$ and relative humidity of 64\%. These conditions correspond to those in the north of Benin (Assogbadjo et al., 2005), where wagashi is mostly produced. Samples of wagashi were surface-inoculated with $2 \mu \mathrm{L}$ of $4.3 \log$ spores $\mathrm{mL}^{-1}$ and $6.3 \log$ spores $\mathrm{mL}^{-1}$ of P. chrysogenum, $2 \mu \mathrm{l}$ of $4.6 \log$ spores $\mathrm{mL}^{-1}$ and $5.6 \log$ spores $\mathrm{mL}^{-1}$ of C. macrocarpum and $5 \mu \mathrm{L}$ of $7.6 \log \mathrm{CFU} \mathrm{mL} \mathrm{m}^{-1}$ of the E. coli O157:H7 cocktail. Previous studies investigating the quality and the safety of West African soft cheese, highlighted that E. coli and L. monocytogenes are the most relevant foodborne pathogens of this dairy product (Aïssi et al., 2009; Adetunji \& Arigbede, 2011), with a lower prevalence for L. monocytogenes as compared to E. coli (Omemu et al., 2014; Saliu et al., 2014; Adeyeye \& Adeyeye, 2017). Therefore we focussed on E. coli 157:H7 in the application study on wagashi. The growing area on the wagashi was a circle with a diameter of $44 \mathrm{~mm}$ corresponding to a surface of $1519 \mathrm{~mm}^{2}$. Samples were incubated during 3 days. Three samples of wagashi inoculated with the E. coli cocktail were analysed at 0,5 , and $24 \mathrm{~h}$, respectively. At $72 \mathrm{~h}$, three samples inoculated with P. chrysogenum and C. macrocarpum were analysed. The growth of $E$. coli $\mathrm{O} 157: \mathrm{H} 7$ on wagashi was monitored by making a primary decimal dilution of each whole sample in peptone physiological salt solution (Tritium microbiologie, Netherlands) and homogenizing the sample using the stomacher, followed by a series of decimal dilutions in peptone physiological salt solution (Tritium microbiologie, Netherlands) and plate counting on Sorbital McConkey agar (Oxoid LTD, England). The growth of the fungal strains on wagashi was determined from pictures of the samples. The growth was assessed using ImageJ 1.46r, an open source Java-written program. The 
experiment was performed in triplicate and reproduced on a different day using freshly prepared wagashi, colorant extract, and freshly prepared microbial cultures.

\section{Physico-chemical parameters of wagashi}

The $\mathrm{pH}$, the dry matter and the acid value of wagashi were measured of two samples at 0 and $72 \mathrm{~h}$ for each replication. The $\mathrm{pH}$ of wagashi was measured using a $\mathrm{pH}$ meter (Phenomenal, Type pH100L, VWR). The dry matter was determined by drying samples at $100{ }^{\circ} \mathrm{C}$ during 24 $\mathrm{h}$ with a drying oven (VENTI-Line VL 115, VWR). The acid value was determined using the AFNOR norms as described by Bup et al. (2012). Briefly, a sample of wagashi (2 g) was weighted, crushed and dissolved in $50 \mathrm{~mL}$ of ethanol / diethyl ether (1/1). This mixture was homogenised during $5 \mathrm{~min}$. Three drops of indicator (1\% of phenolphthalein in ethanol) was added to the mixture and then titrated with $0.1 \mathrm{M} \mathrm{KOH}$ in ethanol until the end point of the indicator. The $\mathrm{pH}$ at the indicator end point in our samples was $9.5 \pm 0.2$. Data were expressed as $\mathrm{mg} \mathrm{KOH} \mathrm{g}{ }^{-1}$ of sample dry matter (DM).

The acid value was calculated using the following formula (1):

Acid Value $=\frac{56.1 \times \mathrm{N} \times \mathrm{V}}{\mathrm{M}}$

in which

56.1: Molecular mass in $\mathrm{g}$ of $\mathrm{KOH}$

$\mathrm{N}$ : Normality of $\mathrm{KOH}$

$\mathrm{V}$ : Volume in $\mathrm{mL}$ of $\mathrm{KOH}$

M: mass in $g$ of sample in dry matter.

\section{Survey on the application of sorghum biocolorant on wagashi}

A study was carried out to assess the traditional application methods of sorghum biocolorant and the perceptions associated to its use in three towns with a rich tradition in the production of dyed wagashi in Benin, Africa, i.e. Parakou (in Borgou department), Natitingou (in Atacora department) and in Dassa-Zoumè (in Collines department). In each town, 30 traders were interviewed. Data were collected using a questionnaire, which was administered in the local language after an one-day training. It contained questions about ethnicity, unit operations and ingredients used to produce dyed wagashi, the revenues generated from dyed and non-dyed wagashi and the reasons for dyeing wagashi. The increase in revenues $\left(\mathrm{R}_{\mathrm{i}}\right)$ due to dyeing of wagashi were calculated using formula (2). The respondents were selected from the main cheese market in each locality. The protocols used for data collection were approved by the 
Faculty of Agricultural Sciences of the University of Abomey-Calavi, Benin. Informed consent was obtained from all respondents.

$$
\mathrm{R}_{\mathrm{i}}(\%)=\frac{\mathrm{R}_{\text {dyed }}-\mathrm{R}_{\text {non-dyed }}}{\mathrm{R}_{\text {non-dyed }}} \times 100
$$

where:

$\mathrm{R}_{\mathrm{i}}=$ increase in revenues

$\mathrm{R}_{\text {dyed }}=$ revenues from dyed wagashi

$\mathrm{R}_{\text {non-dyed }}=$ revenues from non-dyed wagashi

\section{Data analysis}

The field survey data were compiled using Sphinx Plus ${ }^{2}$ v.4.5 (Le Sphinx Développement, Chavanod, France) software for survey management. The mean values of the areas of fungal growth, the bacterial counts, the dry matter, the $\mathrm{pH}$ and the acid values were calculated and the difference between dyed samples and the controls were evaluated by (a) one-way analysis (ANOVA) followed by Turkey's post-hoc tests or (b) by Kruskal-Wallis and Mann-Whitney pair-wise tests if normality tests failed.

\section{RESULTS}

Effects of sorghum biocolorant on the microbial and physico-chemical quality of wagashi

Figure 2 presents the growth of E. coli O157:H7 and L. monocytogenes in dyed and non-dyed BHI. A dyed BHI with a final concentration of apigeninidin, 4-hydroxybenzoic acid and $p$ coumaric acid of 23.5, 6.8 and $3.95 \mu \mathrm{g} \mathrm{mL}^{-1}$, respectively, did not affect the growth of pathogens (i.e. L. monocytogenes and E. coli O157:H7) in suspension (Figs 2a and 2b). Figure 3 presents the growth of L. monocytogenes at a 3.2 times higher concentration of apigeninidin. As most phenolic plant extracts usually have a less pronounced activity against Gram positive bacteria (e.g. L. monocytogenes) as compared to Gram negative bacteria (e.g. E. coli) (Nostro et al., 2000; Butkhup et al., 2016), the test focused only on L. monocytogenes. The use of dyed BHI with a higher apigeninidin content (namely $75 \mu \mathrm{g} \mathrm{mL}^{-1}$ ), as obtained by the extraction of sorghum biocolorant in a solution of kanwu, did still not affect the growth of $L$. monocytogenes in suspension (Figure 3).

Dyeing wagashi using an alkaline extract would, next to the colouring effect, also increase the $\mathrm{pH}$. Therefore, aqueous extracts were used to test the antimicrobial activity and potential 
physico-chemical changes. The growth of $P$. chrysogenum and C. macrocarpum was not inhibited on wagashi dyed with sorghum biocolorant (Tables 1 and Figure 4). The sorghum biocolorant extract used for the test contained apigeninidin, 4-hydroxybenzoic acid and $p$ coumaric acid at $26.8,3.3$ and $2.3 \mu \mathrm{g} \mathrm{mL}^{-1}$, respectively.

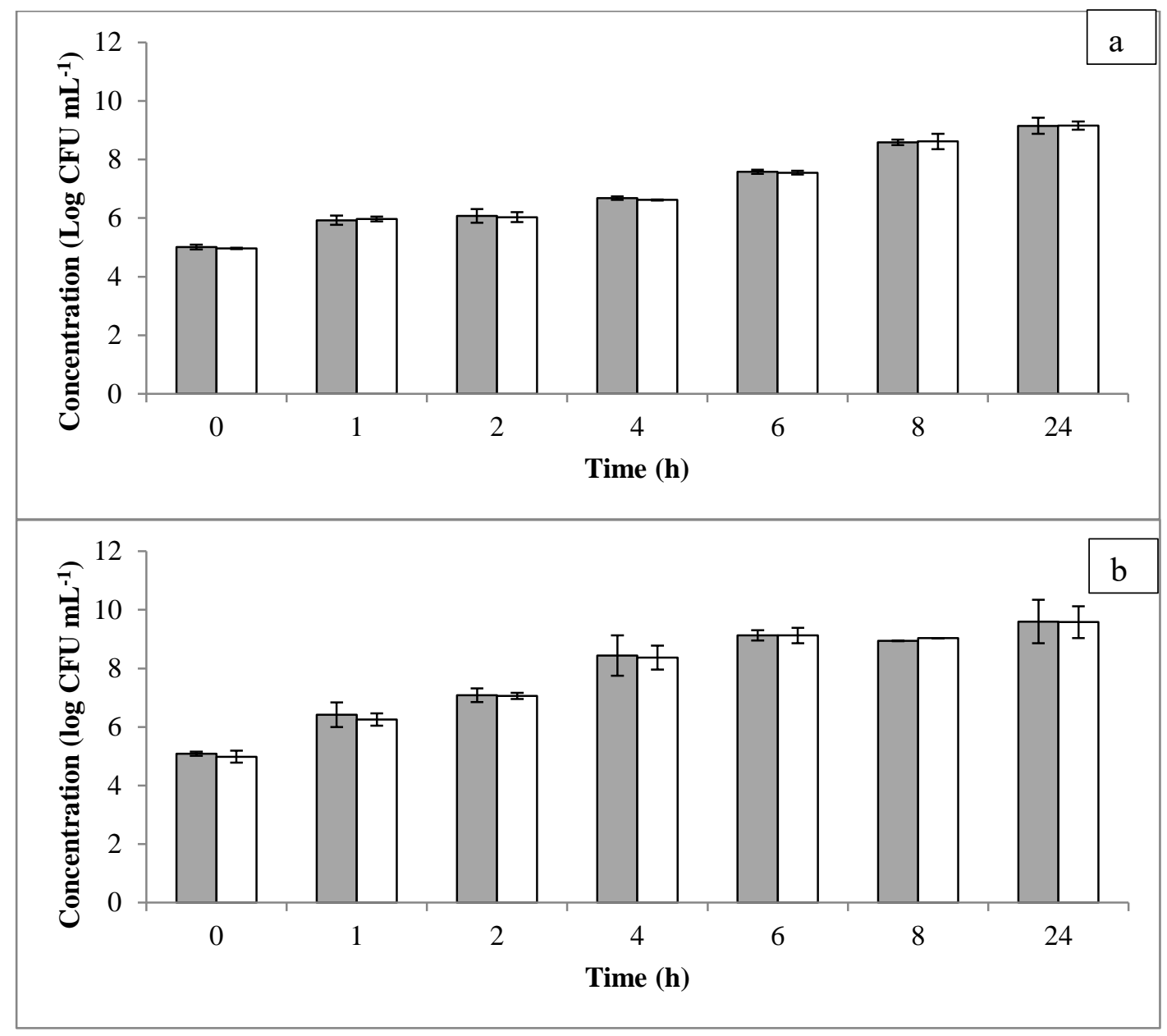

Figure 2. Growth of Listeria monocytogenes (a) and Escherichia coli $\mathrm{O} 157: \mathrm{H} 7$ (b) in dyed $(\square)$ and non-dyed ( $\square$ ) broth. Error bars represent standard deviations.

In table 1, two levels of contamination were tested for P. chrysogenum (i.e. 1.6 and $3.6 \mathrm{log}$ spores) and for C. macrocarpum (i.e. 1.9 and $2.9 \log$ spores). Apparently, fungi like $P$. chrysogenum and C. macrocarpum spread easily on dyed wagashi, even at a low spore contamination (Table 1). There was also no significant difference in the E. coli O157:H7 count on the dyed and the non-dyed wagashi samples (Table 2). This absence of an inhibitory effect indicates that the application of sorghum biocolorant, as done by traders in Benin, does not preserve wagashi from the proliferation of the fungi and pathogenic bacteria tested. 


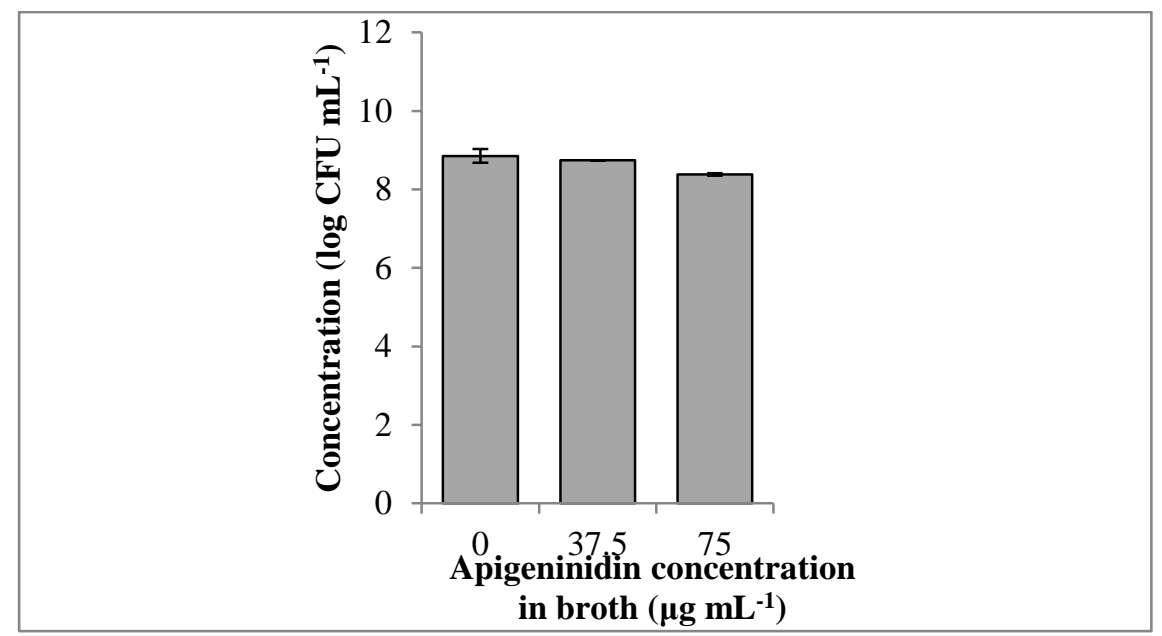

Figure 3. Growth of Listeria monocytogenes in broth with increasing apigeninidin concentration after incubation for $24 \mathrm{~h}$ at $37{ }^{\circ} \mathrm{C}$ (starting concentration $6.5 \log \mathrm{CFU} \mathrm{mL} \mathrm{m}^{-1}$ ). Error bars represent standard deviations.

Table 1. Growth of fungi on wagashi

\begin{tabular}{|c|c|c|c|c|c|}
\hline & \multirow{2}{*}{$\begin{array}{l}\text { Spores spot- } \\
\text { inoculated in } \\
\text { the centre of } \\
\text { wagashi } \\
\text { (log spores) }\end{array}$} & \multicolumn{4}{|c|}{$\begin{array}{l}\text { Growth of fungi on wagashi }\left(\mathrm{mm}^{2}\right) \text { after storage at } 28^{\circ} \mathrm{C} \\
\text { for } 72 \mathrm{~h}\end{array}$} \\
\hline & & $\begin{array}{l}\text { Positive } \\
\text { control } \\
(n=6)\end{array}$ & $\begin{array}{l}\text { Negative } \\
\text { control } \\
(n=6)\end{array}$ & $\begin{array}{l}\text { Cool-dyed } \\
\text { samples } \\
(n=6)\end{array}$ & $\begin{array}{l}\text { Hot-dyed } \\
\text { samples } \\
(n=6)\end{array}$ \\
\hline Penicillium & $1.6 \pm 0.0$ & $1.0 \pm 0.1 \mathrm{a}$ & $1.0 \pm 0.4 \mathrm{a}$ & $2.0 \pm 1.0 \mathrm{a}$ & $1.8 \pm 0.7 \mathrm{a}$ \\
\hline chrysogenum & $3.6 \pm 0.0$ & $1.3 \pm 0.4 \mathrm{a}$ & $1.0 \pm 0.3 \mathrm{a}$ & $2.2 \pm 0.1 \mathrm{~b}$ & $2.5 \pm 0.5 \mathrm{~b}$ \\
\hline Cladosporium & $1.9 \pm 0.0$ & $0.80 \pm 0.1 \mathrm{a}$ & $0.7 \pm 0.2 \mathrm{a}$ & $0.6 \pm 0.2 \mathrm{a}$ & $0.6 \pm 0.1 \mathrm{a}$ \\
\hline macrocarpum & $2.9 \pm 0.0$ & $1.1 \pm 0.6 \mathrm{a}$ & $1.1 \pm 0.9 \mathrm{a}$ & $1.2 \pm 0.3 \mathrm{a}$ & $1.6 \pm 0.6 \mathrm{a}$ \\
\hline
\end{tabular}

Mean \pm Standard deviation; values with the same letter in the same row are not significantly different at $5 \%$.

Although the application of natural biocolorant could have caused changes in the product properties of the soft cheese (Han et al., 2011), the dyeing of wagashi with the aqueous extract did not affect the physico-chemical characteristics, namely the $\mathrm{pH}$, dry matter, acid value, during the 3 days of storage (Table 3 ). 


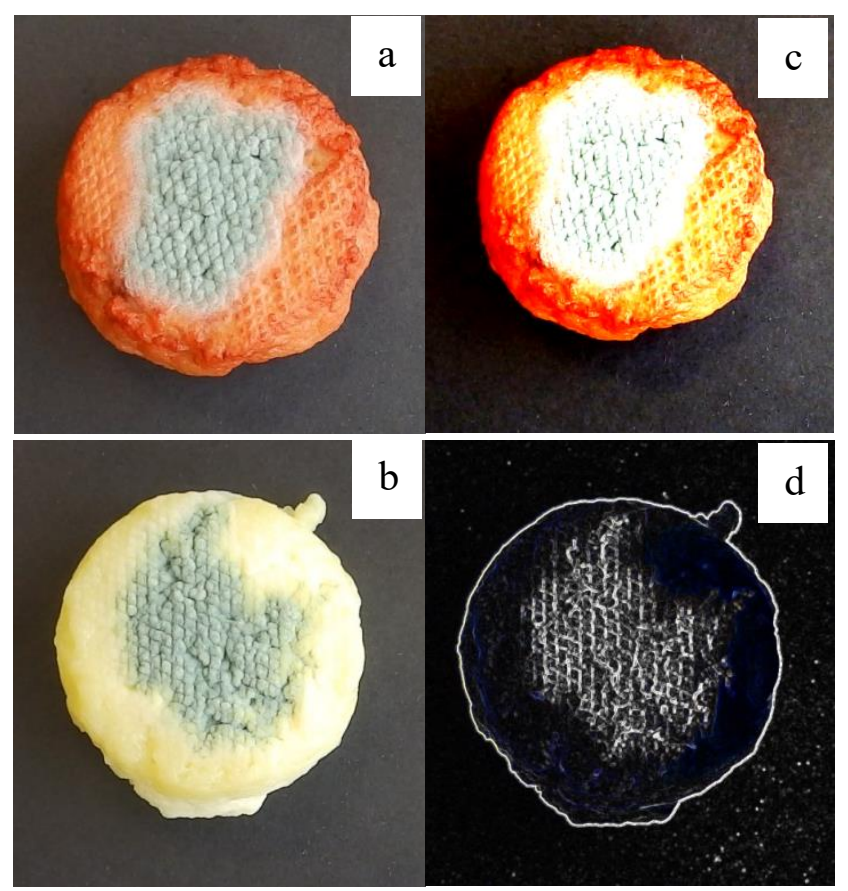

Figure 4. Analysis of the spreading area of fungi after growth on dyed (a) and control (b) wagashi with ImageJ 1.46r (c and d).

Table 2. Growth of Escherichia coli O157:H7 on wagashi

\begin{tabular}{|c|c|c|}
\hline \multirow{2}{*}{$\begin{array}{l}\text { Storage time } \\
\text { (h) }\end{array}$} & \multicolumn{2}{|c|}{ Escherichia coli $0157:$ H7 count $\left(\log\right.$ CFU g $\left.{ }^{-1}\right)$} \\
\hline & Control $(n=6)$ & Dyed wagashi $(\mathrm{n}=6)$ \\
\hline 0 & $5.0 \pm 0.2 \mathrm{a}$ & $5.0 \pm 0.2 \mathrm{a}$ \\
\hline 5 & $6.1 \pm 0.2 \mathrm{a}$ & $5.7 \pm 0.5 \mathrm{a}$ \\
\hline 24 & $7.9 \pm 0.2 \mathrm{a}$ & $7.8 \pm 0.3 \mathrm{a}$ \\
\hline
\end{tabular}

Mean \pm Standard deviation; values with the same letter in the same row are not significantly different at $5 \%$. 
Table 3. Physicochemical characteristics of dyed wagashi over time

\section{Storage time (h) Control $(\mathrm{n}=4) \quad$ Dyed wagashi $(\mathrm{n}=4)$}

\begin{tabular}{llll}
\hline $\mathrm{pH}$ & 0 & $6.7 \pm 0.1 \mathrm{a}$ & $6.7 \pm 0.1 \mathrm{a}$ \\
& 72 & $6.4 \pm 0.9 \mathrm{a}$ & $6.5 \pm 0.4 \mathrm{a}$ \\
\hline Acid value & 0 & $4.9 \pm 2.7 \mathrm{a}$ & $4.2 \pm 2.1 \mathrm{a}$ \\
$\left(\mathrm{mg} \mathrm{KOH} \mathrm{g}^{-1} \mathrm{DM}\right)$ & 72 & $12.0 \pm 3.5 \mathrm{~b}$ & $13.9 \pm 4.3 \mathrm{~b}$ \\
\hline Dry matter $(\%)$ & 0 & $31.1 \pm 3.0 \mathrm{a}$ & $32.8 \pm 2.7 \mathrm{a}$ \\
& 72 & $48.4 \pm 3.0 \mathrm{~b}$ & $52.3 \pm 9.2 \mathrm{~b}$
\end{tabular}

Mean \pm Standard deviation; values with the same letter in the same row and sub-column are not significantly different at $5 \%$.

\section{Survey on the application of sorghum biocolorant on wagashi}

Traders usually buy non-dyed wagashi on a production site and transport it to the towns for sale after additional processing. The treatments traders apply to wagashi before selling the cheese are a heat treatment ( $97.8 \%$ of the traders) and dyeing (100\% of the traders). As traders might have to keep wagashi several days at ambient temperature before sale, dyeing consists of a daily bath of wagashi in sorghum biocolorant and this practice is perceived as a way to prolong the product's shelf-life. White wagashi is preferably sold before the fourth day or otherwise kept until the next market day, corresponding to a shelf life of 8-10 days (Figure 5). On the contrary, dyed wagashi may intentionally be kept for more than 8-10 days to speculate and maximize its revenues (Figure 5). Indeed, a mean revenue increase of $11.5 \%$ was recorded when wagashi was dyed. 


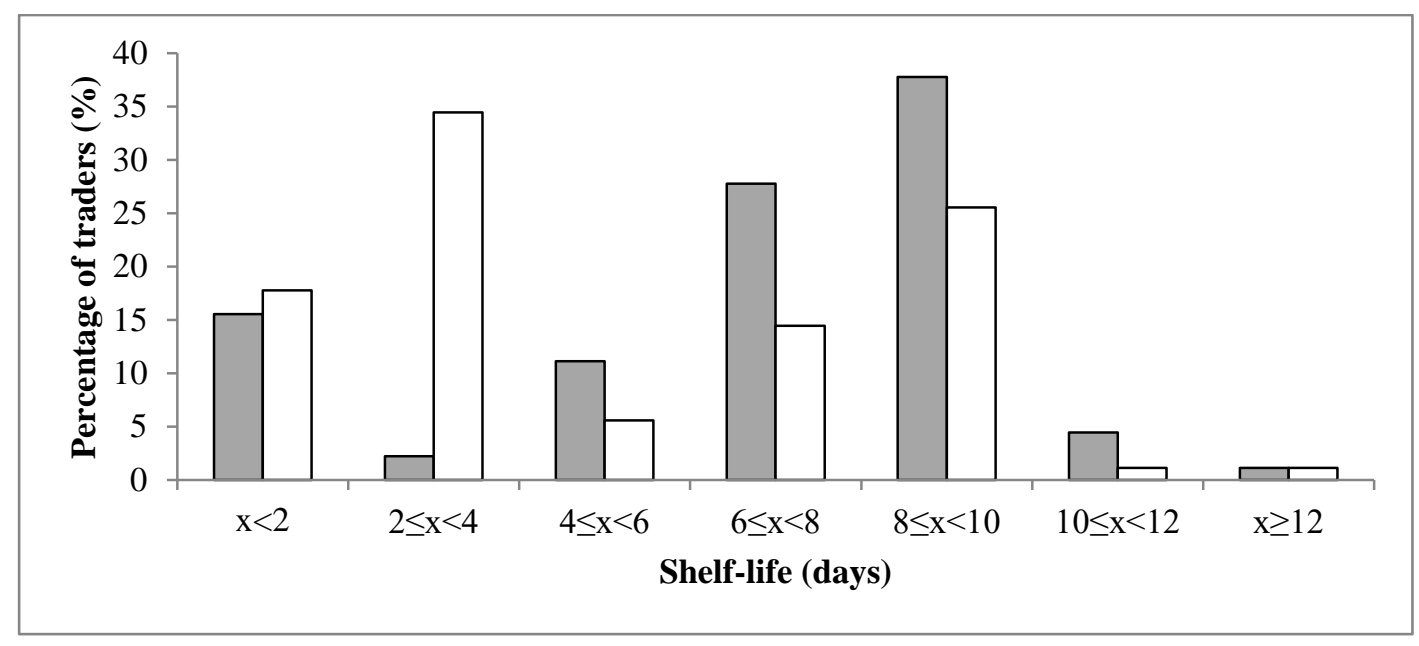

Figure 5. Percentage of traders willing to sell their wagashi when it is dyed ( $\square$ ) and non-dyed $(\square)$.

Two methods are used to extract sorghum biocolorant, i.e. alkaline and hot aqueous extraction. Alkaline extraction is reported by $87.7 \%$ of the traders, although its use varies among traders. Indeed, wagashi could be cooked in the alkaline extract ( $24.4 \%$ of the traders) or let to soak in the cool alkaline extract (43.3\% of the traders). Some traders $(20 \%)$ suggest that the addition of warm water to the cool alkaline extract speeds up the dyeing process. The use of the hot aqueous extract $(12.3 \%$ of the traders) is always associated to cooking of the extract with wagashi.

The dyeing of the wagashi by soaking it in an extract of sorghum biocolorant may last for up to two hours, although $52 \%$ of the traders apply a maximum soaking time of $30 \mathrm{~min}$. The reasons to apply dye sorghum on wagashi are defined by traders as a way to enhance the sensorial quality (all traders), to keep the products looking fresh (mentioned by $49 \%$ of the traders), and to contribute to product preservation because its delays spoiling and increases the acidity ( $31 \%$ of the traders).

\section{DISCUSSION}

Bright colours are key factors in the perception of the sensorial quality of food products and therefore impact consumer choice and preference (Koch \& Koch, 2003; Resurreccion, 2004) Traders in Benin use the natural red sorghum colorant to make wagashi attractive for consumers. Adding a colouring agent to a food may affect consumers' food preferences (Clydesdale, 1993). Hence, the colouring of wagashi could be considered as a value-adding unit operation by traders. The alkaline and hot aqueous extracts are commonly used extracts 
from dye sorghum to impact food colour in Benin (Akogou et al., 2018a). These extracts differ in apigeninidin content, colour density and $\mathrm{pH}$. The apigeninidin content and the colour density of the alkaline extract can be three times higher than that of the aqueous extract. In addition, the $\mathrm{pH}$ of the alkaline extract is around 8-9 whereas it is 7 for the hot aqueous extract (Akogou et al., 2018a). An extract of $50 \mu \mathrm{M}$ apigeninidin, equivalent to $13 \mu \mathrm{g} \mathrm{mL}^{-1}$, was reported to inhibit the growth of fungi and bacteria (particularly Gram positive) (Schutt \& Netzly, 1991; Stonecipher et al., 1993). However, the results of the challenge tests on wagashi and in broth with apigeninidin at levels of $23.5 \mu \mathrm{g} \mathrm{mL}^{-1}$ and $75 \mu \mathrm{g} \mathrm{mL}^{-1}$, respectively, did not corroborate those findings. Although the antiproliferative activity of phenolic phytoalexins has been largely proven and is even proposed as a natural preservative to fungal pathogens (Kil et al., 2009; Klančnik et al., 2009; Hasegawa et al., 2014; Sanzani et al., 2014), detoxification of phytoalexins by microorganisms could change their effectiveness as natural preservatives (Jeandet, 2015). Naturally occurring weak acids, e.g. benzoic acid and $p$ coumaric, are widely used as food preservatives (Brul \& Coote, 1999; Stojković et al., 2013), and it has been reported that concentrations of 7 and $1.87 \mathrm{mg} \mathrm{mL}^{-1}$ of benzoic acid and $p$ coumaric, respectively, are required for an effective inhibition of pathogen growth in food matrices (Cruz-Romero et al., 2013; Stojković et al., 2013). Conversely, the benzoic acid and $p$-coumaric acid contents in sorghum biocolorant apparently are not sufficient for preservative purposes. With total counts of 4.6 and $6.7 \log \mathrm{CFU} \mathrm{g} \mathrm{g}^{-1}$ for E. coli, and moulds and yeasts, respectively, reported in samples of wagashi (Aïssi et al., 2009), use of sorghum biocolorant could not be acclaimed to function as a natural preservative in wagashi. As processors also use alkaline colorant extracts, it is recommended to also test the antimicrobial effects of these extracts in wagashi, though non-antibacterial activity was observed in the current study for the tested pathogens in broth. Although only $31 \%$ of traders clearly mention the use of sorghum extract as a food preservative in wagashi, this mistaken notion could present a risk for consumers when no heat treatment is applied to the cheese within 3 days of storage. Moreover, since microbial growth is better visible on wagashi that has not received a colouring treatment, it is possible that the red colorant masks microbial contamination, thus causing a food safety risk. Since the colorant is not sterilised, possible fungal and bacterial contaminants could be introduced via the leaf sheaths (Gadgil, 1998; Johnson et al., 2014; Dekker et al., 2015). Washing of the sorghum leaf sheaths in potable water could be a first step to reduce microbial contaminants via the leaf sheaths (Ameyapoh et al., 2008). Next, a hot extraction method at $86^{\circ} \mathrm{C}$ during 15 min could be recommended to inactivate most of the pathogenic cells (Nazarowec-White \& Farber, 1997; Ameyapoh et al., 2008). 
The use of sorghum biocolorant could be of interest to the food industry, in particular the dairy and meat industries, looking for a stable natural colorant with a high colour density and potential health-supporting attributes (e.g. antioxidant properties) (Kayodé et al., 2011; Hidalgo et al., 2012; Boto-Ordóñez et al., 2014; Kumar et al., 2015a; Kumar et al., 2015b; Gallego \& Salminen, 2016; Akogou et al., 2018a; Akogou et al., 2018b). However, this potential impact has to be investigated further.

\section{CONCLUSION}

The anti-fungal and anti-bacterial properties of dye sorghum extracts could not be confirmed in nutrient-rich broth and on wagashi, a traditional West African soft cheese, as a model for a popular food application. Hence, it is likely that the most important attribute of the brightly red biocolorant from dye sorghum in Benin is its eye-catching property. This might open avenues for application as natural colorant in a variety of (dairy and meat-based) industrially produced foods, in particular when colour stability and potential health-supporting properties can be supported in further research.

\section{SUPPORTING INFORMATION}

Figure S1. Non-dyed (A) and dyed (B) wagashi (with $44 \mathrm{~mm}$ diameter) used for the challenge tests.

Appendix S1. Questionnaire des transformatrices de fromage local (wagashi). The original survey questionnaire in French as used in the study.

Appendix S2. Questionnaire for processors of local soft cheese (wagashi). The survey questionnaire translated in English.

\section{ACKNOWLEDGEMENTS}

This research is funded by Netherlands Fellowship Programmes (Grant award CF8188/2012). The authors thank Wisse de Beer, Judith Wolkers-Rooijackers and Ida Jongenburger for assistance during the experiments. 


\section{REFERENCES}

Adetunji, V. O. (2008). Comparative assessment of the effect of crude extracts of Carica papaya and Terminalia cattapa, and a bacteriocin on vacuum-packed West African soft cheese (wara). African Journal of Microbiologie Research, 2 (10), 272-276.

Adetunji, V. O., \& Arigbede, M. I. (2011). Occurrence of E. coli O157: H7 and Listeria monocytogenes and identification of Hazard Analysis Critical Control Points (HACCPs) in production operations of a typical tropic cheese wara and yoghurt. Pakistan Journal of Nutrition.

Adeyeye, S. A. O., \& Adeyeye, S. A. O. (2017). A preliminary study on the quality and safety of street-vended warankasi (a Nigerian soft white cheese) from Ibadan, Oyo state, Nigeria. British Food Journal, 119 (2), 322-330.

Aïssi, V. M., Soumanou, M. M., Bankolè, H., Toukourou, F., \& de Souza, C. A. (2009). Evaluation of hygienic and mycological quality of local cheese marketed in Benin. Australian Journal of Basic and Applied Sciences, 3 (3), 2397-2404.

Akogou, F. U. G., Kayodé, A. P. P., den Besten, H. M. W., \& Linnemann, A. R. (2018a). Extraction methods and food uses of a natural red colorant from dye sorghum. Journal of the Science of Food and Agriculture, 98 (1), 361-368.

Akogou, F. U. G., Kayodé, A. P. P., den Besten, H. M. W., Linnemann, A. R., \& Fogliano, V. (2018b). Effects of processing and storage on the stability of the red biocolorant apigeninidin from sorghum. LWT-Food Science and Technology, 90, 592-597.

Alalade, O., \& Adeneye, J. (2006). The effect of storage period on the chemical composition and coliform microflora of wara cheese. International Journal of Dairy Science, 1 (2), 126130.

Ameyapoh, Y., de Souza, C., \& Traore, A. S. (2008). Hygienic quality of traditional processing and stability of tomato (Lycopersicon esculentum) puree in Togo. Bioresource Technology, 99 (13), 5798-5803.

Assogbadjo, A. E., Sinsin, B., Codjia, J. T. C., \& Van Damme, P. (2005). Ecological diversity and pulp, seed and kernel production of the baobab (Adansonia digitata) in Benin. Belgian Journal of Botany, 138 (1), 47-56.

Aworh, O. C., \& Egounlety, M. (1985). Preservation of West African soft cheese by chemical treatment. Journal of Dairy Research, 52 (1), 189-195.

Boto-Ordóñez, M., Urpi-Sarda, M., Queipo-Ortuño, M. I., Tulipani, S., Tinahones, F. J., \& Andres-Lacueva, C. (2014). High levels of Bifidobacteria are associated with increased levels 
of anthocyanin microbial metabolites: a randomized clinical trial. Food \& Function, 5 (8), 1932-1938.

Brul, S., \& Coote, P. (1999). Preservative agents in foods: mode of action and microbial resistance mechanisms. International Journal of Food Microbiology, 50 (1), 1-17.

Bup, D. N., Abi, C. F., Tenin, D., Kapseu, C., \& Tchiegang, C. (2012). Optimisation of the cooking process of sheanut kernels (Vitellaria paradoxa Gaertn.) using the Doehlert experimental design. Food and Bioprocess Technology, 5 (1), 108-117.

Butkhup, L., Chowtivannakul, S., Gaensakoo, R., Prathepha, P., \& Samappito, S. (2016). Study of the phenolic composition of Shiraz red grape cultivar (Vitis vinifera L.) cultivated in north-eastern Thailand and its antioxidant and antimicrobial activity. South African Journal of Enology and Viticulture, 31 (2), 89-98.

Cadmus, S., Ajunwa, O., Adeleke, A., Agada, C., \& Awoyele, A. (2013). Mini-review: theoretical and onsite evaluation of hazard potentials in the local production of wara; an indigenous West African soft cheese. British Microbiology Research Journal, 3 (3), 218-234. Clydesdale, F. M. (1993). Color as a factor in food choice. Critical Reviews in Food Science and Nutrition, 33 (1), 83-101.

Cruz-Romero, M., Murphy, T., Morris, M., Cummins, E., \& Kerry, J. (2013). Antimicrobial activity of chitosan, organic acids and nano-sized solubilisates for potential use in smart antimicrobially-active packaging for potential food applications. Food Control, 34 (2), 393397.

Dekker, D. M., Krumkamp, R., Sarpong, N., Frickmann, H., Boahen, K. G., Frimpong, M., Asare, R., Larbi, R., Hagen, R. M., \& Poppert, S. (2015). Drinking water from dug wells in rural Ghana - Salmonella contamination, environmental factors, and genotypes. International Journal of Environmental Research and Public Health, 12 (4), 3535-3546.

Dubey, V. K., \& Jagannadham, M. (2003). Procerain, a stable cysteine protease from the latex of Calotropis procera. Phytochemistry, 62 (7), 1057-1071.

FDA, 2016. Food additive list. http://www.fda.gov/Food/IngredientsPackagingLabeling/FoodAdditivesIngredients/ucm0910 48.htm\#ftnB.

Gadgil, A. (1998). Drinking water in developing countries. Annual Review of Energy and the Environment, 23 (1), 253-286.

Gallego, C. G., \& Salminen, S. (2016). Novel probiotics and prebiotics: how can they help in human gut microbiota dysbiosis? Applied Food Biotechnology, 3 (2), 72-81.

Han, J., Britten, M., St-Gelais, D., Champagne, C. P., Fustier, P., Salmieri, S., \& Lacroix, M. 
(2011). Effect of polyphenolic ingredients on physical characteristics of cheese. Food Research International, 44 (1), 494-497.

Hasegawa, M., Mitsuhara, I., Seo, S., Okada, K., Yamane, H., Iwai, T., \& Ohashi, Y. (2014). Analysis on blast fungus-responsive characters of a flavonoid phytoalexin sakuranetin; accumulation in infected rice leaves, antifungal activity and detoxification by fungus. Molecules, 19 (8), 11404-11418.

Hidalgo, M., Oruna-Concha, M. J., Kolida, S., Walton, G. E., Kallithraka, S., Spencer, J. P., \& de Pascual-Teresa, S. (2012). Metabolism of anthocyanins by human gut microflora and their influence on gut bacterial growth. Journal of Agricultural and Food Chemistry, 60 (15), 3882-3890.

Jeandet, P. (2015). Phytoalexins: current progress and future prospects. Molecules, 20 (2), 2770-2774.

Johnson, R. C., Segla, H., Dougnon, T. V., Boni, G., Bankole, H. S., Houssou, C., \& Boko, M. (2014). Situation of water, hygiene and sanitation in a peri-urban area in Benin, West Africa: the case of Sèmè-Podji. Journal of Environmental Protection, 5 (12), 1277-1283.

Kayodé, A. P., Nout, M. R., Linnemann, A. R., Hounhouigan, J. D., Berghofer, E., \& Siebenhandl-Ehn, S. (2011). Uncommonly high levels of 3-deoxyanthocyanidins and antioxidant capacity in the leaf sheaths of dye sorghum. Journal of Agricultural and Food Chemistry, 59 (4), 1178-1184.

Kil, H. Y., Seong, E. S., Ghimire, B. K., Chung, I.-M., Kwon, S. S., Goh, E. J., Heo, K., Kim, M. J., Lim, J. D., \& Lee, D. (2009). Antioxidant and antimicrobial activities of crude sorghum extract. Food Chemistry, 115 (4), 1234-1239.

Klančnik, A., Guzej, B., Hadolin Kolar, M., Abramovič, H., \& Smole Možina, S. (2009). In vitro antimicrobial and antioxidant activity of commercial rosemary extract formulations. Journal of Food Protection, 72 (8), 1744-1752.

Koch, C., \& Koch, E. C. (2003). Preconceptions of taste based on color. Journal of Psychology, 137 (3), 233-242.

Kumar, H., Salminen, S., Verhagen, H., Rowland, I., Heimbach, J., Bañares, S., Young, T., Nomoto, K., \& Lalonde, M. (2015a). Novel probiotics and prebiotics: road to the market. Current Opinion in Biotechnology, 32, 99-103.

Kumar, Y., Yadav, D. N., Ahmad, T., \& Narsaiah, K. (2015b). Recent trends in the use of natural antioxidants for meat and meat products. Comprehensive Reviews in Food Science and Food Safety, 14 (6), 796-812.

Ling, M. P., Lien, K. W., Wu, C. H., Ni, S. P., Huang, H. Y., \& Hsieh, D. P. (2015). Dietary 
exposure estimates for the food preservatives benzoic acid and sorbic acid in the total diet in Taiwan. Journal of Agricultural and Food Chemistry, 63 (7), 2074-2082.

Martins, N., Roriz, C. L., Morales, P., Barros, L., \& Ferreira, I. C. (2016). Food colorants: challenges, opportunities and current desires of agro-industries to ensure consumer expectations and regulatory practices. Trends Food Sci Technol, 52, 1-15.

McCann, D., Barrett, A., Cooper, A., Crumpler, D., Dalen, L., Grimshaw, K., Kitchin, E., Lok, K., Porteous, L., \& Prince, E. (2007). Food additives and hyperactive behaviour in 3year-old and 8/9-year-old children in the community: a randomised, double-blinded, placebocontrolled trial. The Lancet, 370 (9598), 1560-1567.

Nazarowec-White, M., \& Farber, J. (1997). Thermal resistance of Enterobacter sakazakii in reconstituted dried-infant formula. Lett Appl Microbiol, 24 (1), 9-13.

Nostro, A., Germano, M., D’angelo, V., Marino, A., \& Cannatelli, M. (2000). Extraction methods and bioautography for evaluation of medicinal plant antimicrobial activity. Lett Appl Microbiol, 30 (5), 379-384.

Omemu, A., Taiwo, G., \& Obuotor, T. (2014). Microbiological assessment and prevalence of food borne pathogens in street vended Wara-Nigerian white cheese. Am J Food Nutr, 2 (4), $59-62$

Petti, C., Kushwaha, R., Tateno, M., Harman-Ware, A. E., Crocker, M., Awika, J., \& DeBolt, S. (2014). Mutagenesis breeding for increased 3-deoxyanthocyanidin accumulation in leaves of Sorghum bicolor (L.) Moench: a source of natural food pigment. Journal of Agricultural and Food Chemistry, 62 (6), 1227-1232.

Poloni, A., \& Schirawski, J. (2014). Red card for pathogens: phytoalexins in sorghum and maize. Molecules, 19 (7), 9114-9133.

Raheem, D., Suri, N., \& Saris, P. E. (2007). The characterization and application of Calotropis procera, a coagulant in Nigerian wara cheese. International Journal of Food Science and Technology, 42 (2), 220-223.

Ramos, M., Araújo, E., Jucá, T., Monteiro-Moreira, A., Vasconcelos, I., Moreira, R., Viana, C., Beltramini, L. M., Pereira, D., \& Moreno, F. (2013). New insights into the complex mixture of latex cysteine peptidases in Calotropis procera. International Journal of Biological Macromolecules, 58, 211-219.

Resurreccion, A. (2004). Sensory aspects of consumer choices for meat and meat products. Meat Science, 66 (1), 11-20.

Saliu, B. K., Agbabiaka, T. O., Sule, I. O., \& Gambari-Ambali, R. O. (2014). Assessment of local methods of processing for the preservation of the physico-chemical properties and 
microbiological quality of two local cheeses in Ilorin, Nigeria. Journal of Microbiology, Biotechnology and Food Sciences, 3 (4), 337.

Sanzani, S. M., Schena, L., \& Ippolito, A. (2014). Effectiveness of phenolic compounds against citrus green mould. Molecules, 19 (8), 12500-12508.

Schutt, C., \& Netzly, D. (1991). Effect of apiforol and apigeninidin on growth of selected fungi. Journal of Chemical Ecology, 17 (11), 2261-2266.

Shih, C.-H., Siu, S.-O., Ng, R., Wong, E., Chiu, L. C., Chu, I. K., \& Lo, C. (2007). Quantitative analysis of anticancer 3-deoxyanthocyanidins in infected sorghum seedlings. Journal of Agricultural and Food Chemistry, 55 (2), 254-259.

Singh, A. N., \& Dubey, V. K. (2011). Exploring applications of procerain B, a novel protease from Calotropis procera, and characterization by $\mathrm{N}$-terminal sequencing as well as peptide mass fingerprinting. Applied Biochemistry and Biotechnology, 164 (5), 573-580.

Sousa, A., Araújo, P., Azevedo, J., Cruz, L., Fernandes, I., Mateus, N., \& de Freitas, V. (2016). Antioxidant and antiproliferative properties of 3-deoxyanthocyanidins. Food Chemistry, 192, 142-148.

Stevens, L. J., Burgess, J. R., Stochelski, M. A., \& Kuczek, T. (2014). Amounts of artificial food colors in commonly consumed beverages and potential behavioral implications for consumption in children. Clinical Pediatrics, 53 (2), 133-140.

Stojković, D., Petrović, J., Soković, M., Glamočlija, J., Kukić-Marković, J., \& Petrović, S. (2013). In situ antioxidant and antimicrobial activities of naturally occurring caffeic acid, $p$ coumaric acid and rutin, using food systems. Journal of the Science of Food and Agriculture, 93 (13), 3205-3208.

Stonecipher, L. L., Hurley, P. S., \& Netzly, D. H. (1993). Effect of apigeninidin on the growth of selected bacteria. Journal of Chemical Ecology, 19 (5), 1021-1027.

Vegara, S., Martí, N., Mena, P., Saura, D., \& Valero, M. (2013). Effect of pasteurization process and storage on color and shelf-life of pomegranate juices. LWT-Food Science and Technology, 54 (2), 592-596.

Wrolstad, R. E., \& Culver, C. A. (2012). Alternatives to those artificial FD\&C food colorants. Annual Review of Food Science and Technology, 3, 59-77.

Yang, L., Browning, J. D., \& Awika, J. M. (2009). Sorghum 3-deoxyanthocyanins possess strong phase II enzyme inducer activity and cancer cell growth inhibition properties. Journal of Agricultural and Food Chemistry, 57 (5), 1797-1804. 


\section{SUPPORTING INFORMATION}
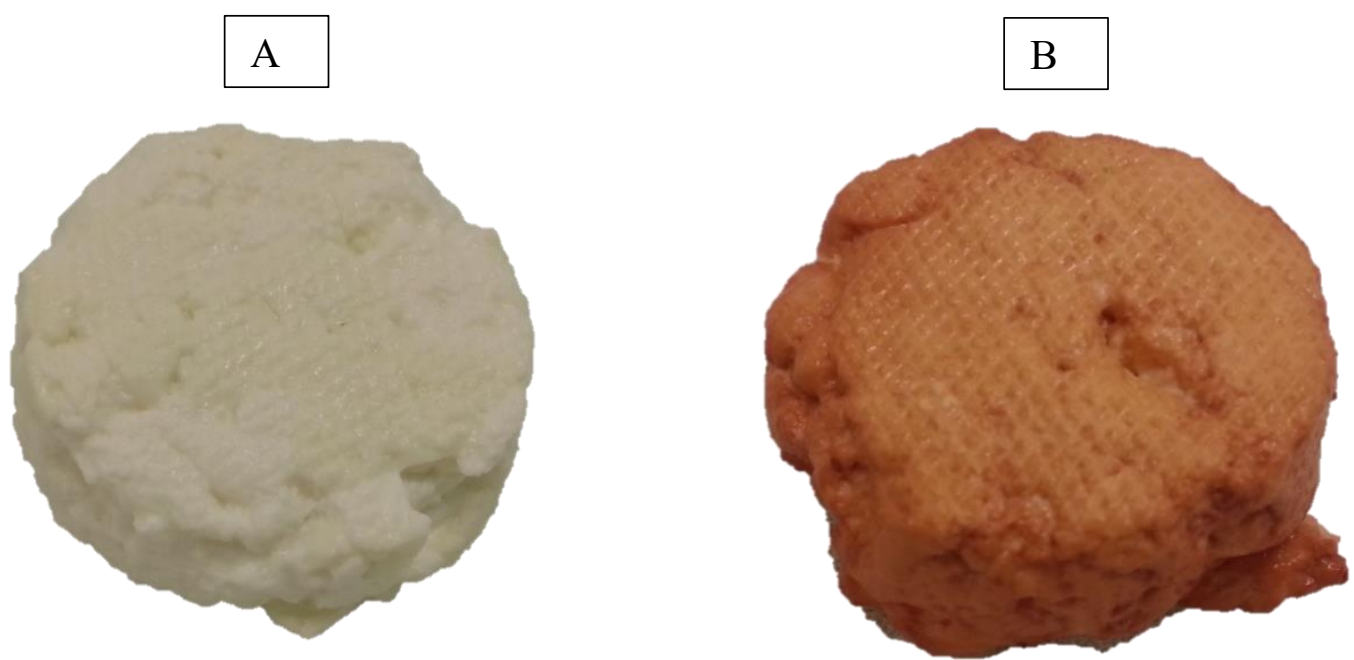

Figure S1. Non-dyed (A) and dyed (B) wagashi (with $44 \mathrm{~mm}$ diameter) used for the challenge tests 
Appendix S1. Questionnaire des transformatrices de fromage local (wagashi)

(Questionnaire individuel destiné aux transformatrices de fromage local utilisant la gaine de sorgho colorant)

Fiche $\mathrm{N}^{\circ}$ :

Date de l'enquête:

Nom de l'enquêteur:

Généralités

\begin{tabular}{|l|l|}
\hline Caractéristiques & Modalités (à pré-remplir avant l'enquête) \\
\hline Département & \\
\hline Commune & \\
\hline Arrondissement & \\
\hline Village & \\
\hline Hameau ou quartier & \\
\hline
\end{tabular}

\section{Identification de l'enquêté}

1-Nom:

2-Prénom:

3-Age:

4-Sexe : masculin $\square \quad$ féminin $\square$

5-Ethnie : bariba $\square \quad$;peuhl $\square \quad$;somba $\square \quad$;otamari $\square \quad$;natimba $\square \quad$;pila-pila $\square$ lokpa $\square \quad$;yandé $\square \quad$;berba $\square \quad$;lama $\square \quad$;mahi $\square \quad$;nago $\square$ autres (à préciser)

6-Religion : musulman $\square \quad$; chrétien $\square \quad$; religion traditionnelle $\square \quad$ sans religion $\square$ Autres religions (à préciser)

7-Niveau d'éducation : non lettré $\square$ lettré niveau primaire $\square$

lettré niveau secondaire lettré niveau universitaire

9-Profession/occupation : 
1- Comment colorez-vous le wagashi?

\begin{tabular}{|c|c|c|c|c|c|}
\hline \multirow[t]{2}{*}{ Opérations unitaires } & \multicolumn{2}{|c|}{ Réponse } & \multirow[t]{2}{*}{ Ingrédients } & \multicolumn{2}{|c|}{ Réponse } \\
\hline & Oui & Non & & Oui & Non \\
\hline \multirow[t]{3}{*}{ Cuisson du wagashi } & & & Kanmou ou kanwanboguo & & \\
\hline & & & Bicarbonate & & \\
\hline & & & Sel & & \\
\hline \multicolumn{3}{|l|}{ Extraction du colorant } & Kanmou & & \\
\hline \multirow{2}{*}{ à froid $\square$} & \multirow{2}{*}{\multicolumn{2}{|c|}{ à chaud $\square$}} & Cendres & & \\
\hline & & & Bicarbonate & & \\
\hline
\end{tabular}

\begin{tabular}{|c|c|c|c|}
\hline \multirow[t]{2}{*}{ Opérations unitaires } & \multirow[t]{2}{*}{ Durée de l'opération unitaire } & \multicolumn{2}{|c|}{ Réponse } \\
\hline & & Oui & Non \\
\hline \multirow[t]{2}{*}{ Coloration du wagashi: } & Moins de 15 minutes & & \\
\hline & 15 minutes à 30 minutes & & \\
\hline \multirow{3}{*}{$\begin{array}{l}\text { dans de l'eau à température ambiante } \\
\text { dans de l'eau tiède }\end{array}$} & 30 minutes à 45 minutes & & \\
\hline & 45 minutes à 1 heure & & \\
\hline & 1 heure à 1 heure 30 minutes & & \\
\hline \multirow[t]{2}{*}{ au cours du chauffage du wagashi } & 1 heure 30 minutes à 2 heures & & \\
\hline & Autres durée (à préciser) & & \\
\hline
\end{tabular}

2- Est-ce qu'un colorant de couleur plus intense permet de réduire la durée de la coloration de wagashi?
Oui
Non

3- Quelles sont les raisons de la coloration du wagashi?

\begin{tabular}{|l|l|l|}
\hline Raisons & Oui & Non \\
\hline Rendre le wagashi attrayant & & \\
\hline Masquer les tâches du wagashi et uniformiser la couleur & & \\
\hline Retarde la pourriture du wagashi & & \\
\hline Retarde la fermentation du produit & & \\
\hline Autres : (à préciser) & & \\
\hline
\end{tabular}


4- Quelle est la durée de conservation des wagashi suivant?

\begin{tabular}{|l|lll|}
\hline & Indication de la durée de conservation \\
\hline $\begin{array}{l}\text { Wagashi blanc acheté directement } \\
\text { chez les peulhs }\end{array}$ & Faible $\square \quad$ moyenne $\square$ & longue $\square$ \\
\hline Wagashi cuit avec sel et kanmou & Faible $\square$ & moyenne $\square$ & longue $\square$ \\
\hline $\begin{array}{l}\text { Wagashi cuit avec sel et kanmou et } \\
\text { coloré en rouge avec les gaines de } \\
\text { sorgho colorant }\end{array}$ & Faible $\square$ & moyenne $\square$ & longue $\square$ \\
\hline
\end{tabular}

5- $\quad$ En période de mévente quelle est la durée de conservation maximale que vous avez déjà enregistrée pour le wagashi rouge?

\begin{tabular}{|c|c|c|c|c|}
\hline & Durée de co & servation ma & iale & \\
\hline Wagashi rouge & $\begin{array}{l}1 \text { jour } \square \\
4 \text { jours } \square \\
7 \text { jours } \square \\
10 \text { jours } \square \\
\text { Plus de } 12 \text { j }\end{array}$ & $\begin{array}{l}2 \text { jours } \square \\
5 \text { jours } \square \\
8 \text { jours } \square \\
11 \text { jours } \square \\
\text { Irs } \square\end{array}$ & $\begin{array}{l}3 \text { jours } \\
6 \text { jours } \\
9 \text { jours } \\
12 \text { jours }\end{array}$ & $\begin{array}{l}\square \\
\square \\
\square \\
\square\end{array}$ \\
\hline
\end{tabular}

6- Et si c'était du wagashi blanc pourrait on atteindre une telle durée de conservation?

\begin{tabular}{|c|c|c|c|c|}
\hline & \multicolumn{4}{|c|}{ Durée de conservation maximale } \\
\hline Wagashi blanc & $\begin{array}{l}1 \text { jour } \square \\
4 \text { jours } \square \\
7 \text { jours } \square \\
10 \text { jours } \square \\
\text { Plus de } 12 \text { j }\end{array}$ & $\begin{array}{l}2 \text { jours } \square \\
5 \text { jours } \square \\
8 \text { jours } \square \\
11 \text { jours } \square \\
\text { Irs } \square\end{array}$ & $\begin{array}{l}3 \text { jours } \\
6 \text { jours } \\
9 \text { jours } \\
12 \text { jours }\end{array}$ & $\begin{array}{l}\square \\
\square \\
\square \\
\square\end{array}$ \\
\hline
\end{tabular}


7- $\quad$ En cas de mévente, préciser la fréquence de recuisson et de recoloration du wagashi.

\begin{tabular}{|l|lllll|}
\hline & $\begin{array}{l}\text { Fréquence de nouvelles cuissons et de } \\
\text { recolorations }\end{array}$ & & & & \\
\hline Nouvelle cuisson avec du sel et kanmou & 1 jour $\square$ & 2 jours & $\square$ & 3 jours & $\square$ \\
& 4 jours $\square$ & 5 jours & $\square$ & 6 jours & $\square$ \\
\hline Recoloration & $\begin{array}{llllll}\text { jour } \\
\end{array}$ & 2 jours & $\square$ & 3 jours & $\square$ \\
& 4 jours $\square$ & 5 jours & $\square$ & 6 jours & $\square$ \\
\hline
\end{tabular}

8- Quelle taille de wagashi vendez-vous?

Petite taille $\square \quad$ Taille moyenne $\square \quad$ Grande taille

9- $\quad$ Pourquoi avez-vous choisi les wagashi de cette taille?

10- Est-ce que la quantité de gaines utilisée est différente selon la taille du wagashi?
Oui
Non

Si oui expliquez votre réponse :

11- Est-ce que la durée de séjour dans l'eau de coloration est différente selon la taille du wagashi?
Oui
Non

Si oui expliquez votre réponse : 
12- Veuillez préciser les coûts des matières utilisées

\begin{tabular}{|c|c|c|c|c|}
\hline Etapes & Matières premières & Quantité & Prix & Coût \\
\hline \multirow{8}{*}{$\begin{array}{l}\text { Cuisson } \quad \mathrm{du} \\
\text { wagashi }\end{array}$} & Wagashi & & & \\
\hline & Eau & & & \\
\hline & Kanmou & & & \\
\hline & Sel & & & \\
\hline & Sachets & & & \\
\hline & Bois/Charbon & & & \\
\hline & Autres & & & \\
\hline & Total 1 & & & \\
\hline \multirow[t]{5}{*}{$\begin{array}{l}\text { Coloration } \mathrm{du} \\
\text { wagashi }\end{array}$} & $\begin{array}{l}\text { Gaines de sorgho } \\
\text { (Nombre de botte) }\end{array}$ & & & \\
\hline & Eau & & & \\
\hline & Kanmou /Cendres & & & \\
\hline & Autres & & & \\
\hline & Total 2 & & & \\
\hline
\end{tabular}

13- Quel est le prix de votre wagashi rouge?

14- Quel est le prix de votre wagashi blanc sans la coloration?

15- Quel est le temps alloué à chaque tâche ?

\begin{tabular}{|l|l|}
\hline Tâche & Temps alloué (minutes) \\
\hline Cuisson du wagashi & \\
\hline Coloration du wagashi & \\
\hline Total & \\
\hline
\end{tabular}


Appendix S2. Questionnaire for processors of local soft cheese (wagashi)

Sheet $\mathrm{N}^{\circ}$ :

Date of the interview:

Name of the investigator:

\section{General information}

\begin{tabular}{|l|l|}
\hline Characteristics & Modalities (fill before the interview) \\
\hline Department & \\
\hline Town & \\
\hline Borough & \\
\hline Village & \\
\hline Hamlet or neighbourhood & \\
\hline
\end{tabular}

\section{Identification of the respondent}

1-Name

2-First name :

3-Age :

4-Sex : male

female

5-Ethnic group : bariba $\square \quad$;peuhl $\square \quad$;somba $\square \quad$;otamari $\square \quad$;natimba $\square \quad$;pilapila $\square$;lokpa $\square \quad$;yandé $\square \quad$;berba $\square \quad$;lama $\square \quad$;mahi $\square \quad$;nago Others (specify).

6-Religion : Muslim $\square \quad$; Christian $\square \quad$; Endogenous religion $\square$ Atheist $\square$

Other religions (specify) $\square$.

7- Education : No academic education $\square$ Primary school $\square$

Secondary School University school

9-Profession : 
1- How the wagashi dyeing is done?

\begin{tabular}{|c|c|c|c|c|c|}
\hline \multirow[t]{2}{*}{ Unit operations } & \multicolumn{2}{|c|}{ Response } & \multirow[t]{2}{*}{ Ingredient } & \multicolumn{2}{|c|}{ Response } \\
\hline & Yes & No & & Yes & No \\
\hline \multirow[t]{3}{*}{ Wagashi cooking } & & & Kanwu & & \\
\hline & & & Bicarbonate & & \\
\hline & & & Salt & & \\
\hline \multicolumn{3}{|c|}{ Colorant extraction : } & Kanwu & & \\
\hline \multirow[t]{2}{*}{ cool $\square$} & \multirow[t]{2}{*}{ hot } & \multirow[t]{2}{*}{$\square$} & Ash & & \\
\hline & & & Bicarbonate & & \\
\hline
\end{tabular}

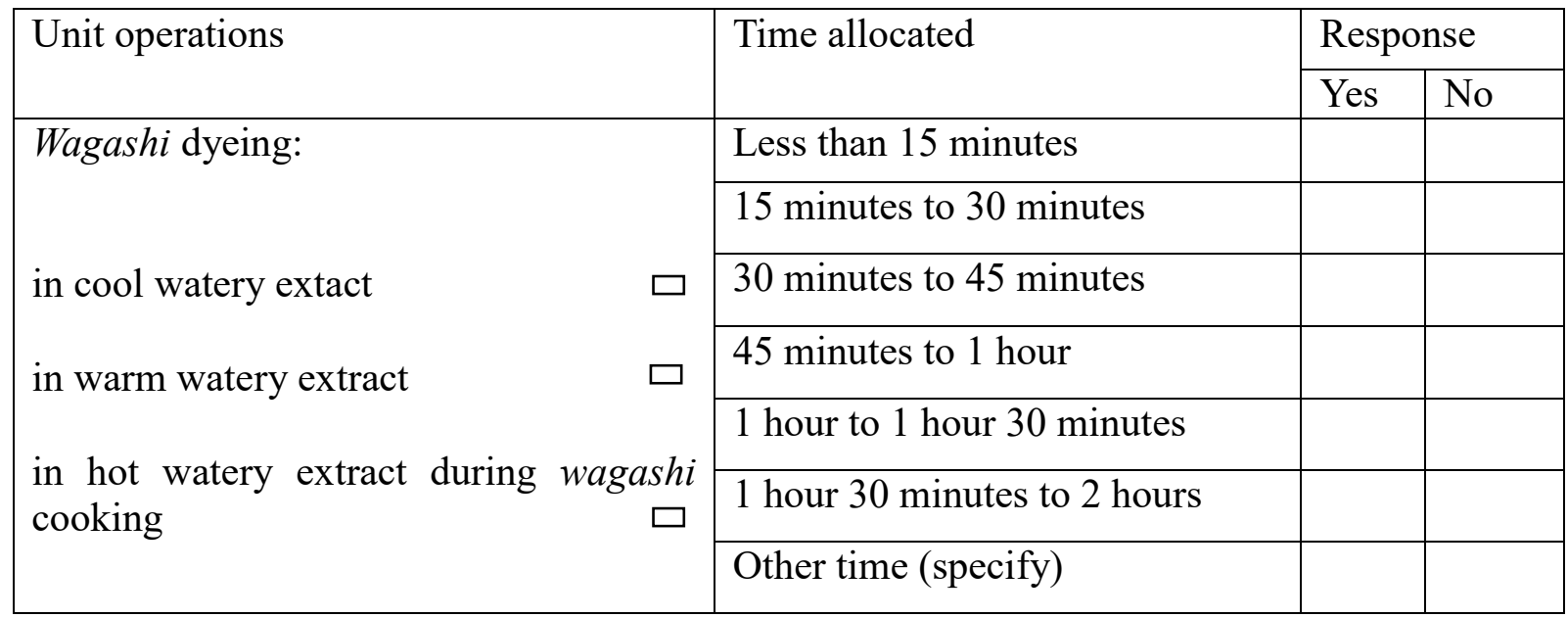

2- Does the intensity of the redness of the colorant help to reduce the time allocated to the dyeing?

$$
\text { Yes } \square \quad \text { No }
$$

3- What are the reasons that motivate the wagashi dyeing?

\begin{tabular}{|l|l|l|}
\hline Reasons & Yes & No \\
\hline Keep wagashi attractive & & \\
\hline Hamper visual detection of spoiling of wagashi and standardise the colour & & \\
\hline Delays the wagashi spoiling & & \\
\hline Delay the fermentation of wagashi & & \\
\hline Others : (specify) & & \\
\hline
\end{tabular}


4- How do you appreciate the shelf-life of the following wagashi?

\begin{tabular}{|l|lllll|}
\hline & Indication of the shelf-life & & \\
\hline $\begin{array}{l}\text { Non-dyed wagashi bought from the } \\
\text { Fulani }\end{array}$ & low $\square \quad$ moderate & $\square$ & long & $\square$ \\
\hline $\begin{array}{l}\text { Non-dyed wagashi cooked with salt } \\
\text { and kanwu }\end{array}$ & low $\square$ & moderate & $\square$ & long & $\square$ \\
\hline $\begin{array}{l}\text { Wagashi cooked with salt, kanwu } \\
\text { and dyed with sorghum biocolorant }\end{array}$ & low $\square$ & moderate & $\square$ & long & $\square$ \\
\hline
\end{tabular}

5- In slum times, what is the longest shelf-life have you experienced for dyed wagashi ?

\begin{tabular}{|l|llllll|}
\hline & Longest shelf-life & & & \\
& & & & & & \\
\hline Dyed wagashi & 1 day & $\square$ & 2 days & $\square$ & 3 days & $\square$ \\
4 days & $\square$ & 5 days & $\square$ & 6 days & $\square$ \\
7 days & $\square$ & 8 days & $\square$ & 9 days & $\square$ \\
10 days & $\square$ & 11 days & $\square$ & 12 days & $\square$ \\
& More than 12 days $\square$ & & \\
\hline
\end{tabular}

6- In slum times, what is the longest shelf-life have you experienced for non-dyed wagashi?

\begin{tabular}{|l|l|lllll|}
\hline & & Longest shelf-life & & & \\
& & & & & & \\
\hline Non-dyed wagashi & 1 day & $\square$ & 2 days & $\square$ & 3 days & $\square$ \\
4 days & $\square$ & 5 days & $\square$ & 6 days & $\square$ \\
7 days & $\square$ & 8 days & $\square$ & 9 days & $\square$ \\
10 days & $\square$ & 11 days & $\square$ & 12 days & $\square$ \\
More than & 12 days & & & & \\
\hline
\end{tabular}


7- $\quad$ In slum times, what is the frequency of a repetitive cooking and dyeing

\begin{tabular}{|c|c|c|c|}
\hline & Frequency & & \\
\hline Repetitive cooking with salt and dyeing & $\begin{array}{l}1 \text { day } \square \\
4 \text { days } \square\end{array}$ & $\begin{array}{l}2 \text { days } \square \\
5 \text { days } \square\end{array}$ & $\begin{array}{l}3 \text { days } \square \\
6 \text { days } \square\end{array}$ \\
\hline Repetitive dyeing & $\begin{array}{l}1 \text { day } \square \\
4 \text { days } \square\end{array}$ & $\begin{array}{l}2 \text { days } \square \\
5 \text { days } \square\end{array}$ & $\begin{array}{l}3 \text { days } \square \\
6 \text { days } \square\end{array}$ \\
\hline
\end{tabular}

8- What size of wagashi do you sell?

small

medium

large

9- Why do you choose to sell this (or these) size (s) of wagashi?

10- Is the quantity of leaf sheaths differ according to the size of wagashi?
Yes
No

If Yes, explain:

11- Does the time allocate to the dyeing depend on the size of the wagashi?

Yes $\quad \square \quad$ No

If Yes, explain:.... 
12- Could you provide information on the inputs for wagashi dyeing and their price?

\begin{tabular}{|c|c|c|c|c|}
\hline Step & Inputs & Quantity & Price & Cost \\
\hline \multirow{8}{*}{$\begin{array}{l}\text { Cuisson } \quad \mathrm{du} \\
\text { wagashi }\end{array}$} & wagashi & & & \\
\hline & water & & & \\
\hline & kanwu & & & \\
\hline & Salt & & & \\
\hline & Plastic bags & & & \\
\hline & wood & & & \\
\hline & Others (Specify) & & & \\
\hline & Total 1 & & & \\
\hline \multirow[t]{5}{*}{$\begin{array}{l}\text { Wagashi } \\
\text { dyeing }\end{array}$} & $\begin{array}{l}\text { Sorghum leaf } \\
\text { sheaths }\end{array}$ & & & \\
\hline & water & & & \\
\hline & kanwu & & & \\
\hline & Others (Specify) & & & \\
\hline & Total 2 & & & \\
\hline
\end{tabular}

13- $\quad$ How much is dyed wagashi?

14- How much is non-dyed wagashi?

15- How much time is allocated to the following tasks?

\begin{tabular}{|l|l|}
\hline Tasks & Time allocated (minutes) \\
\hline Wagashi cooking & \\
\hline Wagashi dyeing & \\
\hline Total & \\
\hline
\end{tabular}




\section{Chapter 4}

\section{Effects of processing and storage on the stability of the red}

\section{biocolorant apigeninidin from sorghum*}

F. U. G. Akogou, A. P. P. Kayodé, H. M. W. den Besten, A. R. Linnemann, V. Fogliano

*Published as: Akogou, F. U. G., Kayodé, A. P. P., den Besten, H. M. W., Linnemann, A. R., $\&$ Fogliano, V. (2018). Effects of processing and storage on the stability of the red biocolorant apigeninidin from sorghum. LWT-Food Science and Technology, 90, 592-597. 


\begin{abstract}
A major drawback to the industrial application of many biocolorants is their instability to processing conditions, thereby limiting their use to replace artificial colorants. 3deoxyanthocyanidins have promising features to ensure colour stability in food processing conditions. This study evaluated the stability of apigeninidin, the main 3-deoxyanthocyanidin from sorghum leaf sheaths, to food processing conditions in watery extracts and in a maize porridge. Apigeninidin was not soluble at $\mathrm{pH} 5.04 \pm 0.02$. However, apigeninidin was soluble and stable at $\mathrm{pH}$ 6-10 with increased colour density and resistance to bleaching at alkaline $\mathrm{pH}$. A heat treatment of $121{ }^{\circ} \mathrm{C} / 30$ min degraded $61 \%$ of the anthocyanins. At $65{ }^{\circ} \mathrm{C}$, degradation rate of apigeninidin was four times lower at $\mathrm{pH} 9.03 \pm 0.04$ than $6.08 \pm 0.02$. Storage at room temperature promoted endothermic degradation reactions. Nevertheless, photodegradation of apigeninidin was not observed during storage. In the maize porridge, thermal stability of apigeninidin and redness were similar at $\mathrm{pH} 4-6$ whereas they were higher at $\mathrm{pH} 9.03 \pm 0.04$. In summary, the watery extract of apigeninidin from sorghum leaf sheaths showed good stability regarding common industrial processes. Nevertheless, the biocolorant's precipitation at $\mathrm{pH} 5.04 \pm 0.02$ and degradation at $\mathrm{pH} 6.08 \pm 0.02$ and $9.03 \pm 0.04$ need further investigation to optimise its industrial applications.
\end{abstract}

Keywords: Apigeninidin, heat treatment, $\mathrm{pH}$, colour density, biocolorant 


\section{INTRODUCTION}

Anthocyanins (ACY) are plant pigments with colours that range from scarlet to blue (Wallace \& Giusti, 2015). In solution, ACY are a mixture of the coloured (i.e. the flavylium cation and quinoidal base) and colourless forms (i.e. the carbinol pseudobase and the chalcone) (Brouillard, 1982). The proportion of flavylium cation, quinoidal base, carbinol pseudobase and chalcone at equilibrium in an ACY solution are a function of ACY structures and processing conditions (viz. $\mathrm{pH}$, light exposure and temperature) (Mazza \& Brouillard, 1987). In general, an increasing $\mathrm{pH}$ leads to (a) an increasing hydration of the flavylium cation into carbinol pseudobase and (b) increasing tautomerisation of carbinol pseudobase into chalcone (Brouillard, 1982). Consequently, the proportion of chalcone would be higher than that of the flavylium cation for $\mathrm{pH}$ values above 3 (Brouillard, 1982). However, the $\mathrm{pH}$ limit for a dominant proportion of chalcone is higher for ACY with a methoxylation or a glycosylation (Brouillard, 1982). In addition, a high temperature during processing or storage increases the rate of endothermic reactions (e.g. hydration of the flavylium cation and tautomerisation of the carbinol pseudobase) (Brouillard, 1982). Furthermore, light exposition of ACY leads to photodegradation of flavylium cations into colourless forms (i.e. the carbinol pseudobase and chalcone) (Dyrby et al., 2001).

The 3-deoxyanthocyanidins are a particular class of ACY because the deprotonation constant of its flavylium cation is higher than for the hydration. Consequently, a solution of 3deoxyanthocyanidins stays coloured at high $\mathrm{pH}$. The 3-deoxyanthocyanidins have the interest of the food industry for their resistance to (a) pH changes (Ojwang \& Awika, 2008), (b) bleaching additives (e.g. sulphites) (Ojwang \& Awika, 2010), and (c) ring fission during heat treatment (Yang et al., 2014). Moreover, they show a better colouring efficiency than the majority of the anthocyanins (Awika et al., 2004) and their colour stability improves in the presence of phenolic acids (Ojwang \& Awika, 2008). Most experiments on the stability of 3-deoxyanthocyanidins were with non-food grade solvents such as ethanol, methanol, hydroalcoholic solutions, water acidified with $\mathrm{HCl}$ or 70\% aqueous acetone (Awika et al., 2004; Ojwang \& Awika, 2008; Kayodé et al., 2012). Limited data exist on the stability of apigeninidin in watery extracts as commonly applied by traditional users of sorghum biocolorant in West Africa. This study evaluated (a) the degradation of sorghum total ACY in relation to heat treatments and storage conditions (light exposure, storage temperature), (b) the effect of a food acidulant (viz. citric acid) and alkaline conditions $(\mathrm{NaOH})$ on apigeninidin solubility and degradation, (c) the thermal degradation 
kinetics and the resistance to bleaching of apigeninidin in relation to the $\mathrm{pH}$ of the watery extract and (d) the apigeninidin degradation and colour properties at different $\mathrm{pH}$ values in a food matrix, namely maize porridge.

\section{MATERIAL AND METHODS}

\section{Materials}

Dried dye sorghum (Sorghum bicolor) leaf sheaths and kanwu, an alkaline rock containing carbonate and bicarbonate salts (Madodé, 2012) used by local users as an extraction aid, were bought at the market of Dassa-zoumè in Benin and ground into powder using a miller (Coffee Bean and Spice Mill Grinder Model \#843, Moulinex). Maize grains (Zea mays) were purchased from the market of Abomey-Calavi in Benin, cleaned and milled into flour using a miller (RotorMill Pulvrisette-14, Idar-Oberstein, Germany) equiped with a $0.2 \mathrm{~mm}$ sieve as an ingredient for making maize porridge. Solutions of $1 \mathrm{~N}$ of citric acid (Sigma-Aldrich, Netherlands) and $1 \mathrm{~N}$ hydroxide sodium (Merck, Germany) were used as acidic and alkaline solutions, respectively.

\section{Apigeninidin extraction procedures}

Sorghum alkaline watery extract (SAWE) and sorghum hot aqueous extract (SHAE) were produced by cool alkaline and hot aqueous extraction, respectively (Akogou et al., 2018). These two watery extraction methods are the most common traditional extraction procedures in Benin. Alkaline extraction was conducted by mixing $11.1 \mathrm{~g}$ of sorghum leaf sheath powder, $1.5 \mathrm{~g}$ of kanwu and $1000 \mathrm{~mL}$ of water and strirring for $20 \mathrm{~min}$ at room temperature. For hot aqueous extraction, $11.1 \mathrm{~g}$ of sorghum leaf sheath powder and $1000 \mathrm{~mL}$ of water were mixed and heated with a magnetic heating plate (model FB 15010 , Fischer Scientific) from $21.5^{\circ} \mathrm{C}$ to $86{ }^{\circ} \mathrm{C}$ and then cooled down in an ice bucket. Both watery extracts were filtered with $2.5 \mu \mathrm{m}$ filter paper (Whatman, GE Healthcare UK Limited, UK) to remove sorghum residues. The $\mathrm{pH}$ of the SAWE and the SHAE were $8.67 \pm 0.14$ and $7.07 \pm 0.04$, respectively. 


\section{Thermal treatment and storage of the watery extracts}

Volumes of $6 \mathrm{~mL}$ of SAWE and SHAE were transferred in glass tubes and subjected to various heat treatments, i.e. $65^{\circ} \mathrm{C} / 30 \mathrm{~min}, 95^{\circ} \mathrm{C} / 30 \mathrm{~min}$ and $121^{\circ} \mathrm{C} / 30 \mathrm{~min}$. A water bath (Memmert WNE 14, Schwabach, Germany) and an autoclave (Timo, Pbi International, Italy) were used to apply (a) $65^{\circ} \mathrm{C} / 30 \mathrm{~min}$ and $95^{\circ} \mathrm{C} / 30 \mathrm{~min}$ and (b) $121^{\circ} \mathrm{C} / 30 \mathrm{~min}$, respectively. The water bath was preheated to $65{ }^{\circ} \mathrm{C}$ and $95^{\circ} \mathrm{C}$ before applying the heat treatments. After the heat treatments, the tubes were cooled down in a cold water bath. Two independent duplicates of SAWE and SHAE were subjected to heat treatments. Next the stability of ACY to various storage conditions was evaluated by keeping independent duplicate extracts for 18 days (i) in the dark at room temperature $\left(26-35{ }^{\circ} \mathrm{C}\right.$ ) (Adinsi et al., 2014), (ii) in the dark under refrigeration at $4{ }^{\circ} \mathrm{C}$, and (iii) in ambient light at room temperature $\left(26-35^{\circ} \mathrm{C}\right.$ ) (Adinsi et al., 2014). Two tubes of SAWE and SHAE were taken (a) before and after treatment and (b) during storage for measurement of the total ACY content and the total colour density (TCD).

The total ACY content was measured using the $\mathrm{pH}$ differential method by Cao et al. (2008). The total ACY was measured only in the $\mathrm{pH} 1$ buffer because the main ACY in sorghum extract (i.e. apigeninidin) is not colourless in a pH 4.5 buffer (Awika et al., 2004). Wavelengths of 470 and $700 \mathrm{~nm}$ were used for apigeninidin and haze correction, respectively. The total ACY content was calculated using the following Equation (1):

$$
\text { Total ACY content (apigeninidin equivalent } \mathrm{mg} \mathrm{L}^{-1} \text { ) }=\frac{\mathrm{A} \times 290.69 \times \mathrm{DF} \times 10^{3}}{\varepsilon_{a} \times \mathrm{l}}
$$

where $\mathrm{A}=\left(\mathrm{A}_{470 \mathrm{~nm}}-\mathrm{A}_{700 \mathrm{~nm}}\right) p H_{1.0} ; 290.69$ : molecular weight of apigeninidin chloride $(\mathrm{g}$ $\mathrm{mol}^{-1}$ ); DF: dilution factor; $10^{3}$ : conversion factor from $\mathrm{g}$ to $\mathrm{mg} ; \varepsilon_{\mathrm{a}}:$ molar absorptivity of apigeninidin chloride $\left(\mathrm{L} \mathrm{mol}^{-1} \mathrm{~cm}^{-1}\right)$; 1: path length (which is $1 \mathrm{~cm}$ ). The molar absorptivity of apigeninidin chloride was determined by the method of Cao et al. (2008) with an apigeninidin chloride standard (Extrasynthese, Genay, France).

The TCD was determined according to Turfan et al. (2011). Wavelengths of 420, 470 and $700 \mathrm{~nm}$ were used for brown pigments, apigeninidin and haze correction, respectively.

The TCD was calculated using Equation (2):

$$
\mathrm{TCD}=\left[\left(\mathrm{A}_{420}-\mathrm{A}_{700}\right)+\left(\mathrm{A}_{470}-\mathrm{A}_{700}\right)\right]_{\text {non-treated sample }} \times \mathrm{DF}
$$


where DF: dilution factor.

The apigeninidin content and the TCD were measured using a Spectrophotometer (SmartSpec Plus spectrophotometer, Bio Rad, USA).

\section{pH adjustment of the watery extract}

Acidic (citric acid $1 \mathrm{~N}$ ) and alkaline (hydroxide sodium $1 \mathrm{~N}$ ) solutions were used to adjust the $\mathrm{pH}$ of independent duplicate samples of SAWE $(50 \mathrm{~mL}, \mathrm{pH} 8.67)$ to $5.04 \pm 0.02,6.08 \pm 0.02$, $10.03 \pm 0.03,11.04 \pm 0.03$ and $12.07 \pm 0.04$. Samples were poured in $50 \mathrm{~mL}$ polypropylene tubes (Cellstar, Greiner Bio-One, Frickenhausen, Germany), kept at room temperature for 30 min and centrifuged at $3000 \mathrm{rpm}$ at $4{ }^{\circ} \mathrm{C}$ for $30 \mathrm{~min}$ with a centrifuge (Heraeus Multifuge X3R, Thermo Fisher Scientific, UK). Next, the supernatant was collected and the pellet was suspended in methanol. The plain extract was used when no pellet had been formed. The apigeninidin content, its molar adsorptivity and the formation of phenolic acids as degradation products in the supernatants, the in methanol suspended pellets and the plain extracts were determined by HPLC. An ultimate 3000 RS High Performance Liquid Chromatography (HPLC) system equipped with a Diode Array Detector DAD-3000 RS (Thermo Scientific Dionex, Amsterdam, the Netherlands) and a quaternary pump LPG- 3000 RS (Thermo Scientific Dionex) was used. Standards of apigeninidin (Extrasynthese, France), 4-hydroxybenzoic acid (Sigma Aldrich, Netherlands) and p-coumaric acid (Sigma Aldrich, Netherlands) were used for identification and quantification. Compounds were separated with a Polaris C18-A column $(150 \times 4.6 \mathrm{~mm}$, Varian, CA, USA $)$ at a volumetric flow rate of $1 \mathrm{~mL} \mathrm{~min}^{-1}$ with two mobile phases, i.e. formic acid (10\%) in milli-Q water (A) and methanol (100\%) (B). The elution gradient of B was: 0 to $20 \mathrm{~min}$, from 5\% to $60 \%$ B; 20 to $25 \mathrm{~min}$, from $60 \%$ to $100 \% \mathrm{~B} ; 25$ to $30 \mathrm{~min}$ with $100 \% \mathrm{~B} ; 30$ to $31 \mathrm{~min}$ from $100 \%$ to $5 \% \mathrm{~B} ; 31$ to $35 \mathrm{~min}$ with 5\% B. Apigeninidin, 4-hydroxybenzoic acid and $p$-coumaric acid were measured at 480, 260 and $280 \mathrm{~nm}$, respectively.

The molar absorptivity of apigeninidin was calculated using Equation (3) (Locatelli et al., 2011):

$$
\varepsilon_{\mathrm{b}}=\frac{\mathrm{A} \times \mathrm{f} \times 255.24}{\mathrm{l} \times \mathrm{c} \times \mathrm{v} \times 10^{-6}}
$$

where $\varepsilon_{b}$ : molar absorptivity $\left(\mathrm{L} \mathrm{mol}^{-1} \mathrm{~cm}^{-1}\right)$; A: peak area recorded by HPLC (AU min); f: volumetric flow rate $\left(\mathrm{L} \mathrm{min}^{-1}\right)$; 255.24: molecular weight of apigeninidin $\left(\mathrm{g} \mathrm{mol}^{-1}\right)$; 1: optical path 
length of the flow cell (which is $1 \mathrm{~cm}$ ); $\mathrm{c}$ : concentration of apigeninidin $\left(\mathrm{mg} \mathrm{L}^{-1}\right) ; 10^{-6}$ : conversion factor from $\mathrm{mg} \mathrm{L}^{-1}$ to $\mathrm{g} \mathrm{mL}^{-1}$; v: volume injected $(\mathrm{mL})$.

\section{Degradation of apigenindin in watery extracts at different $\mathrm{pH}$}

Four independent replicates of SAWE were prepared. The $\mathrm{pH}$ was adjusted to $6.08 \pm 0.02$ and $9.03 \pm 0.04$ as described above, after which $6 \mathrm{~mL}$ samples were transferred to glass tubes and stored at $4{ }^{\circ} \mathrm{C}$ overnight ( 16 hours). Next, the kinetic degradation of the extracts was performed at $65{ }^{\circ} \mathrm{C}$ using a block heater (Labtherm Liebisch, Bielefeld, Germany). Two tubes of SAWE at pH $6.08 \pm 0.02$ and $9.03 \pm 0.04$ were withdrawn at time intervals from 0 to $60 \mathrm{~min}$ to measure the apigeninidin content and the TCD as described above. In addition the polymeric colour (PC) and the \% PC were determined on the watery extracts treated with bisulphite, see Equations (4) and (5) (Turfan et al., 2011). Wavelengths of 420, 470 and $700 \mathrm{~nm}$ were used for brown pigments, apigeninidin and haze correction, respectively. The experiment was performed four times with independent samples. The thermal degradation of apigeninidin was described with the natural logarithm scale using the Weibull model, see Equation (6).

$$
\begin{gathered}
\mathrm{PC}=\left[\left(\mathrm{A}_{420}-\mathrm{A}_{700}\right)+\left(\mathrm{A}_{470}-\mathrm{A}_{700}\right)\right]_{\text {treated sample }} \times \mathrm{DF} \\
\% \mathrm{PC}=\frac{\mathrm{PC}}{\mathrm{TCD}} \times 100 \\
\ln \mathrm{C}_{\mathrm{t}}=\ln \mathrm{C}_{0}-\left(\frac{\mathrm{t}}{\delta}\right)^{\beta}
\end{gathered}
$$

where, $\mathrm{C}_{\mathrm{t}}$ : concentration of degraded apigeninidin $\left(\mathrm{mg} \mathrm{L}^{-1}\right) ; \mathrm{C}_{0}$ : initial apigeninidin content $(\mathrm{mg}$ $\left.\mathrm{L}^{-1}\right) ; \delta$ : the inverse of the kinetic rate constant $\left(\mathrm{min}^{-1}\right) ; \beta$ : shape constant, which defines the degree of concavity of the curve and t: time (min).

\section{Combined effect of heat treatment and $\mathrm{pH}$ adjustment in a food matrix}

Two independent replicates of SAWE and solution of kanwu (SK) (1.5 $\mathrm{g} \mathrm{L}^{-1}$ in milli-Q water) were prepared and adjusted to $\mathrm{pH} 4.09 \pm 0.19,5.04 \pm 0.02,6.08 \pm 0.02$ and $9.03 \pm 0.04$ as described above. Maize flour $(81 \mathrm{~g})$ was added to $810 \mathrm{~mL}$ of the $\mathrm{pH}$ adjusted SAWE and SK. The mix was cooked using a thermomixer (Vorwerk, Wuppertal, Germany). The samples of maize porridge 
cooked with $\mathrm{pH}$ adjusted SK were used as control. The temperature of the cooking programme was set as follows: from 23 to $95{ }^{\circ} \mathrm{C}$ during the first $10 \mathrm{~min}$ and cooking at $95{ }^{\circ} \mathrm{C}$ during the next $10 \mathrm{~min}$. Next, the samples were cooled down (i) at room temperature to measure colour and dry matter and (ii) with liquid nitrogen, freeze-dried at $-55^{\circ} \mathrm{C} / 0.72$ mbar (using an Alpha 1-4 LD plus freeze-dryer, Marin Christ, Germany) and milled by impact and friction (mixer mill MM400, Retsch, Haan, Germany) for extraction and quantification of apigeninidin. Colour parameters $\left(L^{*}\right.$, $\left.a^{*}, b^{*}\right)$ were measured with a HunterLab Colorflex EZ spectrophotometer (Reston, VA, USA) (illuminant D 65 and $10^{\circ}$ observer) and the chroma $\left(C^{*}\right)$ and the hue $\left(h^{\circ}\right)$ were calculated.

\section{Statistical analysis}

Data on the total ACY, apigeninidin and phenolic acids (4-hydroxybenzoic acid and $p$-coumaric acid), TCD, PC, \%PC, colour parameters $\left(L^{*}, C^{*}, h^{\circ}\right)$ were analysed with SPSS 23.0 (SPSS Inc, Chicago, IL, USA). One way variance analysis (ANOVA) on the means (or on the mean ranks when the normality or homogeneity of variance failed) followed by post hocs (Duncan or MannWhitney pairwise tests) were applied to detect differences between treatments ( $\mathrm{pH}$, heat treatment and time exposure).

The parameters of the Weibull model $\left(\ln \mathrm{C}_{0}, \delta\right.$ and $\left.\beta\right)$ and their standard errors were estimated with the macro Solver Aid in Excel 2010. The f-value of the model was determined with Equation (7) (den Besten et al., 2006). The f-value was compared to the F-value table for $\alpha=0.05$ as shown in Equation (8) (den Besten et al., 2006).

$$
\mathrm{f}-\text { value }=\frac{\mathrm{MSE}_{\text {model }}}{\mathrm{MSE}_{\text {data }}}
$$

where, MSE $E_{\text {model: }}$ mean square error of the model; $\mathrm{MSE}_{\mathrm{data}}$ : mean square error of the data

$$
\mathrm{F}_{\mathrm{DF}_{\text {data }}}^{\mathrm{DF}}=\mathrm{F}_{\mathrm{n}-\mathrm{m}}^{\mathrm{n}-\mathrm{s}}
$$

where $\mathrm{DF}_{\text {model }}$ : degrees of freedom of the model; $\mathrm{DF}_{\text {data: }}$ degrees of freedom of the data; $\mathrm{n}$ : number of data points, $\mathrm{m}$ : the number of time points; s: number of parameters of the model. 


\section{RESULTS AND DISCUSSION}

\section{Stability of total ACY in dye sorghum extract to heat treatment and storage conditions}

Total ACY losses of $17-18 \%, 59-66 \%$ and $60-61 \%$ were measured after $65^{\circ} \mathrm{C} / 30 \mathrm{~min}, 95{ }^{\circ} \mathrm{C} /$ $30 \mathrm{~min}$ and $121^{\circ} \mathrm{C} / 30 \mathrm{~min}$ heat treatments, respectively (Figure 1). The percentage of total ACY that degraded due to the heat treatments was comparable for both types of watery extracts, although the total ACY differed $\left(323.5 \pm 11.8 \mathrm{mg} \mathrm{L}^{-1}\right.$ and $181.0 \pm 42.0 \mathrm{mg} \mathrm{L}^{-1}$ for SAWE and SHAE, respectively) as well as the $\mathrm{pH}$ values $(8.67 \pm 0.14$ and $7.07 \pm 0.04$ for $\mathrm{SAWE}$ and $\mathrm{SHAE}$, respectively). According to Brouillard et al. (1982), the quinoidal bases are the dominant coloured forms of 3-deoxyanthocyanidins at $\mathrm{pH}$ 6. The $\mathrm{pH}$ of the SAWE and SHAE also suggested the quinoidal bases as the major forms of ACY at high $\mathrm{pH}$ (7.07 to 8.67). Apparently, the initial total ACY content and the shift from neutral to alkaline $\mathrm{pH}$ did not affect $(\mathrm{p}=0.4$ for 65 ${ }^{\circ} \mathrm{C} / 30 \mathrm{~min}$ and $\mathrm{p}=0.1$ for $95^{\circ} \mathrm{C} / 30 \mathrm{~min}$ and $121^{\circ} \mathrm{C} / 30 \mathrm{~min}$ ) the stability of ACY in relation to heat treatment. A previous study showed a loss of $80 \%$ of the anthocyanins at $100{ }^{\circ} \mathrm{C} / 30 \mathrm{~min}$ (Hiemori et al., 2009). In this respect, the ACY from sorghum extract performed much better at a neutral and alkaline $\mathrm{pH}$. Data showed that sorghum extract can successfully be used in foods that require sterilisation treatments at $\mathrm{pH} 7.07 \pm 0.04$ and $8.67 \pm 0.14$, confirming the good thermal stability of apigeninidin (Yang et al., 2014) and providing additional information on thermal stability at alkaline $\mathrm{pH}$.

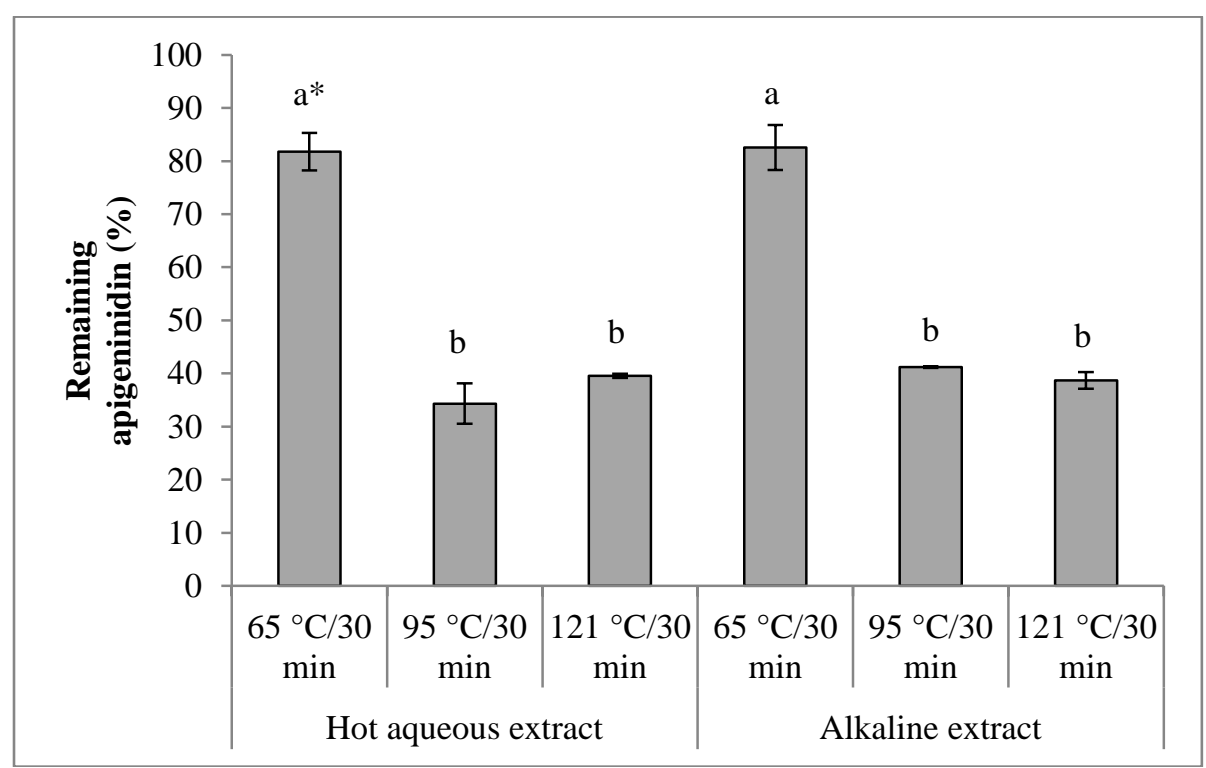

*Bars with the same letters are not significantly different at 5\%

Figure 1. Stability of sorghum extracts to the most common heat treatments. 
Figure 2 shows the stability of total ACY during storage. A general decrease of the apigeninidin content was observed during storage under ambient light and in the dark at room temperature (25$\left.36{ }^{\circ} \mathrm{C}\right)$, as well as in the dark under refrigerated conditions $\left(4^{\circ} \mathrm{C}\right)$. After 18 days of storage, the decreases of total ACY in SAWE and SHAE were (a) $71.9 \%$ and $50.6 \%$ under ambient light, respectively, (b) $71.4 \%$ and $48.5 \%$ in the dark at room temperature, respectively and (c) $44.8 \%$ and $24.9 \%$ in the dark under refrigerated conditions, respectively. At room temperature, light conditions apparently had no influence on the apigeninidin decrease in SAWE or SHAE. Photodegradation of ACY could occur through the hydration of the flavylium cation into carbinol pseudobase (Dyrby et al., 2001). On the contrary, the high pH of SAWE and SHAE (8.67 \pm 0.14 and $7.07 \pm 0.04)$ promoted the formation of quinoidal base, which might not be involved in the photodegradation of ACY. Ojwang \& Awika (2008) also reported good stability of flavylium cation of apigeninidin with only $25 \%$ loss after 15 days of storage under fluorescent light at 25 ${ }^{\circ} \mathrm{C}$. The absence of increased degradation in extracts exposed to ambient light is advantageous since it implies that dye sorghum can be applied to foods and non-food products commonly exposed to light because common anthocyanins (i.e. glycosides of cyanidin and delphinidin) could lose more than $90 \%$ of the initial concentration of colorant after 15 days under light conditions (Baublis et al., 1994). The alkaline extract appeared to be particularly sensitive to storage at room temperature. Storage at room temperature $\left(26-35{ }^{\circ} \mathrm{C}\right)$ increased the degradation of ACY due to its higher reactivity at high temperature (Kırca \& Cemeroğlu, 2003; Alighourchi \& Barzegar, 2009). Refrigerated storage slowed down the degradation of ACY. The reactions leading to the formation of the carbinol pseudobase and chalcone are known as endothermic (Brouillard, 1982). Therefore, storage at refrigeration temperature $\left(4{ }^{\circ} \mathrm{C}\right)$ would retard the endothermic reactions leading to ACY degradation. 


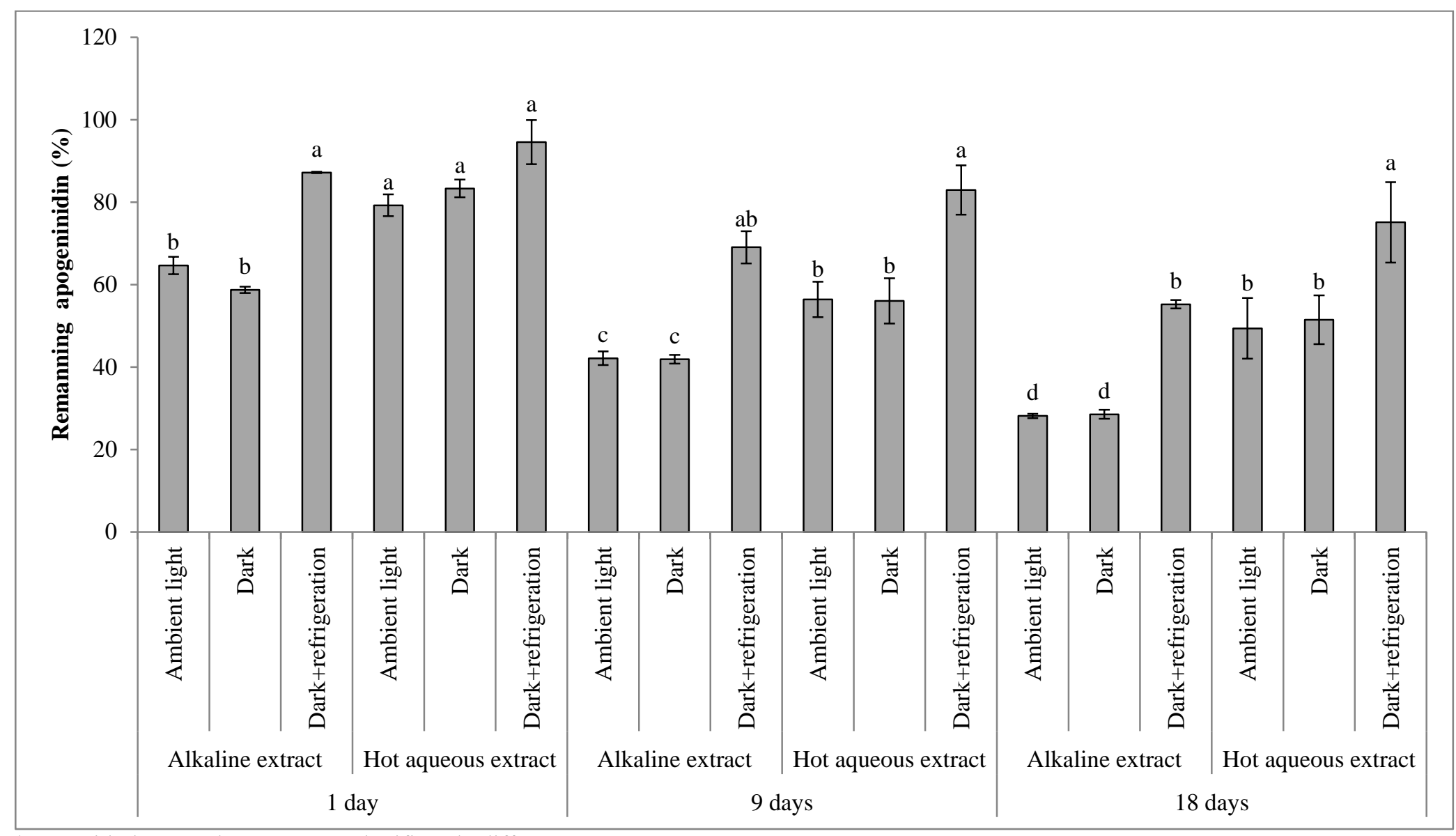

*Bars with the same letters are not significantly different at 5\%

Figure 2. Stability of pasteurised extracts to light and temperature during storage. 


\section{Effect of pH adjustment}

The apigeninidin content of dye extracts was constant at $\mathrm{pH}$ 6-10 (Figure 3), whereas its molar absorptivity did not change $(\mathrm{p}=0.06)$ at $\mathrm{pH}$ 5-12 $\left(27629.5 \pm 85.7 \mathrm{~L} \mathrm{~mol}^{-1} \mathrm{~cm}^{-1}\right)$. Nevertheless, data reported in Table 1 shows that the use of an acidulant resulted in a lower TCD at $\mathrm{pH} 6.08 \pm 0.02$ than at $\mathrm{pH} 9.03 \pm 0.04$, implying that $\mathrm{pH}$ might affect the colour density of the watery extract of apigeninidin. A stable ACY molar absorptivity suggests a stable colour intensity (Torskangerpoll \& Andersen, 2005). However, despite its stable molar absorptivity, the colour density of apigeninidin extract was not stable over the $\mathrm{pH}$ range tested. The phenolic acid content might affect the colour density of the apigeninidin watery extract as they could enhance the colour, contributing to a high TCD at high pH (Ojwang \& Awika, 2008). Conversely, the oxidation of organic acids (e.g. citric acid) and their condensation with other phenolic compounds may occur at low $\mathrm{pH}$ values, contributing to a low colour intensity at pH 6.08 \pm 0.02 (Kokkaew et al., 2015).

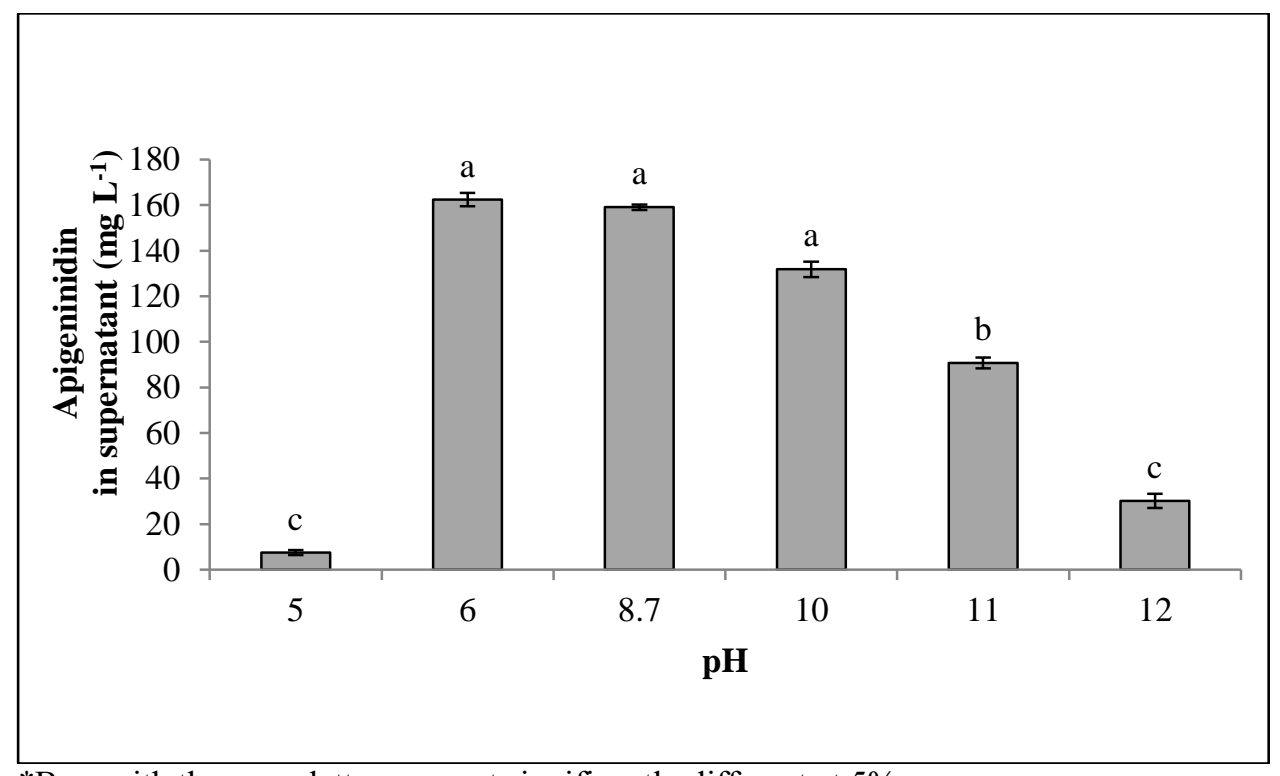

*Bars with the same letters are not significantly different at 5\%

Figure 3. Effect of the $\mathrm{pH}$ adjustment on apigeninidin measured in solution at room temperature. 
The use of an acidulant at $\mathrm{pH} 5.04 \pm 0.02$ resulted in an apigeninidin precipitation with the formation of two phases: (i) a supernatant containing only 5\% of the initial apigeninidin and (ii) a pellet rich in apigeninidin. HPLC analysis showed that the pellet contained apigeninidin with a purity of $100 \%$. In addition, phenolic acids (viz., 4-hydroxybenzoic and $p$-coumaric acid) were absent at a detection limit of $1.95 \mu \mathrm{g} \mathrm{mL} \mathrm{m}^{-1}$. Instead of the bleaching of apigeninidin in the presence of acidulants like acid ascorbic at pH 5 reported by Ojwang \& Awika (2008), a loss of net charge leading to an apigeninidin precipitation in watery extract at $\mathrm{pH} 5$ provided additional information on the effect of acid $\mathrm{pH}$ on apigeninidin extract. Precipitation of apigeninidin at $\mathrm{pH} 5.04 \pm 0.02$ might limit its application in acidic drinks $(\mathrm{pH} \leq 5)$. On the contrary, an alkaline $\mathrm{pH}$ resulted in the degradation of apigeninidin. At $\mathrm{pH} 11.04 \pm 0.03$ and $12.07 \pm 0.04$, the apigeninidin concentration decreased by $44.1 \%$ and $81.4 \%$, respectively, compared with the extract at $\mathrm{pH} 6.08 \pm 0.02$ (Figure 3). According to literature, apigeninidin could be converted into phenolic acids at alkaline pH (Yang et al., 2014). Therefore alkaline extracts were analysed by HPLC. Parallel to the decrease of apigeninidin, an increase in the phenolic acid content of the extract was found. From $\mathrm{pH} 6.08 \pm 0.02$ to $12.07 \pm 0.04$, the concentrations of 4-hydroxybenzoic acid and p-coumaric acid increased 3.7 and 1.7 fold, respectively. Nevertheless, only 3.9 and $0.53 \%$ of the degraded apigeninidin were converted in 4-hydroxybenzoic acid and $p$-coumaric acid, respectively. This suggests that other phenolic acids might have been formed too.

The stability of apigeninidin and colour to heat treatment in a semisolid food matrix (i.e. a maize porridge) at different $\mathrm{pH}$ is reported in Table 2. The apigeninidin content of the porridge did not differ at $\mathrm{pH}$ 4-6 $(\mathrm{p}=0.2)$, whereas it was higher at $\mathrm{pH} 9.03 \pm 0.04$. Furthermore, the colour of the porridge was comparable at $\mathrm{pH} 4-6$ whereas hue $\left(h^{\circ}\right)$ and lightness $\left(L^{*}\right)$ were smaller at $\mathrm{pH} 9.03 \pm 0.04$. In other words, the porridge looked more red at $\mathrm{pH} 9.03 \pm 0.04$ than at $\mathrm{pH} 4-6$. Consequently, the increased redness of the porridge and the higher concentration of apigeninidin at high $\mathrm{pH}$ might have resulted from (a) the higher TCD of the quinoidal forms of apigeninidin and (b) its higher resistance to heat treatment, respectively. 
Table 1. Effect of heat treatment $\left(65^{\circ} \mathrm{C}\right)$ on total colour density and polymeric colour of sorghum biocolorant at $\mathrm{pH} 6.08$ and 9.03

\begin{tabular}{|c|c|c|c|c|c|c|}
\hline \multirow{2}{*}{$\begin{array}{l}\text { Time } \\
(\min )\end{array}$} & \multicolumn{3}{|c|}{ pH 6.08} & \multicolumn{3}{|c|}{ pH 9.03 } \\
\hline & TCD* & $\mathrm{PC}$ & $\% \mathrm{PC}$ & TCD & $\mathrm{PC}$ & $\% \mathrm{PC}$ \\
\hline$\overline{0}$ & $12.5 \pm 1.6 \mathrm{a}$ & $3.9 \pm 0.5 \mathrm{a}$ & $31.0 \pm 0.2 \mathrm{a}$ & $45.4 \pm 1.7 \mathrm{a}$ & $7.7 \pm 0.4 \mathrm{a}$ & $17.0 \pm 0.5 \mathrm{a}$ \\
\hline 2.5 & $13.0 \pm 1.7 \mathrm{a}$ & $\begin{array}{l}4.2 \pm 0.7 \\
\mathrm{ab}\end{array}$ & $32.4 \pm 1.6 \mathrm{ab}$ & $44.8 \pm 1.3 \mathrm{ab}$ & $7.9 \pm 0.5 \mathrm{a}$ & $17.7 \pm 0.7 \mathrm{ab}$ \\
\hline 5 & $13.1 \pm 2.2 \mathrm{a}$ & $\begin{array}{l}4.2 \pm 0.7 \\
\mathrm{ab}\end{array}$ & $31.8 \pm 1.6 \mathrm{ab}$ & $44.5 \pm 1.0 \mathrm{ab}$ & $\begin{array}{l}8.1 \pm 0.5 \\
\text { ab }\end{array}$ & $18.2 \pm 0.8 \mathrm{ab}$ \\
\hline 10 & $12.9 \pm 1.9 \mathrm{a}$ & $\begin{array}{l}4.3 \pm 0.6 \\
a b\end{array}$ & $33.0 \pm 0.9 \mathrm{~b}$ & $44.2 \pm 1.5 \mathrm{ab}$ & $\begin{array}{l}8.2 \pm 0.5 \\
\text { abc }\end{array}$ & $18.5 \pm 0.8 \mathrm{bc}$ \\
\hline 20 & $13.6 \pm 1.3 \mathrm{a}$ & $\begin{array}{l}4.5 \pm 0.5 \\
\mathrm{ab}\end{array}$ & $32.8 \pm 1.1 \mathrm{~b}$ & $43.0 \pm 1.5 \mathrm{bc}$ & $\begin{array}{l}8.4 \pm 0.5 \\
\text { abc }\end{array}$ & $19.6 \pm 0.8 \mathrm{~cd}$ \\
\hline 30 & $12.9 \pm 1.1 \mathrm{a}$ & $\begin{array}{l}4.5 \pm 0.3 \\
\mathrm{ab}\end{array}$ & $34.6 \pm 0.8 \mathrm{c}$ & $42.6 \pm 1.3 \mathrm{bc}$ & $\begin{array}{l}8.5 \pm 0.6 \\
\text { abc }\end{array}$ & $20.0 \pm 0.9 \mathrm{~d}$ \\
\hline 40 & $13.4 \pm 1.6 \mathrm{a}$ & $\begin{array}{l}4.7 \pm 0.5 \\
\mathrm{ab}\end{array}$ & $34.9 \pm 0.5 \mathrm{c}$ & $42.4 \pm 1.6 \mathrm{bc}$ & $\begin{array}{l}8.7 \pm 0.7 \\
\text { bc }\end{array}$ & $20.4 \pm 1.0 \mathrm{de}$ \\
\hline 50 & $12.6 \pm 1.2 \mathrm{a}$ & $\begin{array}{l}4.6 \pm 0.4 \\
\mathrm{ab}\end{array}$ & $36.9 \pm 0.1 \mathrm{~d}$ & $42.0 \pm 1.5 \mathrm{c}$ & $\begin{array}{l}8.8 \pm 0.6 \\
\mathrm{abc}\end{array}$ & $21.0 \pm 0.9 \mathrm{de}$ \\
\hline 60 & $12.6 \pm 1.1 \mathrm{a}$ & $4.9 \pm 0.4 \mathrm{~b}$ & $38.7 \pm 0.9 \mathrm{e}$ & $41.5 \pm 1.7 \mathrm{c}$ & $9.0 \pm 0.6 \mathrm{c}$ & $21.7 \pm 0.9 \mathrm{e}$ \\
\hline
\end{tabular}

*mean \pm standard deviation; values with the same value in the same column are not significantly different at $5 \%$. $\mathrm{TCD}$, total colour density; PC, polymeric colour; \% $\mathrm{PC}$, percentage of polymeric colour 


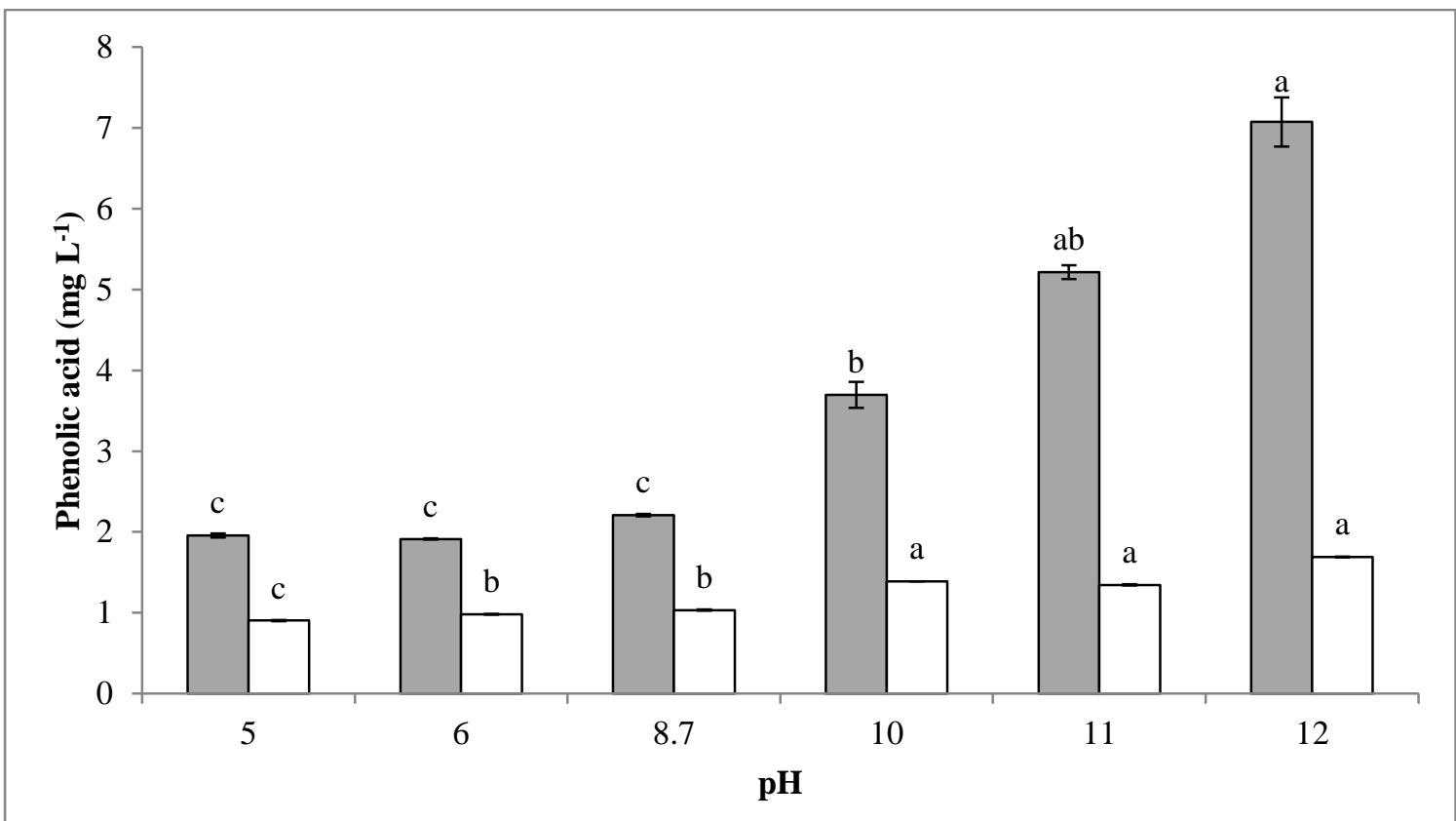

*Bars with the same colour and the same letters are not significantly different at $5 \%$.

Figure 4. Effect of $\mathrm{pH}$ on the concentration of 4-hydroxydenzoic acid ( $\square$ ) and $p$-coumaric acid ( $\square$ ) in sorghum colorant.

Table 2. Apigeninidin content and colour in cooked maize porridge

\begin{tabular}{lllll}
\hline pH & $\begin{array}{l}\text { Apigeninidin } \\
\text { content }\left(\mathbf{m g ~ g}^{-1} \mathbf{~ D M}\right)\end{array}$ & $\boldsymbol{L}^{*}$ & $\boldsymbol{C}^{*}$ & $\boldsymbol{h}^{\circ}$ \\
& $1.3 \pm 0.0 \mathrm{a}$ & $23.7 \pm 0.3 \mathrm{~b}$ & $33.3 \pm 0.5 \mathrm{a}$ & $38.0 \pm 0.8 \mathrm{~b}$ \\
\hline $4.09(\mathrm{n}=2)$ & $0.8 \pm 0.0 \mathrm{a}$ & $24.2 \pm 0.1 \mathrm{~b}$ & $30.5 \pm 0.1 \mathrm{a}$ & $34.8 \pm 0.0 \mathrm{~b}$ \\
$5.04(\mathrm{n}=2)$ & $0.8 \pm 0.0 \mathrm{a}$ & $23 \pm 0.3 \mathrm{~b}$ & $28.8 \pm 0.1 \mathrm{a}$ & $33.7 \pm 0.3 \mathrm{~b}$ \\
$6.08(\mathrm{n}=2)$ & $1.9 \pm 0.2 \mathrm{~b}$ & $13.6 \pm 0.6 \mathrm{a}$ & $30.6 \pm 0.3 \mathrm{a}$ & $27.9 \pm 0.3 \mathrm{a}$ \\
$9.03(\mathrm{n}=2)$ & & &
\end{tabular}

*mean \pm standard deviation; values with the same value in the column are not significantly different at $5 \%$. 


\section{Kinetic degradation of sorghum biocolorant as related to $\mathrm{pH}$}

Figure 5 shows the kinetic degradation of sorghum biocolorant at $65{ }^{\circ} \mathrm{C}$ and the fitted data. The degradation is lower at $\mathrm{pH} 9.03 \pm 0.04$ than at $\mathrm{pH} 6.08 \pm 0.02$. Table 3 summarizes the model parameters and their fitting performance (f-value). An f-value lower than the F-value table of the degrees of freedom of the model and the data support the proper fitting performance of the model. The stability of apigeninidin could adequately be described by three parameters, i.e. the natural logarithm of the initial concentration $\left(\ln C_{0}\right)$, the inverse of the kinetic rate constant $(\delta)$ and the shape parameter $(\beta)$. The natural logarithm of the initial concentration $\left(\ln \mathrm{C}_{0}\right)$ is higher at $\mathrm{pH} 6.08 \pm 0.02$ (5.12) than at $\mathrm{pH} 9.03 \pm 0.04$ (4.96). Moreover, the inverse of the kinetic rate constant $(\delta)$ is lower at $\mathrm{pH} 6.08 \pm 0.02$ (41.2) than at $\mathrm{pH}$ $9.03 \pm 0.04$ (164.2). Nevertheless, the shape parameter $(\beta)$ was not different at $\mathrm{pH} 6.08 \pm 0.02$ (0.62) and $\mathrm{pH} 9.03 \pm 0.04(0.63)$. The $\mathrm{pH}$ change and the heat treatment affected the initial concentration and the kinetic rate constant. Although apigeninidin is stable at $\mathrm{pH} 6-9$, its stability can apparently be affected by the time of exposure at alkaline $\mathrm{pH}$. Indeed, storage at $4{ }^{\circ} \mathrm{C}$ overnight (i.e. for $18 \mathrm{~h}$ ) affected $\ln \mathrm{C}_{0}$ at $\mathrm{pH} 9.03 \pm 0.04$. The lower degradation rate of apigeninidin at $\mathrm{pH} 9.03 \pm 0.04$ is in contrast to the degradation of most anthocyanins during heat treatment (Matsufuji et al., 2007). Few aglycone anthocyanins like apigeninidin showed such stability at high pH (Matsufuji et al., 2007).

Table 1 shows the TCD, PC and \%PC stability of the watery extract of sorghum biocolorant during a heat treatment $\left(65^{\circ} \mathrm{C}\right)$ at $\mathrm{pH} 6.08 \pm 0.02$ and $9.03 \pm 0.04$. The higher TCD and PC of quinoidal apigeninidin at $\mathrm{pH} 9.03 \pm 0.04$ compared to $\mathrm{pH} 6.08 \pm 0.02$ suggest (i) a higher colour intensity and (ii) a better resistance to bleaching, respectively. The higher colour density of the SAWE is used by processors to efficiently colour the surface of wagashi, a soft cheese of West Africa, at room temperature. During the heat treatment, the TCD was stable at $\mathrm{pH}$ $6.08 \pm 0.02$ whereas it decreased at $\mathrm{pH} 9.03 \pm 0.04$. In addition, the $\mathrm{PC}$ and the $\% \mathrm{PC}$ of the extracts (at pH 6.08 and 9.03) increased during heating. Therefore, heat treatment (i) affected the density of the colour at $\mathrm{pH} 9.03 \pm 0.04$ and (ii) increased the amount of compounds resistant to bleaching at $\mathrm{pH} 6.08 \pm 0.02$ and $9.03 \pm 0.04$. The increased PC suggests the formation of new compounds reacting with sulphite. In addition, the chemical oxidation in heat treated polyphenol-containing foods could enhance the antioxidant activity (Nicoli et al., 1999). Consequently, the increase of newly formed antioxidant reactive fragments might protect apigeninidin from the oxidizing activity of sulphite, leading to the increasing PC. More research is needed to identify the reactive fragments formed during heat treatment of apigeninidin extracts and how they enhance the resistance to bleaching. 


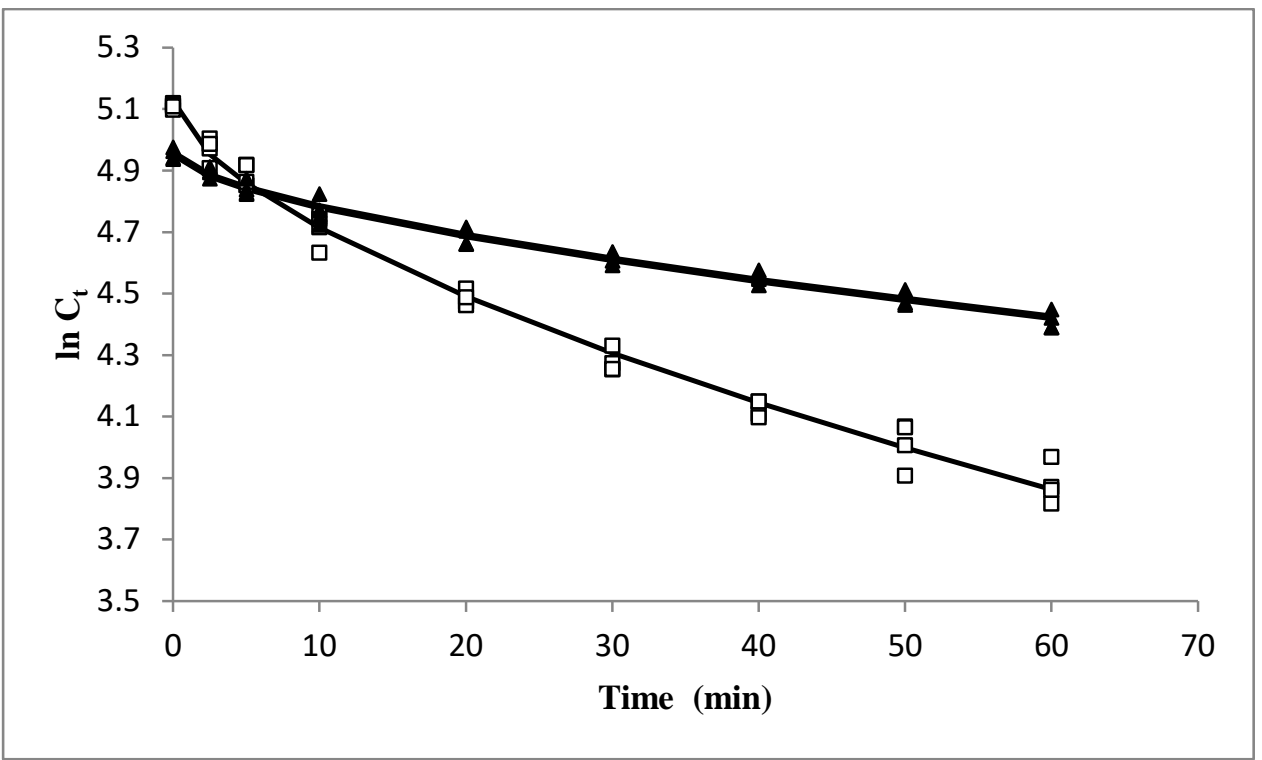

Figure 5. Kinetic degradation at $65^{\circ} \mathrm{C}$ of apigeninidin in dye sorghum extract at pH $6.08(\square)$ and $9.03(\boldsymbol{\Delta})$ and the fitted data with using the Weibull model.

Table 3. Values of parameters estimated with the Weibull model

\begin{tabular}{lllll}
\hline $\begin{array}{l}\text { Extract } \\
\mathbf{p H}\end{array}$ & $\begin{array}{l}\text { Estimated } \\
\text { parameters }\end{array}$ & Mean & $\begin{array}{l}\text { Standard } \\
\text { error }\end{array}$ & $\begin{array}{l}\text { f-value of } \\
\text { the } \\
\text { model* }\end{array}$ \\
& & & & \\
\hline 6.08 & $\ln \mathrm{C}_{0}$ & 5.12 & 0.02 & $1.0^{* *}$ \\
& $\delta$ & 41.19 & 1.60 & \\
\hline 9.03 & $\beta$ & 0.62 & 0.03 & \\
& $\ln \mathrm{C}_{0}$ & 4.96 & 0.01 & $0.9 * *$ \\
& $\delta$ & 164.2 & 10.02 & \\
\hline & $\beta$ & 0.63 & 0.04 & \\
\hline
\end{tabular}

$*_{\mathrm{f}-\text { value }}=\mathrm{MSE}_{\text {model }} / \mathrm{MSE}_{\text {data }}$

**f-value $<$ F-value table of the degrees of freedom of the model and the data (1.87) means Weibull model described the observed values well 


\section{Perspectives for the food industry}

The alkaline treatment of sorghum leaf sheaths increased the release of the apigeninidin from the raw material and could thus be considered as an alternative and selective extraction method for 3-deoxyanthocyanidins (Akogou et al., 2018). The effect of the high $\mathrm{pH}$ on the apigeninidin concentration confirms extraction at $\mathrm{pH}$ around 8.7-9 to be the optimum to extract apigeninidin without the risk of degradation into phenolic acids. Considering the increased loss of apigeninidin at a decreasing $\mathrm{pH}$ using a heat treatment for food processing (Geera et al., 2012), severe heat treatments should be applied in the $\mathrm{pH}$ range 7-9 to minimise loss of apigeninidin. The SAWE was more resistant to nucleophilic attack due to blanching.

\section{CONCLUSION}

Watery extracts from dye sorghum leaf sheaths demonstrated good stability (i) to processing conditions, including severe heat treatments, (ii) at pH 6-10 and (iii) to light exposure. Storage temperature affects stability; refrigerated conditions are to be preferred. Furthermore, the quinoidal base of apigeninidin (at $\mathrm{pH}$ 9) had a higher colour intensity and a better resistance to heat treatment. The loss of the net charge caused loss of solubility, leading to apigeninidin precipitation. Controlled acidification of alkaline extracts can be used to precipitate apigeninidin from watery extracts. Further research is needed to investigate (a) the control of the loss of net charge in acidic watery extracts of apigeninidin, (b) the identification of new antioxidant reactive fragments from apigeninidin degradation.

\section{ACKNOWLEDGEMENTS}

This research is funded by the Netherlands Organization for International Cooperation in Higher Education (Grant award CF8188/2012). The authors thank Matthijs Dekker for assistance with data analysis. 


\section{REFERENCES}

Adinsi, L., Vieira-Dalode, G., Akissoe, N., Anihouvi, V., Mestres, C., Jacobs, A., Dlamini, N., Pallet, D., \& Hounhouigan, D. J. (2014). Processing and quality attributes of gowé: A malted and fermented cereal-based beverage from Benin. Food Chain, 4 (2), 171-183.

Akogou, F. U. G., Kayodé, A. P. P., den Besten, H. M. W., \& Linnemann, A. R. (2018). Extraction methods and food uses of a natural red colorant from dye sorghum. Journal of the Science of Food and Agriculture, 98, 361-368.

Alighourchi, H., \& Barzegar, M. (2009). Some physicochemical characteristics and degradation kinetic of anthocyanin of reconstituted pomegranate juice during storage. Journal of Food Engineering, 90 (2), 179-185.

Awika, J. M., Rooney, L. W., \& Waniska, R. D. (2004). Properties of 3-deoxyanthocyanins from sorghum. Journal of Agricultural and Food Chemistry, 52 (14), 4388-4394.

Baublis, A., Spomer, A., \& Berber-Jiménez, M. D. (1994). Anthocyanin pigments: comparison of extract stability. Journal of Food Science, 59 (6), 1219-1221.

Brouillard, R., (1982). Chemical structure of anthocyanins. In: Anthocyanins as food colors, P. Markakis, (Ed.). Academic Press.

Brouillard, R., Iacobucci, G. A., \& Sweeny, J. G. (1982). Chemistry of anthocyanin pigments. 9. UV-visible spectrophotometric determination of the acidity constants of apigeninidin and three related 3-deoxyflavylium salts. Journal of the American Chemical Society, 104 (26), 7585-7590.

Cao, S., Liu, L., Pan, S., Lu, Q., \& Xu, X. (2008). A comparison of two determination methods for studying degradation kinetics of the major anthocyanins from blood orange. Journal of Agricultural and Food Chemistry, 57 (1), 245-249.

den Besten, H. M. W., Mataragas, M., Moezelaar, R., Abee, T., \& Zwietering, M. H. (2006). Quantification of the effects of salt stress and physiological state on thermotolerance of Bacillus cereus ATCC 10987 and ATCC 14579. Applied and Environmental Microbiology, 72 (9), 5884-5894.

Dyrby, M., Westergaard, N., \& Stapelfeldt, H. (2001). Light and heat sensitivity of red cabbage extract in soft drink model systems. Food Chemistry, 72 (4), 431-437.

Geera, B., Ojwang, L. O., \& Awika, J. M. (2012). New highly stable dimeric 3deoxyanthocyanidin pigments from Sorghum bicolor leaf sheath. Journal of Food Science, 77 (5), C566-C572. 
Hiemori, M., Koh, E., \& Mitchell, A. E. (2009). Influence of cooking on anthocyanins in black rice (Oryza sativa L. japonica var. SBR). Journal of Agricultural and Food Chemistry, 57 (5), 1908-1914.

Kayodé, A. P. P., Bara, C. A., Dalodé-Vieira, G., Linnemann, A. R., \& Nout, M. J. R. (2012). Extraction of antioxidant pigments from dye sorghum leaf sheaths. LWT-Food Science and Technology, 46 (1), 49-55.

Kırca, A., \& Cemeroğlu, B. (2003). Degradation kinetics of anthocyanins in blood orange juice and concentrate. Food Chemistry, 81 (4), 583-587.

Kokkaew, H., Srithanyarat, N., \& Pitirit, T. (2015). Optimization of anthocyanin and effects of acidulants on phytochemicals and antioxidant activities in purple waxy corn cookies. AsiaPacific Journal of Science and Technology, 20 (1), 75-90.

Locatelli, M., Carlucci, G., Genovese, S., Curini, M., \& Epifano, F. (2011). Use of HPLC in the determination of the molar absorptivity of $4^{\prime}$-geranyloxyferulic acid and boropinic acid. Chromatographia, 73 (9-10), 889-896.

Madodé, Y. E. E., 2012. Keeping local foods on the menu: A study on the small-scale processing of cowpea. Wageningen, the Netherlands: Wageningen University.

Matsufuji, H., Kido, H., Misawa, H., Yaguchi, J., Otsuki, T., Chino, M., Takeda, M., \& Yamagata, K. (2007). Stability to light, heat, and hydrogen peroxide at different $\mathrm{pH}$ values and DPPH radical scavenging activity of acylated anthocyanins from red radish extract. Journal of Agricultural and Food Chemistry, 55 (9), 3692-3701.

Mazza, G., \& Brouillard, R. (1987). Recent developments in the stabilization of anthocyanins in food products. Food Chemistry, 25 (3), 207-225.

Nicoli, M. C., Anese, M., \& Parpinel, M. (1999). Influence of processing on the antioxidant properties of fruit and vegetables. Trends in Food Science \& Technology, 10 (3), 94-100.

Ojwang, L., \& Awika, J. M. (2008). Effect of pyruvic acid and ascorbic acid on stability of 3deoxyanthocyanidins. Journal of the Science of Food and Agriculture, 88 (11), 1987-1996.

Ojwang, L. O., \& Awika, J. M. (2010). Stability of apigeninidin and its methoxylated derivatives in the presence of sulfites. Journal of Agricultural and Food Chemistry, 58 (16), 9077-9082.

Torskangerpoll, K., \& Andersen, Ø. M. (2005). Colour stability of anthocyanins in aqueous solutions at various pH values. Food Chemistry, 89 (3), 427-440.

Turfan, Ö., Türkyılmaz, M., Yemiş, O., \& Özkan, M. (2011). Anthocyanin and colour changes during processing of pomegranate (Punica granatum L., cv. Hicaznar) juice from sacs and whole fruit. Food Chemistry, 129 (4), 1644-1651. 
Wallace, T. C., \& Giusti, M. M. (2015). Anthocyanins. Advances in Nutrition: An International Review Journal, 6 (5), 620-622.

Yang, L., Dykes, L., \& Awika, J. M. (2014). Thermal stability of 3-deoxyanthocyanidin pigments. Food Chemistry, 160, 246-254. 


\section{Chapter 5}

Application of apigeninidin-rich red sorghum biocolorant in a fermented food improves product quality*

F. U. G. Akogou, T. S. Canoy, A. P. P. Kayodé, H. M. W. den Besten, A. R. Linnemann, V. Fogliano 


\begin{abstract}
Background: The "clean label" trend is pushing the food industry to replace synthetic colorants by plant-based colorants. However, technological efficacy and undesirable side effects restrict the use of plant-based colorants in industrial applications. This research studied the production of fermented maize dough coloured by apigeninidin-rich red sorghum biocolorant, as practiced for centuries in West Africa, as a model to assess the impact of the biocolorant on nutritional and sensorial quality of foods.

Results: A 3-day fermentation of a dyed maize dough (containing $327 \mu \mathrm{g} \mathrm{g}^{-1} \mathrm{DM}$ of apigeninidin) by Pichia kudriavzevii and Lactobacillus fermentum led to a degradation of $69 \%$ of the apigeninidin content, causing a clearly visible colour difference $\left(\Delta \mathrm{E}^{*}{ }_{00} 17.4\right)$. The antioxidant activity of fermented dyed dough increased by $51 \%$ compared to fermented nondyed dough. However, the phytate dephosphorylation and volatile compound concentrations were lower in dyed dough than in non-dyed dough. This suggests a lower mineral solubility and change in the sensory quality of fermented dyed dough.

Conclusion: Apigeninidin extract from sorghum leaf sheaths proved to be a bioactive red biocolorant with potential in fermented foods. The formation of new antioxidant compounds needs further investigation as does the impact on the development of volatile compounds.
\end{abstract}

Keywords: apigeninidin, maize dough, fermentation, antioxidant activity, nutritional quality, volatile compounds. 


\section{INTRODUCTION}

Colour has been added to food for centuries (Downham \& Collins, 2000). Synthetic and natural colorants share 40 and $31 \%$ of the colorant market, respectively (Mapari et al., 2010). However, the demand for natural colorants is predicted to increase with an annual rate of 5$10 \%$ (Downham \& Collins, 2000). This increasing interest for natural colorants is supported by (a) legislation in favour of replacement of synthetic colorants because of increasing concerns about their safety and (b) consumer awareness of the safety risks associated to synthetic colorants (Mapari et al., 2010). The anthocyanins represent the most diverse group of plant-based colorants with more than 600 molecular structures identified to date (Konczak \& Zhang, 2004). In addition to their colouring properties, anthocyanins are of interest to the food industry because of their health-supporting properties (i.e. their activity as antioxidants) (Konczak \& Zhang, 2004). However, their low stability to processing conditions (e.g. conditions of middle acid and neutral $\mathrm{pH}$, high temperature, light and oxygen) generally limits their use as food colorants (Markakis, 1982).

In West Africa, breakfast usually consists of fermented, cereal-based porridges that are prepared from maize or sorghum sourdough (Nout, 2009). The fermentation of the sourdough involves lactic bacteria such as Lactobacillus fermentum and yeasts including Saccharomyces cerevisiae and Pichia kudriavzevii (Nout, 2009). The sourdough fermentation increases the amounts of fermentable carbohydrates, amino acids, small peptides and soluble minerals. Furthermore, several groups of volatile compounds (i.e. hydrocarbons, esters, carbonyls, alcohols and acids) are produced by the microbial conversion of amino acids and polyphenols, providing a characteristic contribution to the sensory profile of the final product (Nout, 2009; Ferri et al., 2016).

Despite these positive aspects, the nutritional profile of cereal-based products is far from complete and the combination with ingredients rich in proteins, essential fats and/or phytochemicals is common practice (Nout, 2009; Sui et al., 2016). In West Africa, a red sour maize porridge, obtained by incorporation of a red extract from dye sorghum leaf sheaths, is produced and consumed by both infants and adults (Akogou et al., 2018b). Red cereal porridges are preferred by consumers in Benin because of their sensorial and alleged nutritional properties (Kayodé et al., 2005). The dye sorghum extract contains apigeninidin, which is a 3-deoxyanthocyanidin with potential applications in the food industry because of its good stability to $\mathrm{pH}$, heat treatment and bleaching (Ojwang \& Awika, 2010; Yang et al., 2014). In addition, the antioxidant activity of the apigeninidin-rich extract suggests health 
benefits for consumers (Kayodé et al., 2011). Bai et al. (2014) and Izquierdo-Cañas et al. (2016) suggested that the fermentation of an anthocyanin-rich food matrix with only lactic acid bacteria (e.g. L. fermentum) leads to (a) decarboxylation of phenolic acids and (b) conversion of anthocyanins into pyrano-anthocyanins and vinylphenol adducts. The use of yeasts (e.g. P. kudriavzevii) is recommended for efficient anthocyanin degradation (Ho et al., 2014). The Beninese sourdough process involving both yeast (e.g. P. kudriavzevii) and lactic acid bacteria (L. fermentum) provides a food model suitable to investigate the stability of apigeninidin and its potential added value to fermented starchy foods. This study investigated apigeninidin stability, antioxidant activity, sugar content, phytate, oxalate, phosphate and volatile organic compounds (VOCs) during fermentation of maize dough enriched with red apigeninidin-rich extract from sorghum leaf sheaths as a contribution to the potential use of this biocolorant in industrial applications.

\section{MATERIAL AND METHODS}

\section{Maize processing}

White maize grains were bought from the local market of Abomey-Calavi, Benin. The maize grains were cleaned to remove stones, washed in demi-water and dried in an oven (Venticell 55, MMM Medcenter Einrichtungen, Germany) at $60{ }^{\circ} \mathrm{C}$ during 24 h. A mill (RotorMill Pulvrisette-14) equipped with a $0.2 \mathrm{~mm}$ sieve was used to mill the grain into flour.

\section{Extraction of biocolorant from sorghum leaf sheaths}

The alkaline extraction method reported by Akogou et al. (2018b) was used to obtain a sorghum watery extract. Briefly, dry sorghum leaf sheaths $(11.1 \mathrm{~g})$ were suspended in demiwater $(1000 \mathrm{~mL})$ alkalinised by kanwu $(1.5 \mathrm{~g})$, an alkaline rock salt. The mixture was stirred for $20 \mathrm{~min}$ at room temperature to obtain sorghum watery extract. The liquid and solid particles were separated using a $0.3 \mathrm{~mm}$ sieve. The watery extract was centrifuged at 3000 rpm at $4{ }^{\circ} \mathrm{C}$ during 30 min to obtain the supernatant. The control was a solution of kanwu (1.5 $\left.\mathrm{g} \mathrm{L}^{-1}\right)$ of which the $\mathrm{pH}$ was adjusted to 8.7 with citric acid $(1 \mathrm{M})$ to match the $\mathrm{pH}$ of the sorghum watery extract. A $0.2 \mu \mathrm{m}$ AcroVac Filter Unit (VWR, Netherlands) was used to filtersterilise both the sorghum watery extract and the control solution of kanwu.

\section{Inoculum preparation}

The lactobacilli (i.e. L. fermentum) and yeast (i.e. Candida krusei also known as $P$. kudriavzevii) with the highest distribution frequency during maize dough fermentation were 
selected to prepare the incocula (Hounhouigan et al., 1993; Greppi et al., 2013). The strains of P. kudriavzevii and L. fermentum were provided by the Laboratory of Food Microbiology, Wageningen University, the Netherlands. One loop-full of P. kudriavzevii and L. fermentum kept at $-80^{\circ} \mathrm{C}$ were inoculated on Malt Extract (ME) and Man Rogosa Sharpe (MRS) agar plates, respectively. The inoculated ME and MRS agar plates were incubated at $30{ }^{\circ} \mathrm{C}$ in an incubator (VENTI-Line VL 115, VWR) under (a) aerobic conditions for $24 \mathrm{~h}$ and (b) microaerophilic conditions for $48 \mathrm{~h}$, respectively. One colony of each P. kudriavzevii and $L$. fermentum was transferred to $9 \mathrm{~mL}$ of ME broth and MRS broth, respectively. The tubes were incubated at $37^{\circ} \mathrm{C}$ for $18 \mathrm{~h}$. Next the concentrations of the inocula were determined by plate counting, resulting in $6.8 \mathrm{log} \mathrm{cfu} \mathrm{mL}^{-1}$ and $8.6 \mathrm{log} \mathrm{cfu} \mathrm{mL}^{-1}$ for P. kudriavzevii and $L$. fermentum, respectively.

\section{Inoculation and fermentation}

The dyed dough (DD) containing 6 and $4 \log \mathrm{cfu}^{-1}$ of L. fermentum and P. kudriavzevii, respectively, was prepared by mixing $112 \mathrm{~mL}$ of sterile sorghum biocolorant, $0.56 \mathrm{~mL}$ of $L$. fermentum inoculum, $0.36 \mathrm{~mL}$ of $P$. kudriavzevii inoculum and $112 \mathrm{~g}$ of maize flour. The same procedure was used to prepare the non-dyed dough (NDD), except that the sterile sorghum biocolorant was replaced by the sterile control solution of kanwu. The initial concentrations of L. fermentum and P. kudriavzevii in maize dough corresponded to the initial concentration of lactobacilli and yeast in homemade maize dough in Benin (Hounhouigan et al., 1994). The samples of DD and NDD were transferred to sterile boxes. Five samples of DD and NDD were prepared for sampling at $0,5,24,48$ and $72 \mathrm{~h}$ of fermentation, and placed at $30{ }^{\circ} \mathrm{C}$ in an incubator (VENTI-Line VL 115, VWR). pH, colour and volatile organic compounds (VOCs) were measured on the fresh DD and NDD at each time point. Contents of apigeninidin, sugar, phytate, oxalate and phosphate as well as antioxidant activity were measured on freeze-dried DD and NDD. All experiments (including inoculum preparation, inoculation and fermentation) were performed in duplicate.

\section{Analyses}

pH and colour

The $\mathrm{pH}$ values of $30 \mathrm{~g}$ of fresh DD and NDD were measured with a $\mathrm{pH}$ meter (pHenomenal pH 1100L,VWR International), calibrated with two buffers of $\mathrm{pH} 7$ and $\mathrm{pH} 4$ (Merck, Germany). Colour $\left(L^{*}, a^{*}, b^{*}\right)$ of the fresh DD and NDD was measured with a spectrocolorimeter (ColorFlex, HunterLab) (illuminant D65). The $L^{*}, a^{*}$ and $b^{*}$ values were 
used to calculate the chroma $\left(C^{*}\right)$ and the hue $\left(h^{\circ}\right)$. In addition, the total colour difference $\left(\Delta \mathrm{E}^{*}{ }_{00}\right)$ of $\mathrm{DD}$ and NDD was calculated using the time zero colour as reference for DD and NDD, respectively (Sharma et al., 2005).

\section{Phenolics and apigeninidin}

Extraction of phenolic compounds was according to the method of Kayodé et al. (2011). Freeze-dried samples $(100 \mathrm{mg})$ were added to $\mathrm{HCl} / \mathrm{methanol}(1 \% \mathrm{v} / \mathrm{v})(3 \mathrm{~mL})$ and stirred for one hour at room temperature, followed by centrifugation at 5,000 $\times g$ during $10 \mathrm{~min}$ and collection of the supernatant. The pellet was extracted again using the same conditions. Apigeninidin was measured in the resulting $6 \mathrm{~mL}$ extract. Before HPLC injection, each extract was mixed with an equal volume of formic acid (10\%) in milli-Q water and filtered with $0.2 \mu \mathrm{m}$ RC filters. Apigeninidin was measured with an Ultimate $3000 \mathrm{RS}$ High Performance Liquid Chromatography (HPLC) system, equipped with a Diode Array Detector DAD-3000 RS (Thermo Scientific Dionex), a quaternary pump LPG- 3000 RS (Thermo Scientific Dionex) and a Polaris C18-A column $(150 \times 4.6 \mathrm{~mm}$, Varian). Formic acid $(10 \%)$ in milli-Q water (A) and methanol (100\%) (B) were used as eluents. The flow rate was $1 \mathrm{~mL}$ $\mathrm{min}^{-1}$ with a total elution programme of $35 \mathrm{~min}$, as follows: $0-20 \mathrm{~min}$ from $5 \% \mathrm{~B}$ to $60 \% \mathrm{~B}$; $20-25$ min from $60 \% \mathrm{~B}$ to $100 \% \mathrm{~B} ; 25-30 \mathrm{~min} 100 \% \mathrm{~B} ; 30-31 \mathrm{~min}$ from $100 \% \mathrm{~B}$ to $5 \% \mathrm{~B}$; 31-35 $\min 5 \%$ B. The UV-spectra were recorded from 220-700 nm. Apigeninidin (Extrasynthese, France) was used as standard for identification and quantification at $480 \mathrm{~nm}$.

\section{Sugars}

Freeze-dried DD and NDD samples $(100 \mathrm{mg})$ were added to ethanol $/ \mathrm{milli}-\mathrm{Q}$ water $(50 / 50 \mathrm{v} / \mathrm{v})$ $(40 \mathrm{~mL})$ and vortexed during $1 \mathrm{~min}$. After incubation at $50{ }^{\circ} \mathrm{C}$ during $1 \mathrm{~h}$ in a water bath, the mixture was centrifuged for $10 \mathrm{~min}$ at $3000 \mathrm{rpm}$ and the supernatant collected. The supernatant was filtered with a $0.2 \mathrm{RC}$ filter before identification and quantification of sugars using HPLC with D-glucose (Merck, Germany) as standard. The HLPC system was equipped with an Evaporative Light Scattering (ELS) detector PL-ELS 2100 (Polymer Laboratories), a pump and a Grace prevail carbohydrate ES $5 \mu \mathrm{m}, 250 \times 4.6 \mathrm{~mm}$ column (Grace, Columbia, MD, USA). The elution programme was isocratic with acetonitrile (A) (75\%) and milli-Q water (B) $(25 \%)$ and a total running time of $30 \mathrm{~min}$. The flow rate was $0.8 \mathrm{~mL} \mathrm{~min}^{-1}$.

\section{Phytate, phosphate and oxalate}

Concentrations of phytate, phosphate and oxalate were analysed by HPLC with a conductivity detection according to Bentsink et al. (2003) with some modifications. To $20 \mathrm{mg}$ of freeze- 
dried DD and NDD, $1 \mathrm{~mL}$ of $0.5 \mathrm{~mol} \mathrm{~L}^{-1} \mathrm{HCl}$ containing $50 \mathrm{mg} \mathrm{L}^{-1}$ trans-aconitate (Fluka) was added. The mixture was extracted at $100{ }^{\circ} \mathrm{C}$ for $15 \mathrm{~min}$. After centrifugation at 13,300 rpm for $5 \mathrm{~min}$, the supernatant was collected and diluted 5 times with milli-Q water. The diluted supernatant was injected into a Dionex ICS2500 system with an AS11-HC column and AG11-HC guard column, set at a flow time of $5 \mathrm{~mL} \mathrm{~min}^{-1}$. The following eluent and elution times were used: 25-100 mM NaOH from 0-15 min; $500 \mathrm{mM} \mathrm{NaOH}$ from 15-20 min to rinse the column and $25 \mathrm{mM} \mathrm{NaOH}$ from 20-35 min to equilibrate the column. Data were collected from the HPLC as amounts of anions in $\mathrm{mg} \mathrm{L}^{-1}$. Trans-aconitic acid (Fulka), citric acid monohydrate (BDH), sodium phosphate dibasic (Merck, Germany) and phytic acid sodium salt hydrate (Sigma, Germany) were used as standards for identification and quantification.

\section{Antioxidant activity}

The QUENCHER method was used to determine the total antioxidant activity of the solid material without extraction (Serpen et al., 2008). A stock solution of DPPH was prepared by dissolving $10 \mathrm{mg}$ DPPH (Sigma, Germany) in $250 \mathrm{~mL}$ of ethanol (Merck, Germany) (50 \%). The solution was incubated for $23 \mathrm{~h}$ and its absorbance at $525 \mathrm{~nm}$ was $0.5-0.8$ before use. Freeze-dried samples of DD and NDD were diluted with cellulose at 1:1 ratio. In $5 \mathrm{~mL}$ Eppendorf tubes, 5, 10, 20 and $40 \mathrm{mg}$ of the diluted freeze-dried DD and NDD were prepared.

Trolox (Sigma Aldrich, The Netherlands) was used as standard. Standard solutions of 4, 10, 20 and $30 \mathrm{mM}$ of Trolox in ethanol (100\%) were made. The tubes for the calibration curve were prepared by adding $10 \mu \mathrm{L}$ of $4,10,20$ and $30 \mathrm{mM}$ of Trolox to $10 \mathrm{mg}$ of cellulose. The blank was prepared by adding $10 \mu \mathrm{L}$ of ethanol (100\%) to $10 \mathrm{mg}$ of cellulose. Four tubes of blank were prepared.

A volume of $5 \mathrm{~mL}$ of DPPH solution was added to the tubes containing samples, calibration points, and blank. The tubes were incubated for $100 \mathrm{~min}$ at room temperature and stirred with a shaker (Heidolph Multi Reax, Germany). Subsequently, the tubes were centrifuged for 5 min at $9,000 \times g$ and the absorbance was measured at $525 \mathrm{~nm}$ with an UV-VIS spectrophotometer (Cary WinUV 50 Varian, USA). The antioxidant activity in freeze-dried DD and NDD was expressed in mmol g ${ }^{-1}$ Trolox equivalent using formula (1).

Antioxidant activity $\left(\mathrm{mmol} \mathrm{g}^{-1}\right)=\frac{\operatorname{Trolox}_{50}(\mathrm{mmol})}{\text { Sample }_{50}(\mathrm{mg})} \times 10^{3}$

where: 
Trolox ${ }_{50}=$ concentration of Trolox $(\mathrm{mmol})$ at which the initial blank absorbance is reduced by half

Sample ${ }_{50}=$ amount of sample $(\mathrm{mg})$ at which the initial blank absorbance is reduced by half

$10^{3}=$ conversion factor from $\mathrm{mmol} \mathrm{mg}^{-1}$ to $\mathrm{mmol} \mathrm{g}^{-1}$

\section{Volatile compounds}

Volatile compounds of DD and NDD at $0 \mathrm{~h}$ and $72 \mathrm{~h}$ of fermentation were determined by headspace measurements. DD and NDD samples $(0.5 \mathrm{~g})$ were transferred to $500 \mathrm{~mL}$ bottles. The volatile profile was analysed with a PTR-ToF-MS 8000 instrument (Ionicon Analytik $\mathrm{GmbH}$, Innsbruck, Austria) with the following instrumental conditions for the proton transfer reaction: drift voltage $999.0 \mathrm{~V}$, drift temperature $59.9{ }^{\circ} \mathrm{C}$, and pressure drift $3.8 \mathrm{mbar}$ affording an E/N value of $134 \mathrm{Td}$. Sampling was performed with a flow of $52 \mathrm{~mL} \mathrm{~min}^{-1}$. The mass $(\mathrm{m} / \mathrm{z})$ was recorded from 20 to 300 . The acquisition rate was 1 spectrum $\mathrm{s}^{-1}$. A total run of $60 \mathrm{~s}$ was applied to each sample as follows: $0-10 \mathrm{~s}$ to collect the spectrum of the room and $10-60 \mathrm{~s}$ to collect the spectrum of the samples by connecting the bottle containing the samples to the inlet. The dead time correction, the internal calibration of the mass spectra, the peak extraction, and the calculations of the volatile compounds from the peaks were according to Cappellin et al. (2011) and Lindinger \& Jordan (1998). The concentrations are reported in ppbv (parts per billion by volume). The averages of the cycles 0-10 and 40-50 were calculated and used as the VOCs of the blank and the samples, respectively. For each sample, the blank was subtracted.

\section{Data analysis}

Data are expressed as mean \pm standard deviation. Data were analysed with SPSS Statistical software version 23. One way analysis of variance (ANOVA) with Tukey's HSD post-hoc was used for normally distributed data with homogeneity of variance (i.e. for phosphate, phytate and citrate). When the conditions for the application of ANOVA were not fulfilled (i.e. for $\mathrm{pH}, L^{*}, C^{*}, h^{\circ}$, apigeninidin, oxalate, antioxidant activity and sugars), the non-parametric, Kruskal-Wallis and Mann-Whitney pair-wise comparison were used. Analysis of variance was performed to select the masses that explain the differences in the aroma profiles of the DD and the NDD before and after fermentation. 


\section{RESULTS AND DISCUSSION}

Figure 1 presents the apigeninidin content of DD during fermentation. After 3 days of fermentation, $69 \%$ of the apigeninidin content was degraded. Apigeninidin is usually described as stable to most common processing conditions ( $\mathrm{pH}$, temperature and bleaching) (Ojwang \& Awika, 2010; Yang et al., 2014). Therefore, the pH drop cannot explain the extensive decrease in apigeninidin observed during dough fermentation in the present study. The action of microorganisms (L. fermentum and P. kudriavzevii) used as inoculum apparently affected the apigeninidin content (Gänzle, 2014). Indeed, yeast and lactic acid bacteria can affect the anthocyanin concentration. Anthocyanin could be absorbed by yeast, based on the hydrophobic interaction between the anthocyanins and the yeast cell walls (Morata et al., 2003). The less hydroxylated anthocyanins, such as the 3-deoxyanthocyanidins from sorghum (e.g. apigeninidin), could be then absorbed and degraded. In addition, the enzymatic activity of lactic acid bacteria (e.g. decarboxylase and reductase) on anthocyanins could have contributed to the degradation of apigeninidin into phenolic acids and volatile organic compounds (VOCs) (Svensson et al., 2010; Gänzle, 2014).

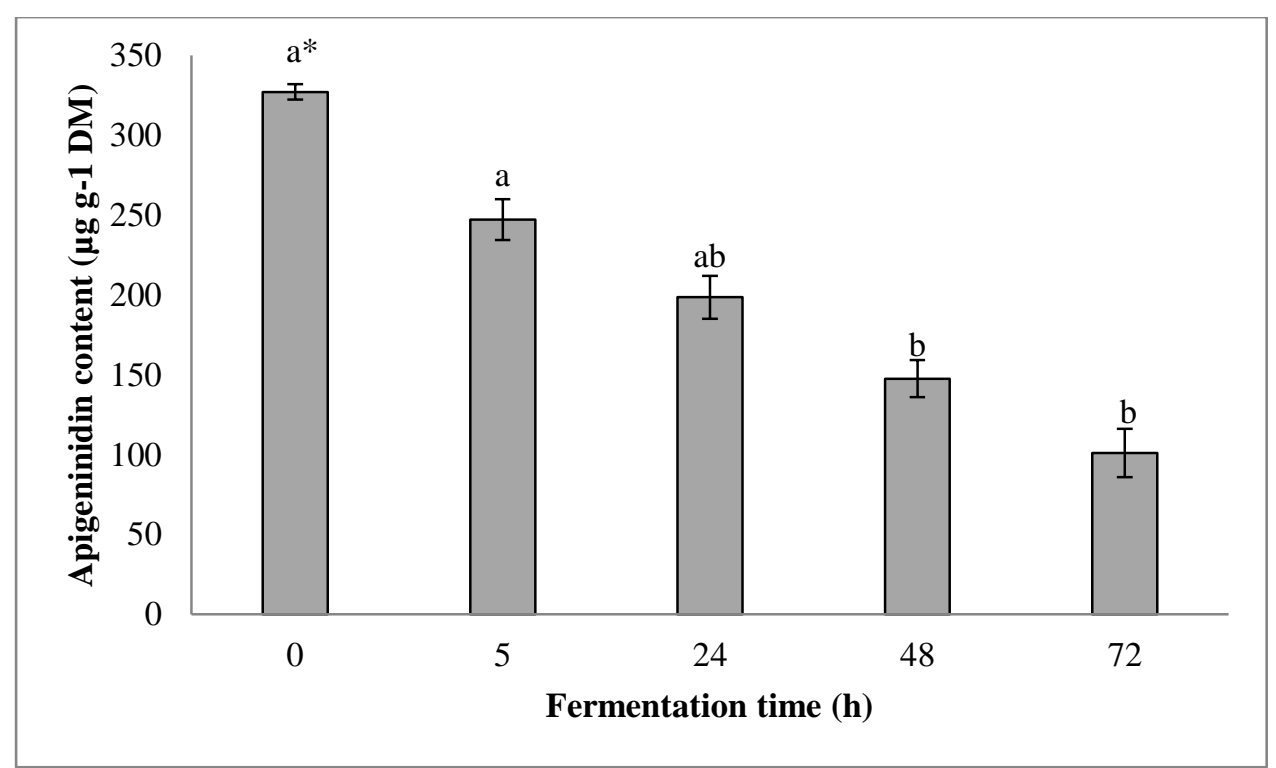

*Bars with the same letters are not significantly different at $5 \%$

Figure 1. The apigeninidin content during fermentation of dyed maize dough.

Table 1 presents the total colour difference $\left(\Delta \mathrm{E}^{*}{ }_{00}\right)$, the Lightness $\left(L^{*}\right)$, the chroma $\left(C^{*}\right)$ and the hue $\left(h^{\circ}\right)$ of the DD and NDD during fermentation. The $\Delta \mathrm{E}^{*}{ }_{00}$ of DD and NDD increased during fermentation. The $\Delta \mathrm{E}^{*}{ }_{00}$ is commonly classified as small (when $\Delta \mathrm{E}^{*}{ }_{00}<1.5$ ), distinct $\left(1.5<\Delta \mathrm{E}^{*}{ }_{00}<3\right)$ or large $\left(\Delta \mathrm{E}^{*}{ }_{00}>3\right)$ (Adekunte et al., 2010). From 0 to $24 \mathrm{~h}$ of fermentation, 
$\Delta \mathrm{E}^{*}{ }_{00}$ of NDD was small, but $>3$ at 48 and $72 \mathrm{~h}$ of fermentation. Indeed, the difference in the colour of the NDD could visually be perceived from $48 \mathrm{~h}$ of fermentation onwards. On the contrary, $\Delta \mathrm{E}^{*}{ }_{00}$ of DD was $>3$ already after $5 \mathrm{~h}$ of fermentation and increased to 17.4 at $72 \mathrm{~h}$ of fermentation. The $L^{*}$ values increased during the fermentation of the NDD whereas the $C^{*}$ and $h^{\circ}$ values remained stable. On the contrary, the $L^{*}$ and $h^{\circ}$ values of the DD increased during fermentation whereas the $C^{*}$ values remained stable. From the above data, the colour change of DD and NDD after fermentation can be described as a visible change from red to orange-red and from yellow to light yellow, respectively. The decrease in apigeninidin content and the production of organic acids (e.g. lactic acid) affecting the $\mathrm{pH}$ and the colour intensity both contributed to the loss of total colour density during the fermentation (Akogou et al., 2018a).

Table 1. Colour of dyed and non-dyed maize dough during fermentation.

\begin{tabular}{llllll}
\hline Samples & Time (h) & $\Delta \mathbf{E}^{*}{ }^{* 00}$ & $\boldsymbol{L}^{*}$ & $\boldsymbol{C}^{*}$ & $\boldsymbol{h}^{\circ}$ \\
\hline Non-dyed dough & 0 & $0 \pm 0$ & $75.0 \pm 0.7 \mathrm{~b}$ & $15.4 \pm 0.6 \mathrm{~b}$ & $86.9 \pm 0.2 \mathrm{c}$ \\
& 5 & $0.8 \pm 0.6$ & $74.6 \pm 0.4 \mathrm{~b}$ & $14.8 \pm 0.5 \mathrm{~b}$ & $87.9 \pm 0.0 \mathrm{c}$ \\
& 24 & $0.9 \pm 0.4$ & $74.2 \pm 0.0 \mathrm{~b}$ & $15.0 \pm 0.0 \mathrm{~b}$ & $88.8 \pm 0.1 \mathrm{c}$ \\
& 48 & $4.5 \pm 1.1$ & $81.3 \pm 0.9 \mathrm{a}$ & $15.3 \pm 0.4 \mathrm{~b}$ & $87.9 \pm 0.5 \mathrm{c}$ \\
& 72 & $5.3 \pm 0.4$ & $82.5 \pm 0.2 \mathrm{a}$ & $16.1 \pm 0.0 \mathrm{~b}$ & $88.0 \pm 0.1 \mathrm{c}$ \\
\hline Dyed dough & 0 & $0 \pm 0$ & $44.0 \pm 1.0 \mathrm{~d}$ & $35.3 \pm 0.2 \mathrm{a}$ & $32.5 \pm 0.2 \mathrm{a}$ \\
& 5 & $5.0 \pm 2.0$ & $48.4 \pm 1.2 \mathrm{~d}$ & $32.6 \pm 0.8 \mathrm{a}$ & $37.7 \pm 0.6 \mathrm{a}$ \\
& 24 & $7.9 \pm 0.8$ & $49.8 \pm 0.2 \mathrm{~d}$ & $34.9 \pm 0.3 \mathrm{a}$ & $45.0 \pm 0.3 \mathrm{~b}$ \\
& 48 & $15.1 \pm 0.1$ & $57.8 \pm 0.9 \mathrm{c}$ & $36.7 \pm 0.5 \mathrm{a}$ & $46.3 \pm 0.6 \mathrm{~b}$ \\
& 72 & $17.1 \pm 1.5$ & $59.7 \pm 0.5 \mathrm{c}$ & $35.4 \pm 0.3 \mathrm{a}$ & $48.4 \pm 0.4 \mathrm{~b}$ \\
\hline
\end{tabular}

Mean \pm standard deviation; Total colour difference compared to colour at 0 h: small $\left(\Delta \mathrm{E}^{*} 00<1.5\right)$, distinct $\left(1.5<\Delta \mathrm{E}^{*} 00<3\right)$ or large $\left(\Delta \mathrm{E}^{*} 00>3\right)$; values in a column with the same letter are not significantly different at $5 \%$.

Figure 2 shows the antioxidant activity during fermentation. Fermentation of DD from 24 to $72 \mathrm{~h}$ increased the antioxidant activity by $20 \%$ to $51 \%$, respectively, compared to NDD. In cereal foods, up to $70 \%$ of the antioxidant components are insoluble and cannot be measured in a solvent extract (Serpen et al., 2008). The QUENCHER method allows a direct antioxidant measurement of the food matrix and provides more accurate data on the antioxidant activity of a food matrix (Serpen et al., 2008). 


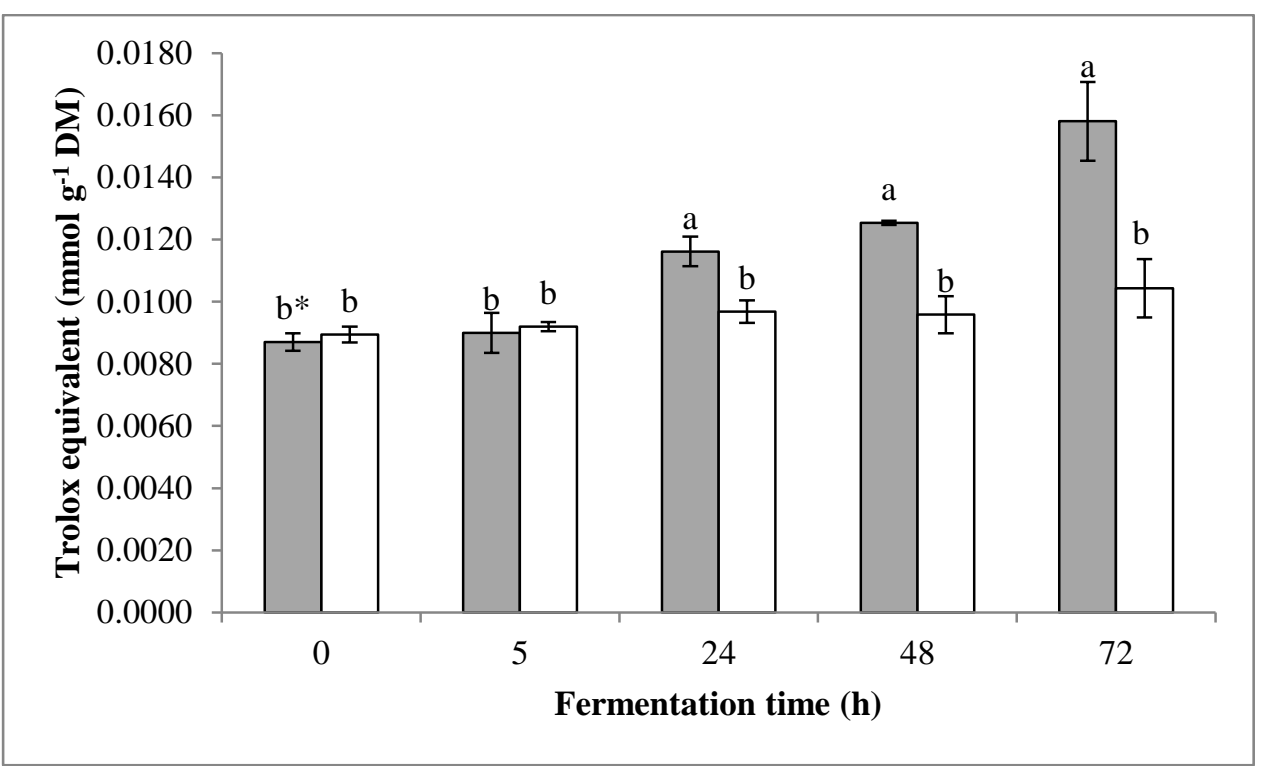

*Bars with the same letters are not significantly different at 5\%

Figure 2. Antioxidant activity of dyed ( $\square$ ) and non-dyed ( $\square$ ) maize dough during fermentation.

Clearly, the incorporation of apigeninidin-rich sorghum extract in the maize dough followed by fermentation improved this functional product quality aspect. Apigeninidin is reported to possess significant antioxidant activity (Kayodé et al., 2011). However, no difference in antioxidant activity was observed between DD and NDD at time zero nor during the first $5 \mathrm{~h}$ of fermentation. Boveris et al. (2001) suggested a minimum dose-response of $200 \mu \mathrm{g} \mathrm{mL}^{-1}$ of apigeninidin for scavenger activity towards hydroxyl radicals, quinones and/or nitric oxide. The application of apigeninidin at a concentration up to $327 \mu \mathrm{g} \mathrm{g}^{-1} \mathrm{DM}$ in dough might be below the minimum dose-response for scavenger activity in solid foods (e.g. dough). Furthermore, the decrease of the apigeninidin content and the simultaneous increase in antioxidant activity after a minimum fermentation of $24 \mathrm{~h}$ suggest the formation of new antioxidant compounds.

Table 2 presents the changes in the $\mathrm{pH}$, sugar content, mineral chelating compounds (phytate and oxalate) and phosphate contents in the DD and NDD during fermentation. The highest $\mathrm{pH}$ drop and sugar increase were recorded between 5 and $24 \mathrm{~h}$ of fermentation in both doughs (Weaver \& Kannan, 2002; Israr et al., 2017). The oxalate content remained stable in both doughs. On the contrary, the phytate content (IP6) was higher in DD $\left(8.4 \mathrm{mg} \mathrm{g}^{-1}\right)$ than in NDD (7.5 $\left.\mathrm{mg} \mathrm{g}^{-1}\right)$ at $0 \mathrm{~h}$ (Weaver \& Kannan, 2002). This suggests that the application of sorghum biocolorant increased the phytate content of the dough. Nevertheless, fermentation efficiently 
lowered the phytate content from 7.5-8.4 $\mathrm{mg} \mathrm{g}^{-1}$ to $6.1-6.3 \mathrm{mg} \mathrm{g}^{-1}$ in both doughs after $72 \mathrm{~h}$ of fermentation. The phosphate content increased accordingly from $0.3-0.4 \mathrm{mg} \mathrm{g}^{-1}$ to $0.9 \mathrm{mg} \mathrm{g}^{-1}$ after $72 \mathrm{~h}$ of fermentation as a result of phytate degradation into its lower polymers. Furthermore, the Pearson correlation $\left(\mathrm{r}^{2}=0.87\right)$ between phytate degradation and phosphate formation during the fermentation was significant at 0.01 level. Phytate and oxalate are common mineral chelating compounds of importance in cereals and affect the solubility of essential minerals in the human gut (Weaver \& Kannan, 2002; Israr et al., 2017). However, the complexation of oxalate with cations reduces the solubility of oxalate in the gut and is therefore considered as a strategy to reduce the absorption of oxalate, thereby preventing the formation of kidney stones (Israr et al., 2017). The decrease of the molar concentration of phytate and the increase of the molar concentration of phosphate were 0.003 and $0.006 \mathrm{mmol}$ $\mathrm{g}^{-1}$, respectively, in DD and 0.002 and $0.007 \mathrm{mmol} \mathrm{g}^{-1}$, respectively, in the NDD. For a one unit decrease of the phosphorylation level, the molar concentration of degraded phytate should be equal to the molar concentration of formed phosphate. A higher ratio of the molar concentration of degraded phytate to the molar concentration of formed phosphate suggests a higher level of dephosphorylation. The ratios of the molar concentration of degraded phytate to the molar concentration of formed phosphate were 2 and 3.5 in DD and NDD, respectively. A minimum phytate dephosphorylation level of 2 (from IP6 to IP4) could increase mineral solubility (Weaver \& Kannan, 2002). However, the mineral solubility in DD might be lower than in NDD. Phytate dephosphorylation would increase the cation availability, which in turn could bind oxalate, reducing its solubility (Weaver \& Kannan, 2002; Israr et al., 2017). However, the lower dephosphorylation of phytate in DD suggested (a) less soluble minerals and (b) more soluble oxalate, increasing the risk of kidney stones in comparison to NDD.

Figure 3 presents the clustering of the volatiles in the doughs as determined by PTR-MS at 0 and $72 \mathrm{~h}$ of fermentation. A clear distinction is visible between the volatile profiles of DD and NDD and their fermented doughs. This demonstrates the development of volatile compounds during fermentation of DD and NDD. However, volatile concentrations differed in DD and NDD after fermentation as the two groups (i.e. fermented DD and fermented NDD) are separate. 
Table 2. Physico-chemical characteristics of dyed and non-dyed maize dough during fermentation

\begin{tabular}{|c|c|c|c|c|c|c|}
\hline Samples & Time (h) & pH & $\begin{array}{l}\text { Sugars } \\
\left(\mathrm{mg} \mathrm{g}^{-1} \mathrm{DM}\right)\end{array}$ & $\begin{array}{l}\text { Phytate } \\
\left(\mathrm{mg} \mathrm{g}^{-1} \mathrm{DM}\right)\end{array}$ & $\begin{array}{l}\text { Phosphate } \\
\left(\mathrm{mg} \mathrm{g}^{-1} \mathrm{DM}\right)\end{array}$ & $\begin{array}{l}\text { Oxalate } \\
\left(\mathrm{mg} \mathrm{g}^{-1} \mathrm{DM}\right)\end{array}$ \\
\hline \multirow[t]{5}{*}{ Non-dyed dough } & 0 & $6.3 \pm 0.1 \mathrm{a}$ & nd & $7.5 \pm 0.2 b$ & $0.3 \pm 0.01 \mathrm{e}$ & $0.3 \pm 0.02 \mathrm{a}$ \\
\hline & 5 & $6.3 \pm 0.1 \mathrm{a}$ & nd & $7.6 \pm 0.4 \mathrm{~b}$ & $0.5 \pm 0.03 \mathrm{~d}$ & $0.3 \pm 0.01 \mathrm{a}$ \\
\hline & 24 & $4.3 \pm 0.1 \mathrm{~b}$ & $58.7 \pm 0.7$ a & $6.7 \pm 0.5 \mathrm{~cd}$ & $0.7 \pm 0.01 \mathrm{c}$ & $0.3 \pm 0.01 \mathrm{a}$ \\
\hline & 48 & $4.3 \pm 0.0 \mathrm{~b}$ & $61.7 \pm 1.5 \mathrm{a}$ & $6.5 \pm 0.1 \mathrm{~cd}$ & $0.8 \pm 0.00 \mathrm{a}$ & $0.3 \pm 0.00 \mathrm{a}$ \\
\hline & 72 & $4.3 \pm 0.0 \mathrm{~b}$ & $50.4 \pm 2.4 \mathrm{~b}$ & $6.3 \pm 0.4 \mathrm{~d}$ & $0.9 \pm 0.00 \mathrm{a}$ & $0.4 \pm 0.00 \mathrm{a}$ \\
\hline \multirow[t]{5}{*}{ Dyed dough } & 0 & $6.3 \pm 0.1 \mathrm{a}$ & nd & $8.4 \pm 0.5 \mathrm{a}$ & $0.4 \pm 0.01 \mathrm{e}$ & $0.3 \pm 0.00 \mathrm{a}$ \\
\hline & 5 & $6.3 \pm 0.1 \mathrm{a}$ & nd & $7.8 \pm 0.2 \mathrm{ab}$ & $0.4 \pm 0.03 \mathrm{~d}$ & $0.3 \pm 0.01 \mathrm{a}$ \\
\hline & 24 & $4.3 \pm 0.1 \mathrm{~b}$ & $57.1 \pm 1.0 \mathrm{a}$ & $7.2 \pm 0.1 \mathrm{~b}$ & $0.6 \pm 0.00 \mathrm{c}$ & $0.3 \pm 0.01 \mathrm{a}$ \\
\hline & 48 & $4.2 \pm 0.1 \mathrm{~b}$ & $58.3 \pm 2.0 \mathrm{a}$ & $6.2 \pm 0.1 \mathrm{~d}$ & $0.73 \pm 0.01 \mathrm{~b}$ & $0.3 \pm 0.00 \mathrm{a}$ \\
\hline & 72 & $4.1 \pm 0.0 \mathrm{~b}$ & $53.4 \pm 2.2 \mathrm{~b}$ & $6.1 \pm 0.01 \mathrm{~d}$ & $0.9 \pm 0.03 \mathrm{a}$ & $0.3 \pm 0.01 \mathrm{a}$ \\
\hline
\end{tabular}

nd: not detected

mean \pm standard deviation; values in a column with the same letter are not significantly different at $5 \%$. 


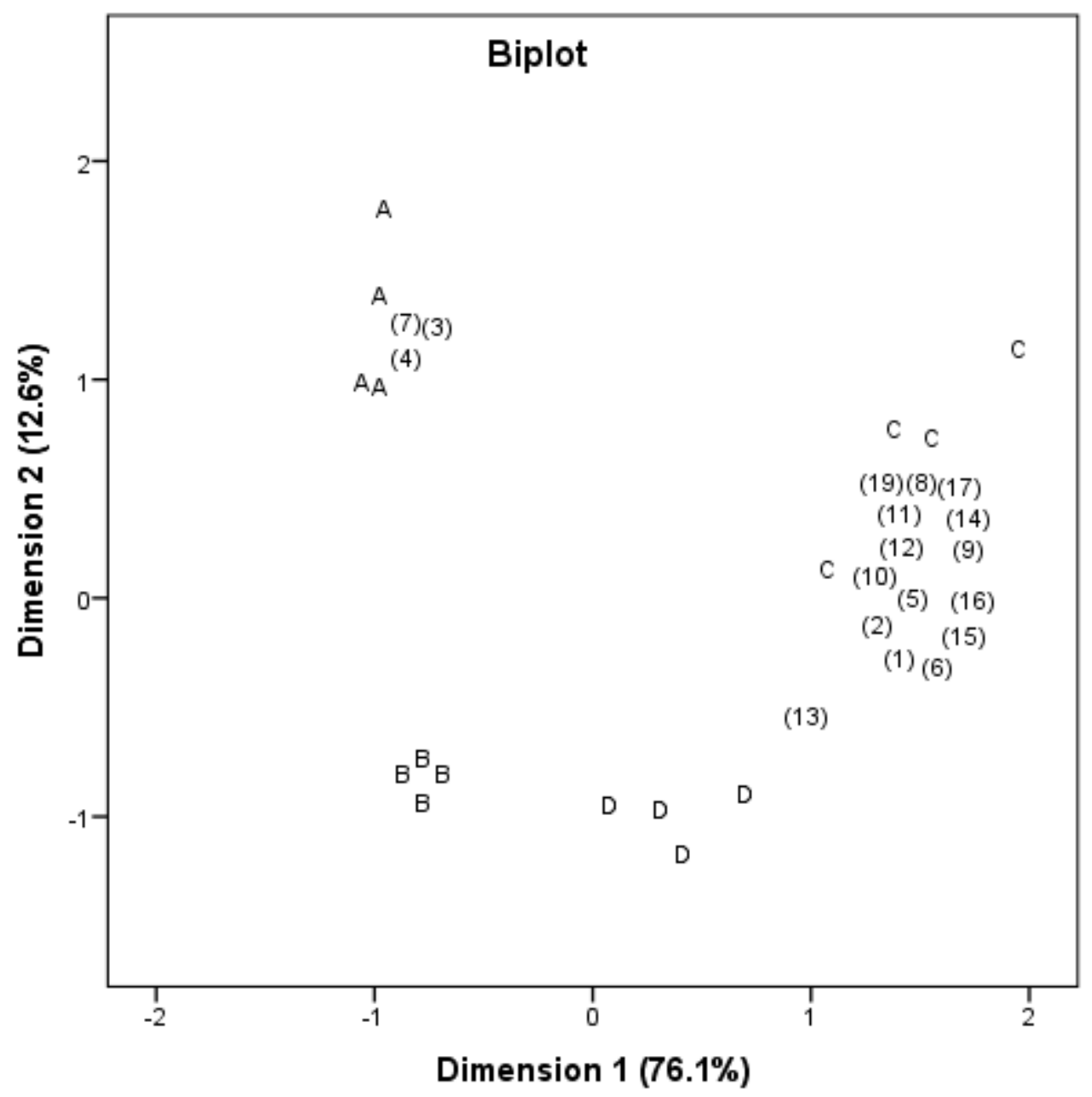

Figure 3. Normalised biplot of non-fermented doughs (A: dyed dough, B: non-dyed dough) and fermented doughs (C: non-dyed dough, D: dyed dough) on the masses (1): $\mathrm{m} / \mathrm{z} 29.039$, (2): $\mathrm{m} / \mathrm{z} 31.017$, (3) $\mathrm{m} / \mathrm{z} 33.036$, (4): $\mathrm{m} / \mathrm{z} 37.092$, (5): $\mathrm{m} / \mathrm{z} 43.019$, (6): $\mathrm{m} / \mathrm{z} 47.05$, (7): $\mathrm{m} / \mathrm{z}$ 51.044,(8): $\mathrm{m} / \mathrm{z}$ 71.048, (9) $\mathrm{m} / \mathrm{z}$ 89.06, (10): m/z 107.076, (11): $\mathrm{m} / \mathrm{z}$ 117.091, (12): $\mathrm{m} / \mathrm{z}$ 117.132, (13): m/z 121.07, (14): m/z 135.106, (15): m/z 135.147, (16): m/z 136.138,(17): m/z 163.136, (18): m/z 177.139,(19): m/z 225.267.

Table 3 presents the profile of volatile compounds contributing to the differences between the doughs, their tentative identification by exact mass and their concentration (in ppbv). Five groups of compounds (i.e. alkenes, alcohols, esters, aldehydes and acids) were tentatively identified. The application of sorghum biocolorant appears to increase the concentration of aldehyde (methyl aldehyde), alcohol (methanol) and esters in DD at $0 \mathrm{~h}$ of fermentation. The reaction of methyl radicals with the alkaline solvent could lead to the formation of methanol 
in sorghum biocolorant and subsequently to methyl aldehyde and esters (Jasper et al., 2007). However, the fermentation of DD appears to lower the amounts of the alkene (ethylene), alcohol (ethanol), aldehyde (methyl aldehyde, butenal, methyl-propanate), acid (hexanoic acid) and esters. Anthocyanins are able to affect the activity of microbiological enzymes (e.g. carbohydrate-utilising enzymes) and may contribute to the differences in the VOCs between fermented DD and fermented NDD (Johnson et al., 2013; Li et al., 2014). A difference in the food substrate (such as the concentration of anthocyanidins) could generate stress-induced damage in the microorganisms and therefore require a high amount energy (e.g. ATP) from the microorganisms (Li et al., 2014). Without an increase in the ATP, the intracellular metabolism of the microorganisms (e.g. involved in the formation of the VOCs) could be lower (Li et al., 2014). Adaptation of the intracellular metabolism by anthocyanins might be possible after a 3-day transition and under a continuous supplementation of anthocyanins ( $\mathrm{Li}$ et al., 2014). However, the fermentation time was too short for microorganisms to complete their adaptation; hence insufficient energy is presumably the main factor leading to a lower amount of VOCs (alcohol, aldehyde, acids and esters).

\section{CONCLUSION}

The application of apigeninidin-rich sorghum extract in maize dough fermented for 3 days led to the production of an orange red fermented dough with an enhanced antioxidant activity and a stable production of sugars. However, phytate dephosphorylation and the production of VOCs in the dough were affected. Further investigations are recommended on (a) the characterisation of newly formed antioxidant compounds from enzymatic degradation of apigeninidin and (b) the effect of apigeninidin on glycolytic enzyme activity and phytate dephosphorylation in relation to the applied fermentation process. 
Table 3. Tentatively identified volatile organic compounds (ppbv) of dyed and non-dyed maize dough as affected by fermentation

\begin{tabular}{|c|c|c|c|c|c|c|}
\hline \multirow{2}{*}{$\begin{array}{l}\mathbf{m} / \mathbf{z} \\
\text { measured }\end{array}$} & \multirow[t]{2}{*}{ Formula } & \multirow{2}{*}{$\begin{array}{l}\text { Tentative } \\
\text { identification }\end{array}$} & \multicolumn{2}{|l|}{ Non- fermented } & \multicolumn{2}{|l|}{ Fermented (72 h) } \\
\hline & & & Non-dyed dough & Dyed dough & Non-dyed dough & Dyed dough \\
\hline 29.039 & $\mathrm{C}_{2} \mathrm{H}_{5}^{+}$ & Ethylene & $264.3 \pm 28.8 \mathrm{c}$ & $574.9 \pm 168.2 \mathrm{c}$ & $6263.9 \pm 202.4 \mathrm{a}$ & $5468.8 \pm 382.9 \mathrm{~b}$ \\
\hline 31.017 & $\mathrm{CH}_{3} \mathrm{O}^{+}$ & Methyl aldehyde & $21.1 \pm 7.3 \mathrm{c}$ & $259.5 \pm 109.2 \mathrm{~b}$ & $1692.1 \pm 222.3 \mathrm{a}$ & $1574.7 \pm 294.7 \mathrm{a}$ \\
\hline 33.036 & $\mathrm{CH}_{5} \mathrm{O}^{+}$ & $\begin{array}{l}\text { Methanol (Yener et al., } \\
\text { 2016b) }\end{array}$ & $24702.7 \pm 3495.2 \mathrm{~b}$ & $218209.6 \pm 54144 \mathrm{a}$ & $16.0 \pm 28.7 \mathrm{c}$ & $58.6 \pm 51.0 \mathrm{c}$ \\
\hline 37.092 & n.a & n.i. & $2195.4 \pm 306.9 \mathrm{~b}$ & $73305.1 \pm 11531.7 \mathrm{a}$ & $2.2 \pm 2.5 \mathrm{c}$ & $0.8 \pm 1.7 \mathrm{c}$ \\
\hline 43.019 & $\mathrm{C}_{2} \mathrm{H}_{3} \mathrm{O}^{+}$ & Fragment / ester & $55.7 \pm 27.5 \mathrm{~d}$ & $983.6 \pm 203.1 \mathrm{c}$ & $74743.2 \pm 12411.5 \mathrm{a}$ & $41754.26 \pm 10602.4 \mathrm{~b}$ \\
\hline 47.05 & $\mathrm{C}_{2} \mathrm{H}_{7} \mathrm{O}^{+}$ & $\begin{array}{l}\text { (Farneti et al., 2015) } \\
\text { Ethanol (Capozzi et al., } \\
\text { 2016) }\end{array}$ & $2091.5 \pm 662.4 \mathrm{c}$ & $18232.6 \pm 9386 \mathrm{c}$ & $518851.6 \pm 33636.6 \mathrm{a}$ & $430576.3 \pm 48259.5 b$ \\
\hline 51.044 & n.a & n.i. & $1515.4 \pm 265.3 \mathrm{~b}$ & $13084.1 \pm 3764 \mathrm{a}$ & $5.9 \pm 1.3 \mathrm{c}$ & $10.1 \pm 2.1 \mathrm{~b}$ \\
\hline 71.048 & $\mathrm{C}_{4} \mathrm{H}_{7} \mathrm{O}^{+}$ & $\begin{array}{l}\text { Butenal / ester (Farneti } \\
\text { et al., 2015; Yener et } \\
\text { al., 2016b) }\end{array}$ & $1.8 \pm 0.5 \mathrm{c}$ & $42 \pm 37.1 \mathrm{c}$ & $8976.9 \pm 3719.7$ a & $2623.2 \pm 797.7 \mathrm{~b}$ \\
\hline 89.060 & $\mathrm{C}_{4} \mathrm{H}_{9} \mathrm{O}_{2}{ }^{+}$ & $\begin{array}{l}\text { Methyl-propanate } \\
\text { (Yener et al., 2016a) }\end{array}$ & $2.4 \pm 4.1 \mathrm{c}$ & $114.6 \pm 86.7 \mathrm{c}$ & $376885 \pm 95119.2 \mathrm{a}$ & $190002.1 \pm 42048.1 \mathrm{~b}$ \\
\hline
\end{tabular}


Table 3. Continued

\begin{tabular}{|c|c|c|c|c|c|c|}
\hline \multirow{2}{*}{$\begin{array}{l}\mathrm{m} / \mathbf{z} \\
\text { measured }\end{array}$} & \multirow[t]{2}{*}{ Formula } & \multirow{2}{*}{$\begin{array}{l}\text { Tentative } \\
\text { identification }\end{array}$} & \multicolumn{2}{|l|}{ Non- fermented } & \multicolumn{2}{|l|}{ Fermented (72 h) } \\
\hline & & & Non-dyed dough & Dyed dough & Non-dyed dough & Dyed dough \\
\hline 107.076 & n.a & n.i. & $1.1 \pm 0.5 \mathrm{c}$ & $27.7 \pm 14.3 \mathrm{c}$ & $5498.0 \pm 1536.9 \mathrm{a}$ & $2682.6 \pm 472.8 \mathrm{~b}$ \\
\hline 117.091 & $\mathrm{C}_{6} \mathrm{H}_{13} \mathrm{O}_{2}{ }^{+}$ & $\begin{array}{l}\text { Hexanoic acid / ester } \\
\text { (Capozzi et al., 2016) }\end{array}$ & $0 \pm 0 \mathrm{c}$ & $10.5 \pm 5.5 \mathrm{c}$ & $423179 \pm 143625.4 \mathrm{a}$ & $123807.8 \pm 40128.1 \mathrm{~b}$ \\
\hline 117.132 & n.a & n.i. & $0 \pm 0 \mathrm{c}$ & $13.5 \pm 6.9 \mathrm{c}$ & $131458.2 \pm 51278.1 \mathrm{a}$ & $44387.3 \pm 19957.3 \mathrm{~b}$ \\
\hline 121.07 & $\mathrm{C}_{8} \mathrm{H}_{9} \mathrm{O}^{+}$ & $\begin{array}{l}\text { Methylbenzyaldehyde- } \\
\text { coumaran (Yener et al., } \\
2016 b \text { ) }\end{array}$ & $0.1 \pm 0.1 \mathrm{c}$ & $4.8 \pm 1.9 \mathrm{c}$ & $115.0 \pm 40.1 \mathrm{~b}$ & $223.3 \pm 84.0 \mathrm{a}$ \\
\hline 135.106 & $\mathrm{C}_{6} \mathrm{H}_{15} \mathrm{O}_{3}{ }^{+}$ & n.i. & $0.2 \pm 0.2 \mathrm{~d}$ & $7.8 \pm 1.9 \mathrm{c}$ & $29082.0 \pm 8806.0 \mathrm{a}$ & $11155.9 \pm 3471.7 \mathrm{~b}$ \\
\hline 135.147 & n.a & n.i. & $0.4 \pm 0.4 \mathrm{~d}$ & $12.1 \pm 3.7 \mathrm{c}$ & $16261.4 \pm 3439.7 \mathrm{a}$ & $10657.4 \pm 3384.0 \mathrm{~b}$ \\
\hline 136.138 & n.a & n.i. & $0.0 \pm 0.0 \mathrm{~d}$ & $0.6 \pm 0.2 \mathrm{c}$ & $1331.5 \pm 331.8 \mathrm{a}$ & $779.8 \pm 247.5 \mathrm{~b}$ \\
\hline 163.136 & n.a & n.i. & $1.0 \pm 1.0 \mathrm{c}$ & $26.3 \pm 18.3 \mathrm{c}$ & $23031.1 \pm 10269.4 \mathrm{a}$ & $6287.6 \pm 2163.1 \mathrm{~b}$ \\
\hline 177.139 & n.a & n.i. & $0.0 \pm 0.1 \mathrm{c}$ & $0.8 \pm 0.3 \mathrm{c}$ & $2819.3 \pm 1306.1 \mathrm{a}$ & $665.3 \pm 300.3 \mathrm{~b}$ \\
\hline 225.267 & n.a & n.i. & $0 \pm 0 \mathrm{~d}$ & $0.9 \pm 0.2 \mathrm{c}$ & $6033.2 \pm 3921 \mathrm{a}$ & $697.6 \pm 169.7 \mathrm{~b}$ \\
\hline
\end{tabular}

n.a.: not available; n.i.: not identified

mean \pm standard deviation; values in a line with the same letter are not significantly different at $5 \%$. 


\section{ACKNOWLEDGMENTS}

This research was funded by Netherlands Fellowship Programme (Grant award CF8188/2012). Sine Yener, Valentina Acierno and Geert Meijer assisted in data analysis.

\section{ABBREVIATIONS}

DD: dyed dough

DM: dry matter

NDD: non-dyed dough

VOCs: volatile organic compounds

\section{REFERENCES}

Adekunte, A. O., Tiwari, B. K., Cullen, P. J., Scannell, A. G. M., \& O’Donnell, C. P. (2010). Effect of sonication on colour, ascorbic acid and yeast inactivation in tomato juice. Food Chemistry, 122 (3), 500-507.

Akogou, F. U. G., Kayodé, A. P. P., den Besten, H. M. W., Linnemann, A. R., \& Fogliano, V. (2018a). Effects of processing and storage on the stability of the red biocolorant apigeninidin from sorghum. LWT-Food Science and Technology, 90, 592-597.

Akogou, F. U. G., Kayodé, A. P. P., den Besten, H. M. W., \& Linnemann, A. R. (2018b). Extraction methods and food uses of a natural red colorant from dye sorghum. Journal of the Science of Food and Agriculture, 98 (1), 361-368.

Bai, Y., Findlay, B., Sanchez Maldonado, A. F., Schieber, A., Vederas, J. C., \& Gänzle, M. G. (2014). Novel pyrano and vinylphenol adducts of deoxyanthocyanidins in sorghum sourdough. Journal of Agricultural and Food Chemistry, 62 (47), 11536-11546.

Bentsink, L., Yuan, K., Koornneef, M., \& Vreugdenhil, D. (2003). The genetics of phytate and phosphate accumulation in seeds and leaves of Arabidopsis thaliana, using natural variation. Theoretical and Applied Genetics, 106 (7), 1234-1243.

Boveris, A. D., Galatro, A., Sambrotta, L., Ricco, R., Gurni, A. A., \& Puntarulo, S. (2001). Antioxidant capacity of a 3-deoxyanthocyanidin from soybean. Phytochemistry, 58 (7), 1097 1105.

Capozzi, V., Makhoul, S., Aprea, E., Romano, A., Cappellin, L., Sanchez Jimena, A., Spano, G., Gasperi, F., Scampicchio, M., \& Biasioli, F. (2016). PTR-MS characterization of VOCs 
associated with commercial aromatic bakery yeasts of wine and beer origin. Molecules, 21 (4), 483.

Cappellin, L., Biasioli, F., Granitto, P. M., Schuhfried, E., Soukoulis, C., Costa, F., Märk, T. D., \& Gasperi, F. (2011). On data analysis in PTR-TOF-MS: from raw spectra to data mining. Sensors and Actuators B-Chemical, 155 (1), 183-190.

Downham, A., \& Collins, P. (2000). Colouring our foods in the last and next millennium. International Journal of Food Science and Technology, 35 (1), 5-22.

Farneti, B., Khomenko, I., Cappellin, L., Ting, V., Romano, A., Biasioli, F., Costa, G., \& Costa, F. (2015). Comprehensive VOC profiling of an apple germplasm collection by PTRToF-MS. Metabolomics, 11 (4), 838-850.

Ferri, M., Serrazanetti, D. I., Tassoni, A., Baldissarri, M., \& Gianotti, A. (2016). Improving the functional and sensorial profile of cereal-based fermented foods by selecting Lactobacillus plantarum strains via a metabolomics approach. Food Research International, 89, Part 3, 1095-1105.

Gänzle, M. G. (2014). Enzymatic and bacterial conversions during sourdough fermentation. Food Microbiology, 37, 2-10.

Greppi, A., Rantisou, K., Padonou, W., Hounhouigan, D. J., Jespersen, L., Jakobsen, M., \& Cocolin, L. (2013). Yeast dynamics during spontaneous fermentation of mawè and tchoukoutou, two traditional products from Benin. International Journal of Food Microbiology, 165 (2), 200-207.

Ho, V. T. T., Zhao, J., \& Fleet, G. (2014). Yeasts are essential for cocoa bean fermentation. International Journal of Food Microbiology, 174, 72-87.

Hounhouigan, D. J., Nout, M. J. R., Nago, C. M., Houben, J. H., \& Rombouts, F. M. (1993). Characterization and frequency distribution of species of lactic acid bacteria involved in the processing of mawe, a fermented maize dough from Benin. International Journal of Food Microbiology, 18 (4), 279-287.

Hounhouigan, D. J., Nout, M. J. R., Nago, C. M., Houben, J. H., \& Rombouts, F. M. (1994). Microbiological changes in mawè during natural fermentation. World Journal of Microbiology and Biotechnology, 10 (4), 410-413.

Israr, B., Frazier, R. A., \& Gordon, M. H. (2017). Enzymatic hydrolysis of phytate and effects on soluble oxalate concentration in foods. Food Chemistry, 214, 208-212.

Izquierdo-Cañas, P. M., García-Romero, E., Mena-Morales, A., \& Gómez-Alonso, S. (2016). Effects of malolactic fermentation on colour stability and phenolic composition of Petit Verdot red wines. Wine Studies, 5 (1). 
Jasper, A. W., Klippenstein, S. J., Harding, L. B., \& Ruscic, B. (2007). Kinetics of the reaction of methyl radical with hydroxyl radical and methanol decomposition. Journal of Physical Chemistry A, 111 (19), 3932-3950.

Johnson, M. H., de Mejia, E. G., Fan, J., Lila, M. A., \& Yousef, G. G. (2013). Anthocyanins and proanthocyanidins from blueberry-blackberry fermented beverages inhibit markers of inflammation in macrophages and carbohydrate-utilizing enzymes in vitro. Molecular Nutrition and Food Research, 57 (7), 1182-1197.

Kayodé, A. P. P., Adegbidi, A., Hounhouigan, D. J., Linnemann, A. R., \& Nout, M. J. R. (2005). Quality of farmers' varieties of sorghum and derived foods as perceived by consumers in Benin. Ecology of Food and Nutrition, 44 (4), 271-294.

Kayodé, A. P. P., Nout, M. J. R., Linnemann, A. R., Hounhouigan, D. J., Berghofer, E., \& Siebenhandl-Ehn, S. (2011). Uncommonly high levels of 3-deoxyanthocyanidins and antioxidant capacity in the leaf sheaths of dye sorghum. Journal of Agricultural and Food Chemistry, 59 (4), 1178-1184.

Konczak, I., \& Zhang, W. (2004). Anthocyanins-more than nature's colours. Journal of Biomedicine and Biotechnology, 2004 (5), 239-240.

Li, J., Zhao, H., \& Huang, W. (2014). Mechanism of proanthocyanidins-induced alcoholic fermentation enhancement in Saccharomyces cerevisiae. Journal of Industrial Microbiology and Biotechnology, 41 (12), 1793-1802.

Lindinger, W., \& Jordan, A. (1998). Proton-transfer-reaction mass spectrometry (PTR-MS): on-line monitoring of volatile organic compounds at pptv levels. Chemical Society Reviews, 27 (5), 347-375.

Mapari, S. A., Thrane, U., \& Meyer, A. S. (2010). Fungal polyketide azaphilone pigments as future natural food colorants? Trends in Biotechnology, 28 (6), 300-307.

Markakis, P., (1982). Stability of anthocyanins in foods. In: Anthocyanins as food colors, P. Markakis, (Ed.). Academic Press, New York.

Morata, A., Gómez-Cordovés, M. C., Suberviola, J., Bartolomé, B., Colomo, B., \& Suárez, J. (2003). Adsorption of anthocyanins by yeast cell walls during the fermentation of red wines. Journal of Agricultural and Food Chemistry, 51 (14), 4084-4088.

Nout, M. J. R. (2009). Rich nutrition from the poorest-Cereal fermentations in Africa and Asia. Food Microbiology, 26 (7), 685-692.

Ojwang, L. O., \& Awika, J. M. (2010). Stability of apigeninidin and its methoxylated derivatives in the presence of sulfites. Journal of Agricultural and Food Chemistry, 58 (16), 9077-9082. 
Serpen, A., Gökmen, V., Pellegrini, N., \& Fogliano, V. (2008). Direct measurement of the total antioxidant capacity of cereal products. Journal of Cereal Science, 48 (3), 816-820.

Sharma, G., Wu, W., \& Dalal, E. N. (2005). The CIEDE2000 color-difference formula: implementation notes, supplementary test data, and mathematical observations. Color Research and Application, 30 (1), 21-30.

Sui, X., Zhang, Y., \& Zhou, W. (2016). Bread fortified with anthocyanin-rich extract from black rice as nutraceutical sources: its quality attributes and in vitro digestibility. Food Chemistry, 196, 910-916.

Svensson, L., Sekwati-Monang, B., Lutz, D. L., Schieber, A., \& Gänzle, M. G. (2010). Phenolic acids and flavonoids in nonfermented and fermented red sorghum (Sorghum bicolor (L.) Moench). Journal of Agricultural and Food Chemistry, 58 (16), 9214-9220.

Weaver, C. M., \& Kannan, S., 2002. Phytate and mineral bioavailability. In: Food phytates, R. R. Reddy and Sathe, S. K. (Eds.). pp: 211-223.

Yang, L., Dykes, L., \& Awika, J. M. (2014). Thermal stability of 3-deoxyanthocyanidin pigments. Food Chemistry, 160, 246-254.

Yener, S., Navarini, L., Lonzarich, V., Cappellin, L., Märk, T. D., Bonn, G. K., \& Biasioli, F. (2016a). Monitoring single coffee bean roasting by direct volatile compound analysis with proton transfer reaction time-of-flight mass spectrometry. Journal of Mass Spectrometry, 51 (9), 690-697.

Yener, S., Sánchez-López, J. A., Granitto, P. M., Cappellin, L., Märk, T. D., Zimmermann, R., Bonn, G. K., Yeretzian, C., \& Biasioli, F. (2016b). Rapid and direct volatile compound profiling of black and green teas (Camellia sinensis) from different countries with PTR-ToFMS. Talanta, 152, 45-53. 
Chapter 6

General discussion 



\section{INTRODUCTION}

This thesis is about a natural red colorant that is obtained from the leaf sheaths of a tropical cereal crop, namely Sorghum bicolor. This red colorant has been used for centuries in West Africa for various purposes, among which the coloration of foods. Food colour has always been important in food choice because it impacts food perception and can even be more important than flavour and texture (Burrows, 2009). Early humans commonly associated the colours blue, black and purple to inedible food and/or less appetizing food (Burrows, 2009). The importance of colour in food selection had passed through generations and established colour as a key sensorial attribute of food products (Burrows, 2009). Furthermore, in the early renaissance in Europe food colouring -in the sense of using food additives- was practised by the upper social classes and hence a sign of distinction (Burrows, 2009). This led to the belief that dark red and golden colouring provided rich blood and promoted divine solar healing, respectively (Burrows, 2009). In addition, the ancient Egyptians promoted the healing properties of colours; red colour was believed to have a positive impact on the liver and blood pressure (Singh, 2006). Nowadays, the application of colour to foods has extended largely, including the foods offered in restaurants. In fast food restaurants, for example, red is the most popular colour because of its ability to stimulate the appetite (Singh, 2006).

The global food colour market is shared by caramel (11\%), synthetic (42\%), nature identical (20\%) and natural (27\%) pigments (Downham \& Collins, 2000). The increased demand for natural colorants stimulates the growth of the global food colour market (Dabas et al., 2011). From 2000 to 2018, the global market value of natural colorants is expected to increase from 250 to 980 million of USD (Figure 1). Consumers' preference for natural ingredients in processed foods and the safety risks associated to synthetic colorants contribute to the natural trend in food colouring (Lakshmi, 2014). Nevertheless, high production costs, low tinctorial strength and low stability of natural colorants are constraining the industrial transition from synthetic to natural colorants (Sigurdson et al., 2017). Most commercial natural colorants (i.e. carotenoids, anthocyanins, betalains and chlorophylls) are extracted from plant biomass (Rodriguez-Amaya, 2016; Sigurdson et al., 2017). The production of plant biomass for colorants is costly because it needs crop management and quality assurance chains (Gebhardt, 2015). In addition, the extraction and concentration of pigments from plant biomass that usually has a low pigment content (usually less than $2 \%$ ) further increase the production costs of natural colorants (Gebhardt, 2015). Solutions explored by the food industry are (a) exploration of new botanical sources with increased pigment contents, (b) natural selection 
and breeding programmes for increased pigment contents in the raw materials and (c) innovative technologies for extraction, processing and enhanced stability (Gebhardt, 2015).

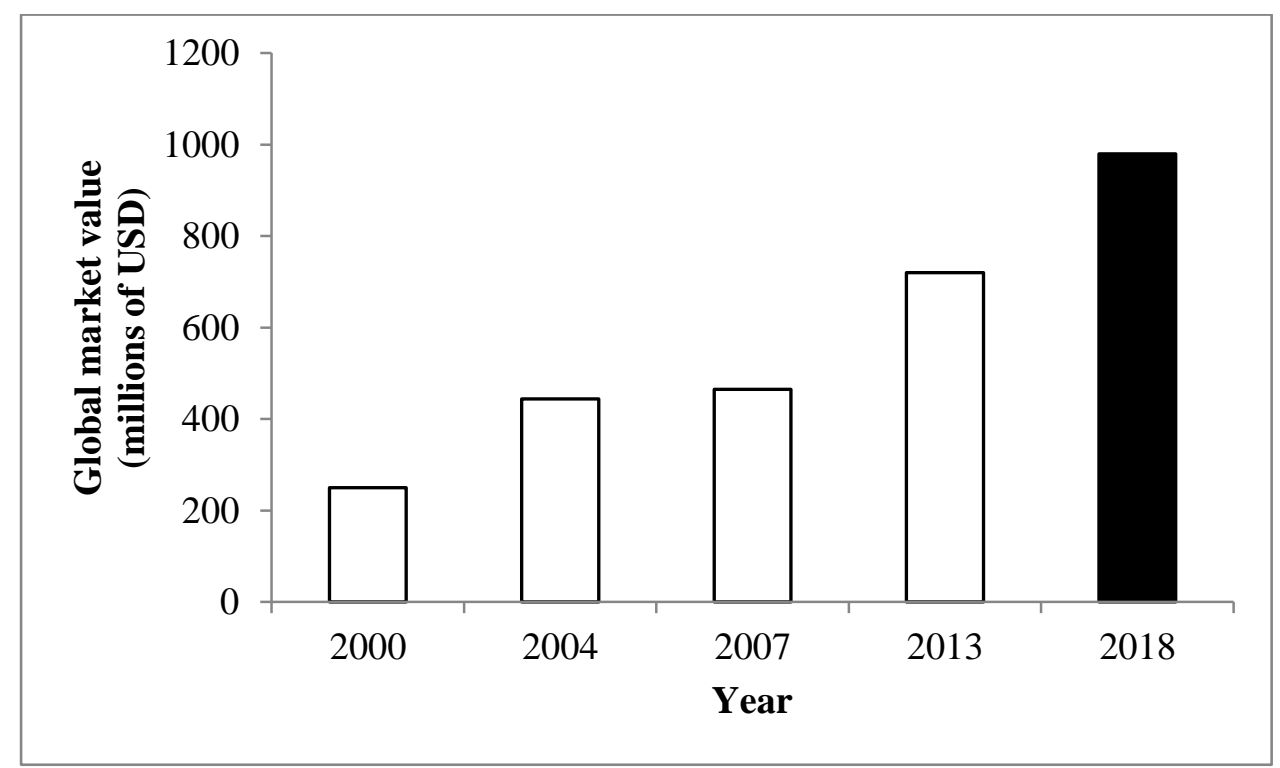

Data for 2000 (Downham \& Collins, 2000), 2004 (Mapari et al., 2010), 2007 (Mapari et al., 2010), 2013 (Pino et al., 2015) and 2018 (Pino et al., 2015).

Figure 1. Global market value of natural colorants ( $\square$ ) and its prognosis ( $\square$ ) (in millions USD)

This thesis explored the use of a new botanical source of pigments, i.e. dye sorghum leaf sheaths, alternative extraction techniques (i.e. an alkaline extraction method, hot aqueous extraction methods) and their efficiency, the stability of the sorghum biocolorant under food processing conditions and its bioactive properties in processed food. The specific objectives of this thesis were:

- To evaluate the traditional extraction methods of sorghum biocolorant with emphasis on technological and chemical considerations

- To assess the food preservative and antimicrobial properties of sorghum biocolorant using West African soft cheese (wagashi) as a food model

- To evaluate the stability of the sorghum biocolorant in relation to various food processing conditions

- To investigate the nutritional and sensorial effects of the sorghum biocolorant in a food product, namely fermented maize dough.

The dye sorghum value chain is a traditional value chain, which is not structured by formal or documented contracts (Gómez \& Ricketts, 2013). The main actors involved in the dye 
sorghum value chain are farmers, traders, retailers and users (processors and consumers). The farmers, as the first actors of the sorghum value chain, are responsible for the seed material and also for all aspects of cultivation. Commonly, part of the harvested grains, obtained from open pollination, is used as seeds for the next campaign. Once produced, the users buy the dye sorghum leaf sheaths (a) in small market places from the farmers or (b) from a network of traditional retailers (including street vendors and roadside stands) (Gómez \& Ricketts, 2013). The traditional value chain of dye sorghum suffers from limited scientific knowledge on (a) good agronomic practices to obtain high amounts of pigments in the leaf sheaths, (b) proper quality management in the supply chain, (c) optimal extraction methods and potential food applications of the biocolorants. The outcomes from this thesis that concern the extraction methods and the colour quality of the extracts, the stability to processing conditions, the bioactive properties and the potential food applications converge to strengthen the scientific basis needed to interest the food industry for using dye sorghum and to improve the value chain of dye sorghum. In addition, the evaluation of the antimicrobial properties of the sorghum biocolorant and the spectrophotometric method used to quantify anthocyanins raised some relevant discussion points on the evaluation of the antimicrobial activity of phenolic extracts and the assessment of 3-deoxyanthocyanidins by spectrophotometry, respectively.

\section{IMPLICATIONS FOR THE FARMERS AND THE SORGHUM VALUE CHAIN}

The current traditional dye sorghum value chain is characterised by the seasonal availability of dye sorghum leaf sheaths. A coordinated partnership between a relatively small number of actors (i.e. farmers, processors and food manufacturers) or a complete set of actors (including farmers, commercial agribusiness, wholesalers, local and multinational food manufacturers) could help to develop a traditional-to-modern or a modern value chain, respectively (Gómez \& Ricketts, 2013). The improvement of the dye sorghum value chain from traditional to traditional-to-modern or modern will allow farmers to work in a supply chain characterised by (a) formal or documented contracts with companies involved in ingredient and/or food production, and (b) clearly defined quality standards for the raw and processed materials, as, for instance, used by the globally operating company (Gómez \& Ricketts, 2013).

In the perspective of an improved dye sorghum value chain, the outcomes of this $\mathrm{PhD}$ research (in particular concerning the extraction methods of the biocolorant, colour stability, 
potential food applications and their functional properties) encouraged a consortium of partners consisting of farmers, a local company, Beninese and Dutch scientists to join forces for the valorisation of leaf sheaths and grains from dye sorghum to improve livelihoods in Benin with financial support of the Netherlands Organisation for Scientific Research (NWOWOTRO) (project number W 08.270.341). This project aims to (a) select elite varieties, (b) define appropriate fertilisation and cultivation techniques to guarantee maximum biocolorant concentrations and grain yield in dye sorghum, (c) optimise the extraction of the biocolorant and grain processing, and (d) assure the quality in the supply chain. This could be considered as the first step to change the dye value chain from traditional to at least traditional-modern. Furthermore, existing partnership between food ingredient manufacturers (e.g. Naturex, France) and farmers should focus on sustainability (Concibido, 2018). Sustainable agronomic practices, e.g., intercropping of dye sorghum with other crops, should be preferred to dye sorghum monoculture. Indeed, an adequate selection of crops in an intercropping system allows a better control of pests and diseases as well as prevention of soil erosion. Such practices also ensure crop diversity, thereby spreading the risk of crop failure.

\section{RELEVANCE OF THIS RESEARCH FOR A TRANSITION TO NATURAL COLORANTS IN THE FOOD INDUSTRY}

Allura red (E129 / FD\&C Red No 40), amaranth (E123 / FD\&C Red No2), Ponceau 4R (E124), erythrosine (E127 / FD\&C Red No3), carmine (E120) and paprika (E160c) are the most popular red colorants used in the food industry (Wrolstad \& Culver, 2012; Feketea \& Tsabouri, 2017). The large $\mathrm{pH}$ range of possible applications, heat and light stability support their use in large categories of products (meat, dairy, drinks, bakery, confectionary and ice products) (Feketea \& Tsabouri, 2017). This explains the reliance on synthetic colorants (Allura red, amaranth, Ponceau 4R, erythrosine) and insect-based colorants (carmine). In the context of a growing demand for natural, plant-based colorants for foods, the food industry needs to prepare an effective transition to stable natural colorants.

The content of the main pigment (i.e. apigeninidin) of the sorghum leaf sheaths ranged from $1.5-4.6 \%$ with an average of 3.1\% (Kayodé et al., 2011). With an average pigment content above $2 \%$ in the raw material, dye sorghum leaf sheaths represent a competitive source of red pigments with a good cost-in-use for extraction. Pigment extraction is a solid-liquid leaching process in which the rupture of cell walls, the release of the pigment and its transport to the 
external medium are the main mechanisms (Sivakumar et al., 2011). The rupture of the cell walls leading to the release of anthocyanins can be obtained with mechanical forces (stirring or ultrasound), enzymes and solvents (Sivakumar et al., 2011; Puri et al., 2012; Shirsath et al., 2012). Solvent extraction is usually by organic solvents and suffers from long extraction times and low quality extracts due to traces of the solvents in the product (Puri et al., 2012). This thesis provides the potential use of a non-organic solvent for the selective extraction of 3 deoxyanthocyanidins (e.g. apigeninidin). In addition, (a) the red colour of apigeninidin extract when diluted 15 times (Chapter 2) and (b) its stability to processing conditions ( $\mathrm{pH}$ and temperature) (Chapter 4) suggest a good tinctorial strength and stability as a natural red colorant. However, the leaf sheaths/solvent ratio, which was 1:90 (w/w), still needs to be improved because more than $80 \%$ of the colorant remained in the leaf sheaths after extraction (Chapter 2). Furthermore, the extraction method still needs to evolve into an environmentfriendly extraction method based on the composition of a hydrophilic solvent and a conventional alkaline salt. Efficient use of the dye leaf sheaths could lead to a lower amount of leaf sheaths in the extraction and multiple extractions on the same batch to obtain the maximum amount of pigment. In addition, the rock salt kanwu needs to be replaced by a foodgrade alkaline salt (e.g. sodium bicarbonate or sodium hydroxide) to allow its use at industrial scale.

The precipitation yield of $95 \%$ obtained from the alkaline sorghum extract and the absence of others phenolic compounds like benzoic acid and $p$-coumaric acid in the precipitate suggest a selective precipitation of anthocyanins based on loss of net charge. The precipitation of apigeninidin based on the loss of net charge is an easy, low cost and safer purification approach compared to the purification on a column, with an ionic liquid solution, an ion exchange resin, reverse osmosis and absorption (Castañeda-Ovando et al., 2009). However, the effect of a structural change (e.g. methoxylation, methylation, hydroxylation, acylation or glycosylation) of the apigeninidin on its ability to precipitate due to loss of charge at $\mathrm{pH} 5$ still needs to be investigated.

Successful substitution of a red synthetic colorant by sorghum biocolorant has to consider (a) the desired shade of red, (b) the processing conditions at stake and the colorant's interactions with other ingredients and (c) the sensorial difference perceived by consumers. The appropriate shade of red is usually related to the food matrix, the targeted market as well as the legal requirements (Downham \& Collins, 2000). For instance, food ingredients that have not been consumed by humans in the EU before 15 May 1997 are considered as novel foods 
and have to go through a safety assessment procedure (van Putten et al., 2011). The authority for Food Standards Australia New Zealand (FSANZ) is even more strict and considers nontraditional foods to Australia and New Zealand as novel foods that require safety assessment (van Putten et al., 2011). The US Food and Drug Administration (FDA) is more flexible on the issue of novel foods and considers a novel food (or substance) as generally recognised as safe (GRAS) when (a) it was consumed in the USA before 1 January 1958, or (b) scientific data or a history of consumption for food use by significant numbers of consumers can be provided (van Putten et al., 2011). The Canadian legislation considers a food as novel that should be assessed for safety only when it (a) is obtained from a process not considered as food grade, (b) has no history as safe food or (c) is derived from genetic modification technology. For new colorants like sorghum biocolorant, relevant data on (a) the food consumption of foods dyed with sorghum biocolorant in a country like Benin (General introduction) and (b) the scientific data provided in this thesis (Chapter 2-5) could support an application for quick access to the Canadian and US markets. Access to the EU and particularly to the Australian markets might require a safety assessment.

Hot processing conditions can cause the formation of an undesired brown colour in the sorghum biocolorant (Chapter 4), thus negatively affecting the colour under certain food processing conditions (i.e. certain combinations of heat treatment and $\mathrm{pH}$ ). In addition, the application of sorghum biocolorant in a fermented sourdough can affect the volatile organic compounds in the product and the dephosphorylation of phytate (Chapter 5). However, sorghum biocolorant did not affect the growth of food pathogens in broth and a model food (Chapter 3). As the colorant did not affect the growth of microorganisms, the co-use of sorghum biocolorant (as a colouring ingredient) with other functional ingredients (prebiotics and probiotics) appears to be a possibility. However, the dose effect of the sorghum biocolorant on the functional properties of probiotics needs to be explored to assess the benefits from both categories of ingredients (i.e. the antioxidant-containing colorant and the prebiotics and probiotics).

\section{RETHINKING THE CONTROL OF MICROBIAL GROWTH BY PHENOLIC COMPOUNDS}

This thesis evaluated the ability of sorghum biocolorant to hamper the growth and survival of microorganisms (bacteria and fungi) (Chapter 3). The phenolic extract contains diverse groups 
of plant extracts used for dyeing and antimicrobial purposes (Joshi et al., 2009). The antimicrobial activity of natural plant extracts usually results from the synergy of several phenolic compounds (Miyague et al., 2015), acting in different ways including (a) substrate deprivation, (b) pathogen cell wall disruption, (c) binding to cell walls (or to adhesins), (d) inactivation of essential enzymes or (e) complexation of ions to interrupt cell growth (Joshi et al., 2009). In relation to the extraction procedure used, differences were observed in the phenolic composition and the antimicrobial activities of extracts (Efstratiou et al., 2012; El Ksibi et al., 2015). In the present work, the absence of any antimicrobial activity as observed in the aqueous and alkaline extracts of sorghum biocolorant showed that high levels of apigeninidin (up to $75 \mu \mathrm{g} \mathrm{mL}^{-1}$ ) did not affect the total cell count. Small phenolic compounds (e.g. phenolic acids) could easily cross cell membranes and exert their antimicrobial activity (Cueva et al., 2010). Hydroxybenzoic acids (e.g. 4-hydroxybenzoic acid) and hydroxycinnamic acid ( $p$-coumaric acid) were used as antibiotics against Gram-negative (Escherichia coli) and Gram positive bacteria (Listeria monocytogenes) at minimum inhibitory concentrations higher than $1 \mathrm{mg} \mathrm{mL}^{-1}$ (Alves et al., 2013). The 4-hydroxybenzoic acid and $p$-coumaric acid contents in the watery extract of sorghum colorant (alkaline and hot aqueous extract) were 5.1-6.0 and 3.5-4.1 $\mu \mathrm{g} \mathrm{mL}^{-1}$, respectively (Chapter 2 and 3). Therefore it appears that the phenolic acid content in the watery extracts were too low for an antimicrobial activity. Hence, food grade extractions, other than aqueous and alkaline, should be explored to increase the extraction of phenolic acids from dye sorghum leaf sheaths. The application of less selective extraction methods (e.g. by organic solvents) could be tested to investigate the main compounds that might be co-extracted for an antimicrobial activity of sorghum biocolorant.

The control of microbial growth by ever increasing concentrations of antimicrobial compounds has thus far been the main strategy applied against food pathogens but unfortunately it also leads to increasing resistance of microorganism to antimicrobial compounds (Silva et al., 2016). The use of food phytochemicals as a means to control a variety of physiological processes of microorganisms (e.g. secretion of virulence factors and biofilm formation) is an alternative to circumvent the antimicrobial resistance of food pathogens (Truchado et al., 2012; Silva et al., 2016). As a phytochemical of Sorghum bicolor, apigeninidin should be explored for its potential action on the physiological processes of food pathogens (Truchado et al., 2012; Silva et al., 2016). The application of apigeninidin in fermented maize dough caused a lower dephosphorylation of phytate and a lower production of volatile metabolites while the glucose content remained the same as in non-dyed maize 
dough (Chapter 5). A similar ability of anthocyanins for suppressing specific gene expression (e.g. virulence) without affecting the growth and survival of the microorganism Xanthomonas oryzae has been reported by Fan et al. (2017). This property of phenolic compounds (e.g. anthocyanins) as specific gene suppressors is relevant for suppressing or attenuating physiological processes (e.g. secretion of virulence factors or biofilm formation) of Gram positive and negative food pathogens (Silva et al., 2016; Fan et al., 2017). Further work is therefore strongly recommended on the effect of apigeninidin on physiological processes of food pathogens.

\section{CONTRIBUTION OF THIS RESEARCH TO THE MEASUREMENT OF PIGMENTS BASED ON SPECTROPHOTOMETRY}

The determination of the total phenol content of different watery extracts based on their FolinCiocalteu reduction capacity appeared to be limited by the differences between the $\mathrm{pH}$ of the extracts (Chapter 2). The interference of alkaline conditions with the Folin-Ciocalteu reagent restricts the application of the total phenol assay for alkaline sorghum extracts (Blackwell et al., 2012). The use of the method to determine total phenol based on the Folin-Ciocalteu reduction assay needs to be modified to improve its efficiency. The adjustment to $\mathrm{pH} 6$ before measurement of the Folin-Ciocalteu reduction capacity of the watery extracts (alkaline, hot alkaline and hot aqueous) is suggested for determining the total phenolic content in different watery extracts.

The $\mathrm{pH}$ differential method is not suited to the monomeric content of apigeninidin-rich extracts (Chapter 4). Because of a deprotonation constant higher than the hydration constant, apigeninidin will not become colourless at any $\mathrm{pH}$. However, it precipitates at $\mathrm{pH}$ 5. This property could be used to develop an improved $\mathrm{pH}$ differential method suitable to measure apigeninidin in watery extracts. In apigeninidin-rich watery extracts, the total anthocyanins (monomeric and polymerised anthocyanins) can be measured at $\mathrm{pH} 1.0$ in a buffer as explained by Lee et al. (2005) (Chapter 4). The loss of charge at pH 5 can be applied to first precipitate the apigeninidin and the collect of the supernatant, which is free from apigeninidin. The absorbance of the apigeninidin-free supernatant in a buffer at $\mathrm{pH} 4.5$ can thus be used for the polymerised anthocyanins. The total monomeric anthocyanins (as apigeninidin equivalent) can subsequently be obtained by formula (1): 
Momomeric ACY (apigeninidin equivalent) $=\frac{\left(\mathrm{Abs}_{\alpha}-\mathrm{Abs}_{\beta}\right) \times 290.69 \times \mathrm{DF} \times 10^{3}}{\varepsilon \times \mathrm{l}}$

where $\mathrm{Abs}_{\alpha}$ : is the absorbance of the watery extract in the buffer at $\mathrm{pH} 1.0 ; \mathrm{Abs}_{\beta}$; the absorbance of the supernatant of the watery extract in a buffer at $\mathrm{pH} 4.5$ after precipitation of apigeninidin at $\mathrm{pH} 5$; 290.69: molecular weight of apigeninidin chloride $\left(\mathrm{g} \mathrm{mol}^{-1}\right)$; DF: dilution factor; $10^{3}$ : conversion factor from $\mathrm{g}$ to $\mathrm{mg} ; \varepsilon:$ molar absorptivity of apigeninidin chloride $\left(\mathrm{L} \mathrm{mol}^{-1} \mathrm{~cm}^{-1}\right)$; 1: path length.

To guarantee the success of this improved $\mathrm{pH}$ differential method, it is essential to precipitate all the apigeninidin in solution by loss of charge. The data of Chapter 4 showed a precipitation yield of $95 \%$. This indicates a pathway for an efficient $\mathrm{pH}$ differential method to measure apigeninidin in extract with spectrophotometry.

\section{CONCLUSION AND RECOMMENDATIONS}

The objective of this thesis was to investigate indigenous extraction methods of sorghum biocolorant from dye sorghum leaf sheaths, the colour properties of the biocolorant, its food applications and its bioactive properties. Alkaline extraction appeared an efficient and selective method for extracting sorghum biocolorant. Sorghum biocolorant has a sensorial function and possesses antioxidant properties but could not be associated to any antimicrobial activity. In addition, its use in food fermentation showed its ability to inhibit the metabolite production by microorganisms and the dephosphorylation of phytate. The stability of sorghum biocolorant to severe heat treatment and its good colouring properties at low concentrations contribute to its suitability as a plant-based colouring ingredient for the food industry. For successful adoption of sorghum biocolorant as a natural food colorant further research should focus on:

- $\quad$ substitution of the traditional rock salt (kanwu) by a conventional alkaline salt (e.g. sodium bicarbonate or sodium hydroxide)

- occurrence of structural changes (methoxylation, methylation, hydroxylation, acylation or glycosylation) of apigeninidin precipitated by loss of charge

- the effect of apigeninidin on properties of bioactive ingredients (e.g. probiotics)

- the effect of apigeninidin on physiological processes of food pathogens

- validation of a new $\mathrm{pH}$ differential method suitable for apigeninidin quantification

- safety assessment for an introduction on the European market. 


\section{REFERENCES}

Alves, M. J., Ferreira, I. C., Froufe, H. J., Abreu, R., Martins, A., \& Pintado, M. (2013). Antimicrobial activity of phenolic compounds identified in wild mushrooms, SAR analysis and docking studies. Journal of Applied Microbiology, 115 (2), 346-357.

Blackwell, D. L., Herald, T. J., Bean, S. R., \& Gadgil, P. (2012). Alkaline extraction of phenolic compounds from intact sorghum kernels. International Journal of Food Science and Technology, 47 (12), 2671-2675.

Burrows, J. (2009). Palette of our palates: a brief history of food coloring and its regulation. Comprehensive Reviews in Food Science and Food Safety, 8 (4), 394-408.

Castañeda-Ovando, A., de Lourdes Pacheco-Hernández, M., Páez-Hernández, M. E., Rodríguez, J. A., \& Galán-Vidal, C. A. (2009). Chemical studies of anthocyanins: A review. Food chemistry, 113 (4), 859-871.

Concibido, V., 2018. Growing source for natural colours sustainably. S. C. LLC (Ed.). https://sensientfoodcolors.com/en-us/agronomy/growing-sources-natural-colors-sustainably/.

Cueva, C., Moreno-Arribas, M. V., Martín-Álvarez, P. J., Bills, G., Vicente, M. F., Basilio, A., Rivas, C. L., Requena, T., Rodríguez, J. M., \& Bartolomé, B. (2010). Antimicrobial activity of phenolic acids against commensal, probiotic and pathogenic bacteria. Research in Microbiology, 161 (5), 372-382.

Dabas, D., Elias, R. J., Lambert, J. D., \& Ziegler, G. R. (2011). A colored avocado seed extract as a potential natural colorant. Journal of Food Science, 76 (9).

Downham, A., \& Collins, P. (2000). Colouring our foods in the last and next millennium. International Journal of Food Science and Technology, 35 (1), 5-22.

Efstratiou, E., Hussain, A. I., Nigam, P. S., Moore, J. E., Ayub, M. A., \& Rao, J. R. (2012). Antimicrobial activity of Calendula officinalis petal extracts against fungi, as well as Gramnegative and Gram-positive clinical pathogens. Complementary Therapies in Clinical Practice, 18 (3), 173-176.

El Ksibi, I., Slama, R. B., Faidi, K., Ticha, M. B., \& M’henni, M. F. (2015). Mixture approach for optimizing the recovery of colored phenolics from red pepper (Capsicum annum L.) by-products as potential source of natural dye and assessment of its antimicrobial activity. Industrial Crops and Products, 70, 34-40.

Fan, S., Tian, F., Li, J., Hutchins, W., Chen, H., Yang, F., Yuan, X., Cui, Z., Yang, C. H., \& $\mathrm{He}$, C. (2017). Identification of phenolic compounds that suppress the virulence of Xanthomonas oryzae on rice via the type III secretion system. Molecular Plant pathology, 18 
(4), 555-568.

Feketea, G., \& Tsabouri, S. (2017). Common food colorants and allergic reactions in children: myth or reality? Food Chemistry.

Gebhardt, D., 2015. Cost-in-use. S. c. LLC (Ed.). https://sensientfoodcolors.com/enus/research-development/cost-in-use/.

Gómez, M. I., \& Ricketts, K. D. (2013). Food value chain transformations in developing countries: Selected hypotheses on nutritional implications. Food Policy, 42, 139-150.

Joshi, M., Ali, S. W., Purwar, R., \& Rajendran, S. (2009). Ecofriendly antimicrobial finishing of textiles using bioactive agents based on natural products. Indian Journal of Fibre and Textile Research, 34, 295-304.

Kayodé, A. P. P., Nout, M. J. R., Linnemann, A. R., Hounhouigan, J. D., Berghofer, E., \& Siebenhandl-Ehn, S. (2011). Uncommonly high levels of 3-deoxyanthocyanidins and antioxidant capacity in the leaf sheaths of dye sorghum. Journal of Agricultural and Food Chemistry, 59 (4), 1178-1184.

Lakshmi, G. C. (2014). Food coloring: the natural way. Research Journal of Chemical Sciences, 2231 (8), 606X.

Lee, J., Durst, R. W., \& Wrolstad, R. E. (2005). Determination of total monomeric anthocyanin pigment content of fruit juices, beverages, natural colorants, and wines by the $\mathrm{pH}$ differential method: collaborative study. Journal of AOAC International, 88 (5), 1269-1278.

Mapari, S. A., Thrane, U., \& Meyer, A. S. (2010). Fungal polyketide azaphilone pigments as future natural food colorants? Trends in Biotechnology, 28 (6), 300-307.

Miyague, L., Macedo, R. E., Meca, G., Holley, R. A., \& Luciano, F. B. (2015). Combination of phenolic acids and essential oils against Listeria monocytogenes. LWT-Food Science and Technology, 64 (1), 333-336.

Pino, M. T., Mc Leod, C., Ojeda, A., Zamora, O., \& Saavedra, J., 2015. Characterization and clonal selection of Berberis microphylla G. Forst in the Chilean Patagonia Region for natural colorant purposes. In: XIV EUCARPIA Symposium on Fruit Breeding and Genetics 1172. pp: 249-254.

Puri, M., Sharma, D., \& Barrow, C. J. (2012). Enzyme-assisted extraction of bioactives from plants. Trends in Biotechnology, 30 (1), 37-44.

Rodriguez-Amaya, D. B. (2016). Natural food pigments and colorants. Current Opinion in Food Science, 7, 20-26.

Shirsath, S., Sonawane, S., \& Gogate, P. (2012). Intensification of extraction of natural products using ultrasonic irradiations - a review of current status. Chemical Engineering and 
Processing: Process Intensification, 53, 10-23.

Sigurdson, G. T., Tang, P., \& Giusti, M. M. (2017). Natural colorants: food colorants from natural sources. Annual Review of Food Science and Technology(0).

Silva, L. N., Zimmer, K. R., Macedo, A. J., \& Trentin, D. S. (2016). Plant natural products targeting bacterial virulence factors. Chemical Reviews, 116 (16), 9162-9236.

Singh, S. (2006). Impact of color on marketing. Management Decision, 44 (6), 783-789.

Sivakumar, V., Vijaeeswarri, J., \& Anna, J. L. (2011). Effective natural dye extraction from different plant materials using ultrasound. Industrial Crops and Products, 33 (1), 116-122.

Truchado, P., Tomás-Barberán, F. A., Larrosa, M., \& Allende, A. (2012). Food phytochemicals act as quorum sensing inhibitors reducing production and/or degrading autoinducers of Yersinia enterocolitica and Erwinia carotovora. Food Control, 24 (1-2), 7885.

van Putten, M. C., Kleter, G. A., Gilissen, L. J. W. J., Gremmen, B., Wichers, H. J., \& Frewer, L. J. (2011). Novel foods and allergy: Regulations and risk-benefit assessment. Food control, 22 (2), 143-157.

Wrolstad, R. E., \& Culver, C. A. (2012). Alternatives to those artificial FD\&C food colorants. Annual Review of Food Science and Technology, 3, 59-77. 
Chapter 7

Summary 

Cereals are mainly used as staple foods as well as for animal feed and biofuel. In addition, certain cereals are of interest to the food industry for more specific reasons. This is the case for dye sorghum (Sorghum bicolor), due to its ability to produce significant amounts of pigment that potentially can be used as a food colorant. The red leaf sheaths formed by dye sorghum are used in Benin to produce a red biocolorant, which is also used in for foods. The red biocolorant is a rich source of 3-deoxyanthocyanidins (i.e. apigeninidin and luteolinidin). The 3-deoxyanthocyanidins are natural pigments with (a) a narrow distribution in nature, (b) a high antioxidant activity, (c) resistance to bleaching agents, (d) resistance to ring openings during thermal treatments, (e) a better stability to $\mathrm{pH}$-induced colour changes as compared to common anthocyanins and (f) properties that inhibit the growth of cancer cells. These properties of 3-deoxyanthocyanidins contribute to colour stability during food processing. Currently, the red sorghum biocolorant is applied in Benin in cereal-, legume-, tuber- and milk-based foods. Dyed fermented cereal porridge (koko) and dyed soft cheese (wagashi) are the most popular food applications of this red biocolorant in Benin and illustrate the potential as a new stable natural colorant from sorghum that can be used in food industry. The growing interest of consumers for natural food ingredients leads to a growing demand of the food industry for natural food colorants. However, to date limited data are available on the optimal extraction conditions for sorghum biocolorant and its properties in a wider range of food products. This thesis studies the extraction conditions of biocolorant from dye sorghum leaf sheaths, evaluates its bioactive properties, as well as its nutritional and sensorial impact on food products.

The chapter 2 compares the colour and anthocyanin composition from various traditional extraction methods to determine options for improvement and use of the red biocolorant from dye sorghum in the food sector. After interviewing processors of dyed foods on the procedures of the biocolorant extraction, data were collected on the biocolorant yield and the pigment profile of the extraction methods. In addition, potential food applications were illustrated by a popular fermented porridge. Sorghum biocolorant was extracted from a batch of dye sorghum leaf sheaths with different extraction methods. The use of an alkaline rock salt (locally known as $k a n w u)$ and the temperature of the extraction water were found to be the two main parameters that differentiate the traditional extraction methods. Water, dye sorghum leaf sheaths and kanwu were mixed at the ratio 900:10.4:1.5 (w/w/w), 900:10.5:0.9 (w/w/w) and 900:11.3:0 (w/w/w) to obtain sorghum biocolorant by cool alkaline, hot alkaline and hot aqueous extraction. While the cool alkaline extraction was performed at room temperature, a gradual heating at the speed of $0.05{ }^{\circ} \mathrm{C} \mathrm{s}^{-1}$ was applied to hot (alkaline and aqueous) 
extractions until $86^{\circ} \mathrm{C}$ was reached. Cool extraction was more efficient than hot alkaline and hot aqueous extractions in taking out anthocyanins. The total anthocyanin content of the cool alkaline extract was $228.5 \mu \mathrm{g} \mathrm{mL}^{-1}$. However, the alkaline extractions (hot and cool) at $\mathrm{pH}$ 8-9 were the most efficient methods because their apigeninidin content $\left(131-152 \mu \mathrm{g} \mathrm{mL}^{-1}\right)$ was three times higher than in the aqueous extract. Nevertheless, improvement of the extraction method is necessary since the residues still contained $82.6 \%$ of anthocyanins. In Benin, sorghum biocolorant is used to colour maize-based koko, a fermented and cooked porridge. This demonstrates the ability of sorghum biocolorant to colour foods produced by fermentation and elevated temperatures.

Sorghum biocolorant is perceived by local processors of a soft cheese (called wagashi) as a means to extend the shelf-life of wagashi. If such a claim could be substantiated, it adds a valuable functional property to this natural red colorant. Hence, Chapter 3 evaluates the antimicrobial properties of dye sorghum extracts using challenge tests in broth and wagashi as a model of a popular food application. The challenge tests (a) in dyed broth with Listeria monocytogenes and Escherichia coli $\mathrm{O} 157: \mathrm{H} 7$ and (b) on dyed wagashi with fungi (i.e. Penicillium chrysogenum, Cladosporium macrocarpum) and Escherichia coli O157:H7 were used to evaluate the antimicrobial activity of the sorghum biocolorant. Additional data on the physico-chemical parameters of the dyed wagashi $(\mathrm{pH}$, dry matter and the acid value) were monitored as well. Data on the current practices of wagashi dyeing were collected as well from 90 processors. The application of sorghum biocolorant on wagashi had no inhibitory effect on the growth of fungi (Penicillium chrysogenum, Cladosporium macrocarpum) and Escherichia coli $\mathrm{O} 157: \mathrm{H} 7$ on wagashi. Furthermore, sorghum biocolorant in broth had no effect on growth of Listeria monocytogenes and Escherichia coli O157:H7. Consequently, the commonly used extracts for colouring soft West-African cheese did not show a preservative effect for the species tested. In addition, dyeing did not affect the physico-chemical properties of wagashi. Still, the red colour hampered visual detection of microbial growth, and this might clarify the preservative effect reported by users. Furthermore, the dyeing of wagashi is a means for the processors to maximise their revenues. Indeed, an increase of $11.5 \%$ of the revenues was recorded for dyed wagashi. The majority of the processors usually used a dyeing procedure with no heat treatment. This urges to raise the users' attention on the absence of a preservative effect and to also apply a heat treatment to the colorant to minimise the risk of wagashi contamination when a conservation for several days is needed. 
Chapter 4 evaluates the stability of apigeninidin, the main 3-deoxyanthocyanidin from sorghum leaf sheaths, to food processing conditions in watery extracts (alkaline and hot aqueous extracts) and in a maize porridge. The stability of apigeninidin in sorghum biocolorant extract was evaluated in (a) a pH range of 5-12, (b) heat treatments $\left(65^{\circ} \mathrm{C}, 95^{\circ} \mathrm{C}\right.$ and $121{ }^{\circ} \mathrm{C}$ ) and (c) storage conditions (light exposure, protected from light exposure and temperature). The total anthocyanins before, after the heat treatments and during storage were used to evaluate the thermal stability of sorghum biocolorant. In addition, kinetic degradation of apigeninidin at pH 6 and 9 was compared. Apigeninidin was not soluble at pH $5.04 \pm 0.02$. At $\mathrm{pH} 5.04$, the loss of net charge led to apigeninidin precipitation in the watery extract. This limits the solubility and the application of apigeninidin in acidic drinks ( $\mathrm{pH} \leq 5)$. At $\mathrm{pH}$ values higher than 6, apigeninidin was soluble with the quinoidal base as major form in solution. Apigeninidin was soluble and stable at $\mathrm{pH}$ 6-10 with increased colour density and resistance to bleaching at alkaline $\mathrm{pH}$. At pH 11 and 12, 44.1\% and 81.4\% of the apigeninidin degraded. Apigeninidin has a remarkable resistance to high $\mathrm{pH}$ and can therefore be subjected to neutral and alkaline (e.g. alkaline fermented food condiments in West Africa) treatments, contrary to most anthocyanins, which are stable in acid and middle acid conditions. The stability of apigeninidin to the heat treatments (i.e. $65^{\circ} \mathrm{C} / 30 \mathrm{~min}, 95^{\circ} \mathrm{C} / 30 \mathrm{~min}$ and $121^{\circ} \mathrm{C} / 30 \mathrm{~min}$ ) was similar at pH 7 and 8.7 with a degradation of $17-18 \%, 59-66 \%$ and $60-61 \%$ of the anthocyanins at $65{ }^{\circ} \mathrm{C} / 30 \mathrm{~min}, 95{ }^{\circ} \mathrm{C} / 30 \mathrm{~min}$ and $121{ }^{\circ} \mathrm{C} / 30 \mathrm{~min}$, respectively. The comparable percentage of degraded anthocyanins at $95{ }^{\circ} \mathrm{C}$ and $121{ }^{\circ} \mathrm{C}$ suggests the good resistance of apigeninidin to severe heat treatments. However, the resistance of apigeninidin might be affected by the $\mathrm{pH}$ of the extract. At $65^{\circ} \mathrm{C}$, the degradation rate of apigeninidin was four times lower at $\mathrm{pH} 9.03 \pm 0.04$ than at $6.08 \pm 0.02$. Storage at room temperature promoted endothermic degradation of apigeninidin. Nevertheless, photodegradation of apigeninidin was not observed during storage. In the maize porridge, thermal stability of apigeninidin and redness were similar at $\mathrm{pH} 4-6$ whereas they were higher at $\mathrm{pH} 9.03 \pm 0.04$.

Chapter 5 assesses the impact of the apigeninidin-rich sorghum biocolorant on the nutritional and sensorial quality in a fermented food. Maize dough was enriched with apigeninidin extract and fermented with Pichia kudriavzevii and Lactobacillus fermentum for 3 days at 30 ${ }^{\circ} \mathrm{C}$. The colour, glucose content, $\mathrm{pH}$, phytate dephosphorylation, oxalate degradation and formation of volatile organic compounds (VOCs) were monitored. The 3-day fermentation of the dyed maize dough (containing $327 \mu \mathrm{g} \mathrm{g}^{-1} \mathrm{DM}$ of apigeninidin) led to a degradation of $69 \%$ of the apigeninidin content. The colour of the dyed dough evolved from red to orange red with increasing lightness. The antioxidant activity of the fermented dyed dough increased 
by $51 \%$ compared to the fermented non-dyed dough. New compounds (e.g. phenolic acids) with high antioxidant activity are apparently formed during fermentation. However, phytate dephosphorylation and volatile compound concentrations (alcohol, esters, aldehydes and alkene) were lower in dyed dough than in non-dyed dough. This suggests a lower mineral solubility and change in the sensory quality in fermented dyed dough.

Chapter 6 discusses the findings of the present study and presents the contribution of this study to (a) motivate the building of a better dye sorghum value chain, (b) the transition by the food industry to natural colorants, (c) the control of microorganisms with phenolic extracts and (d) a more accurate measurement of 3-deoxyanthocyanidins by spectrophotometry. Improvement of the sorghum value chain from traditional to traditionalto-modern or modern will allow farmers to work structured on a sustainable supply chain of dye sorghum leaf sheaths. A transition by the food industry to the use of natural colorants requires raw materials with a pigment content above $2 \%$ to be competitive. With an average pigment content of $3.1 \%$, dye sorghum leaf sheaths are therefore a competitive natural biocolorant. However, successful substitution of artificial colorants by sorghum biocolorant does not solely depend on the stability of the natural colour regarding the processing condition but also on (a) regulations concerning the introduction of a new colorant on the market, (b) the colour difference due to the substitution, and (c) the consumer perception of the sensorial differences brought about by the substitution. 
Acknowledgments 



\section{Acknowledgments}

This research was carried out at the Food Quality and Design Group and the Laboratory of Food Microbiology of Wageningen University, the Netherlands and the Laboratory of Valorization and Quality Management of Food Bio-Ingredients (LaBio) of the University of Abomey-Calavi, Benin.

I am grateful to the Netherlands Organisation for International Cooperation in Higher Education (NUFFIC) that funded this research. I am also grateful to LEB fonds (Ref; 2015059A Akogou) that funded my attendance to the $8^{\text {th }}$ International Workshop on Anthocyanins (IWA), Montpellier, France.

I am grateful to Dr Judith Zwartz Foundation, Wageningen, the Netherlands and the Food Quality and Design Group for their contribution to the printing of this thesis.

I am grateful to my promotor Prof Vincenzo Fogliano and my co-promotors Prof Polycarpe Kayodé, Dr Anita Linnemann and Dr Heidy den Besten for their support and guidance during this $\mathrm{PhD}$ journey.

I thank my colleagues and technicians of Food Quality Design, Laboratory of Food Microbiology in Wageningen University and the Faculty of Agronomic Sciences in the University of Abomey Calavi for their help and collaboration. I am grateful to Charlotte van Twisk, Geert Meijer, Xandra Bakker-de Haan, Frans Lettink, Erik Meulenbroeks, Judith Wolkers-Rooijackers, Ingrid Maas, Lysanne Hoksbergen and Kimberley Boss for their assistance.

I thank all the students (Wisse de Beer, Tessa Canoy, Filiz Hazal, Anique Lemmers, Romy Vos, Nina Joustra) I supervised during my $\mathrm{PhD}$ thesis, for their helpful and appreciated contributions.

I thank the processors of dyed foods I met during my field survey in Benin for sharing their knowledge and experience on food dyeing using dye sorghum leaf sheaths.

I thank Naturex for the fruitful collaboration on the potential application of sorghum biocolorant in food industry.

I would like to use this opportunity to thank the precursors of dye sorghum research (or studies) in Benin: Dr Robert Nout and Prof. Polycarpe Kayodé. 
I would like to thank the community who welcome me in Wageningen (viz. Djalalou-Dine Arinloye, Souléimane Adékambi), to whom a stay closed during my thesis journey (viz. Dêêdi Sogbohossou, Raoul Kpégli, Waliou Yessoufou, Charles Tamou, Mikaila Issa, Hermann Tossou, Raoul Adjobo, Dorothea Wartena, Landry Fanou, Nicodème Fassinou, Harold Hounhouigan, Sylvain Dabadé, Fernande Honfo and Yann Madodé). My sincere thanks to all the members of Benin community of Wageningen I have not been able to list here.

I thank my paranymphs (James Ledo and Dêêdi Sogbohossou) for organising my defence.

I sincerely thank my mother (Caroline Soumaho), my wife (Charlotte Zoundji), my son (Oloufoumi Akogou), my daughter (Adéfoloukè Akogou) my nephew (Emmanuel Béhanzin), my brother (Donald Akogou), my sister (Lydie Akogou) for their support and love during my $\mathrm{PhD}$ journey. Please do consider this book as the reward of your love, patience and encouragements and prayers.

I owe my gratitude to my uncle Bernandin Oloudé for his greatness and for taking care of us (Donald, Lydie and I) since Dad passed away. The respect I owe you is beyond all expectations.

Folachodé Akogou

August 2018

Wageningen, the Netherlands. 
About the author 



\section{Curriculum vitae}

Folachodé Ulrich Gildas Akogou was born on August 9 ${ }^{\text {th }}, 1986$ in Pahou, Benin. He completed his primary and secondary school in Benin and obtained his baccalaureate in 2004 . From 2004 to 2009 he studied at the Faculty of Agronomic Sciences, University of Abomey Calavi and obtained the Agricultural Engineer diploma with specialisation in Nutrition and Food Science. He started in September 2012 a PhD study at Wageningen University on the Natural food colouring with dye sorghum. His expertise on natural colorant led to a collaboration with Naturex on food colouring development with sorghum biocolorant from 2016 to 2017. He has interest in developing extracts from African botany for their use as food additives. His ORCID identifier is 0000-0001-7500-5226. He can be contacted on folachodea@,gmail.com or folachodea@yahoo.fr. 


\section{Publications}

\section{Academic dissertations}

Akogou, F. U. G. (2009). Caractérisation des principales recettes à base de sorgho utilisées pour l'alimentation des enfants de 6 à 35 mois dans la commune de Natitingou au Nord-Ouest du Bénin. Agricultural Engineer Thesis. Faculty of Agronomic Sciences, University of Abomey-Calavi. 71 pages.

\section{Full papers}

Kayodé, A. P. P., Akogou, F. U. G., Hounkpatin, W. \& Hounhouigan, D. (2012). Effets des procédés de transformation sur la valeur nutritionnelle des formulations de bouillies de complément à base de sorgho. International Journal of Biological and Chemical Sciences 6, 2192-2201.

Akogou, F. U. G., Kayodé, A. P. P., den Besten, H. M. W., \& Linnemann, A. R. (2018). Extraction methods and food uses of a natural red colorant from dye sorghum. Journal of the Science of Food and Agriculture, 98, 361-368.

Akogou, F. U. G., den Besten, H. M. W., Kayodé, A. P. P., Fogliano, V., \& Linnemann, A. R. (2018). Antimicrobial evaluation of red, phytoalexin-rich sorghum food biocolorant. PloS ONE, 13 (3), e0194657.

Akogou, F. U. G., Kayodé, A. P. P., den Besten, H. M. W., Linnemann, A. R., \& Fogliano, V. (2018). Effects of processing and storage on the stability of the red biocolorant apigeninidin from sorghum. LWT-Food Science and Technology, 90, 592-597.

\section{Paper submitted}

Akogou, F. U. G., Canoy, T. S., Kayodé, A. P. P., den Besten, H. M. W., Linnemann, A. R., \& Fogliano, V. Application of apigeninidin-rich red sorghum in a fermented food improves product quality. (submitted).

\section{Abstracts}

Akogou, F. U. G., Kayodé, A. P. P. \& Hounhouigan, J. D. (2010) Effets des procédés de transformations sur la valeur nutritionnelle et les facteurs antinutritionnels des aliments de compléments à base de sorgho in: La contribution de la recherche scientifique et 
technologique à la réduction de la pauvreté en Afrique sub-saharienne. Journées Scientifiques Internationales de Lomé XIV éme édition, 25-29 octobre 2010. Lomé, Togo.

Akogou, F. U. G., Kayodé, A. P. P., den Besten, H. M. W., \& Linnemann, A. R. (2015)

Extraction and food uses of sorghum biocolorant in :The $8^{\text {th }}$ International Workshop on Anthocyanins (IWA), 16-18 Septenber 2015. Page 117. Montpellier, France.

\section{Poster}

Akogou, F. U. G., Kayodé, A. P. P., den Besten, H. M. W., \& Linnemann, A. R. (2015) Extraction and food uses of sorghum biocolorant. The $8^{\text {th }}$ International Workshop on Anthocyanins (IWA), 16-18 Septenber 2015. Montpellier, France. 


\section{Overview of completed training activities}

\section{Discipline specific activities}

Courses

Reaction kinetics in food science, VLAG, Wageningen, the Netherlands (2012)

Advanced food analysis, VLAG, Wageningen, the Netherlands (2013)

Genetics and physiology of food-associated micro-organisms, VLAG, Wageningen, the Netherlands (2013)

Multivariate analysis for food data/scientists, VLAG, Wageningen, the Netherlands (2014)

Food and biorefinery enzymology, VLAG, Wageningen, the Netherlands (2015)

Food fermentation (International Advanced Course), VLAG, Wageningen, the Netherlands (2016)

Sensory perception and food preference: Affective drivers of food choice, VLAG, Wageningen, the Netherlands (2016)

\section{Training}

Industrial extraction of sorghum colorant and its use in food matrices, Naturex, Avignon, France (2016)

Meetings

$8^{\text {th }}$ International Workshop on Anthocyanins, INRA, Montpellier, France (2015)

3rd Wageningen PhD Symposium 2016 "Diversity in Science", WPC, Wageningen, the Netherlands (2016)

Postgraduate Symposium on Food Fraud, FQD, Wageningen, the Netherlands (2016)

\section{General courses}

Bayesian Statistics, PE\&RC, Wageningen, the Netherlands (2012)

Reviewing a Scientific Paper, WGS, Wageningen, the Netherlands (2012)

Data Management, WUR library, Wageningen, the Netherlands (2012)

Information Literacy including EndNote Introduction, WUR library, Wageningen, the Netherlands (2012)

VLAG PhD week, VLAG, Baarlo, the Netherlands (2012)

Techniques for Writing and Presenting a Scientific Paper, WGS, Wageningen, the Netherlands (2013) 
Communication with the Media and the General Public, WGS, Wageningen, the Netherlands (2013)

Introduction to R for Statistical Analysis, PE\&RC, Wageningen, the Netherlands (2013)

Project and Time Management, WGS, Wageningen, the Netherlands (2013)

\section{Others activities}

VLAG PhD proposal (2012)

Master course on Food Microbiology, FHM, Wageningen, the Netherlands (2012)

PhD study tour, Thailand and Singapore (2014). 
The research described in this thesis was financially supported by the Netherlands Organization for International Cooperation in Higher Education and Research (NUFFIC) through the Netherlands Fellowship Programme (NFP)

Financial support from Dr Judith Zwartz Foundation, Wageningen, the Netherlands and Food Quality and Design, Wageningen University, the Netherlands for printing this thesis is gratefully acknowledged.

Cover design and layout by Folachodé Akogou and Fahui Liu

Printed by Digiforce / Proefschriftmaken.nl, Vianen

Copyright (C) 2018 F. U. G. Akogou 